\title{
FILOSOFIA,
}

ENGAJAMEN'TO

E SOCIEDADE

Volume II

Yuri Miguel Macedo

(Org.) 


\title{
Yuri Miguel Macedo \\ (Organizador)
}

Filosofia, Engajamento e Sociedade

\author{
Volume II
}





\title{
Yuri Miguel Macedo \\ (Organizador)
}

\section{Filosofia, Engajamento e Sociedade}

\author{
Volume II
}

Porto Seguro, BA

2020

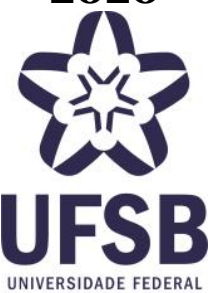

DO SUL DA BAHIA 


\section{Copyright (C) 2020 by Yuri Miguel Macedo \\ (Organizador) \\ Todos os direitos reservados}

\section{Conselho Editorial:}

Ana Helena Ithamar Passos

Eduardo David de Oliveira

Gilsilene P. P. Francischetto

Giovana A. Fazio Zanetti

Jorge Ferreira Dantas Junior

Kiusam de Oliveira

Larissa de Albuquerque Silva
Mariana Fernandes dos Santos

Pâmella Passos

Patrícia Gomes Rufino Andrade

Rita de Cássia V. da Costa

Simone Silva Alves

Sônia Guimarães

Suely Dulce de Castilho

Dados internacionais de catalogação na publicação (CIP) Universidade Federal do Sul da Bahia - Sistema de Bibliotecas

F488 Filosofia, engajamento e sociedade. Vol. 2. [livro eletrônico] / Yuri Miguel Macedo (Org.). - Porto Seguro: UFSB, 2020. $1485 \mathrm{~Kb} ; \mathrm{PDF}$

Inclui bibliografias

Vários autores

ISBN: 978-85-54252-09-0.

1. Filosofia. 2. Sociedade. 3. Práticas. 4. Educação Superior. 5. Educação. I. Macedo, Yuri Miguel. II. Gave, Viviane Vaz. III. Oliveira, Artur Almenara Merlo Emmerich. IV. Almeida, Fabrício Silva de. V. Título 


\section{SUMÁRIO}

PREFÁCIO.

Sabrina Paradizzo Senna

TRANSCENDÊNCIA POSITIVA DA ALIENAÇÃO ATRAVÉS DA EDUCAÇÃO EM ISTVÁN MÉSZÁROS.......17 Viviane Vaz Gave

O 18 DE BRUMÁRIO E A CONTRIBUIÇÃO DE MARX PARA A COMPREENSÃO DOS FUNDAMENTOS DA DEMOCRACIA............................................................59 Artur Almenara Merlo Emmerich Oliveira

A RELIGIÃO COMO MELHORAMENTO DAS INTENÇÕES MORAIS EM IMMANUEL KANT...............117 Fabrício Silva de Almeida

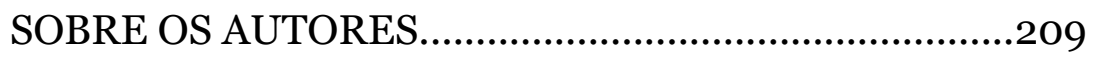





\section{PREFÁCIO}

A Filosofia tem sofrido fortes ataques, estão tentando de todos os meios torná-la inacessível tanto para o ensino médio quanto para o ensino superior. Acreditam que qualquer um é capaz de fazer o que os filósofos fazem em sala, no entanto, suas reflexões são rasas e fúteis, e por isso mesmo é que servem melhor ao governo.

Vivemos em um mundo atual onde o valor das pessoas é medido pelo que elas têm e o que fazem, vivemos um momento onde não há mais um referencial, cercados pela insegurança política e econômica. A Filosofia não deve ser vista como a salvadora de todos os problemas, até mesmo porque ela não traz respostas prontas e acabadas. Ela não tem como pretensão resolver todos os problemas da humanidade sozinha, nós filósofos temos - ou deveríamos ter - tal compreensão, mas o que devemos saber também é que ela é extremamente importante nessa mudança, pois ela investiga de forma racional os problemas nos quais vivemos, ilumina caminhos, ações e possibilidades, pensa o mundo real para modificá-lo.

A Filosofia é libertadora, é aquela que leva os homens a questionarem, que leva o ser humano a repensar seu modo de vida, a repensar toda estrutura já imposta e criada. A Filosofia é a saída do homem da caverna (pegando emprestado a definição platônica), é sair do pensamento pronto, dado e acabado, ditado, e chegar ao pensamento próprio, é o questionar do que é imposto. A Filosofia não dá respostas prontas e acabadas, mas ela abre possibilidades para pensar e questionar o que é vivido, é o abrir de mentes, o se lançar no mundo do questionar, o não ter medo de enfrentar a oposição, a busca de argumentos racionais e 


\section{$\varphi \quad$ Filosofia, Engajamento e Sociedade}

sólidos para chegar a uma conclusão. A Filosofia é o libertar das correntes, dos preconceitos, de ideias já dadas e préconcebidas. A Filosofia é essencial para a vida do homem e deve ser acessada por todos.

Aquele que se forma em Filosofia é bem diferente de qualquer outro curso, ele não é capacitado de forma prática ou técnica, mas ele é ensinado a usar a razão a todo tempo, como seu instrumento não só de trabalho, mas como modo de vida. No entanto, ele não deve se fechar para os outros conhecimentos, até porque a Filosofia é mãe de todos eles. A Filosofia, por ser bem diferente, tem características próprias de si. Quando falamos de ensino médio falamos de jovens, falamos do momento onde os seres humanos estão sendo moldados, onde se passa grande parte dentro de uma sala de aula tendo os professores como suas referências, e a presença do professor de Filosofia deve vir com uma posição de questionamento, que desperte a necessidade de conhecer, de perguntar, sendo de fundamental colaboração na formação dos desejos e personalidades dos alunos.

A Filosofia te prepara para mudanças, te ensina que o mundo está em constante transformação, apesar de estar sempre questionando ela prepara o homem para aceitar que as coisas são assim, pois não existe um único lado, uma única verdade acabada sobre todas as coisas, as visões são múltiplas, diferentes e todas devem ser respeitadas. Não significa, no entanto, aceitar qualquer visão aleatória sobre qualquer coisa, ou o simples questionar por questionar, mas a Filosofia é aquela que te ensina a ter base, a ter fundamentos, a argumentar com bases conceituais, a debater com sabedoria. Despertar o lado crítico do ser humano, mas críticas sólidas e argumentadas e não falas vazias. 
No entanto, é preciso ter cuidado com o modo como usamos essa racionalidade filosófica, ela não pode servir para nos afastar da compreensão humana da realidade, nos afastando das pessoas e tornando nossos discursos filosóficos banais com conceitos e palavras que nenhum outro fora do nosso círculo de estudos é capaz de compreender. Se temos como intenção usar a Filosofia para despertar as pessoas e tornar (ao menos capacitar essa possibilidade) o mundo melhor, devemos falar a linguagem que pode ser compreendida. A Filosofia não pode ser usada só como um meio de estudo e exegese de obras antigas, ela não deve se limitar a compreensão de autores, mas ela pode e deve ir muito além, ser usada na prática da nossa vida, ajudando a entender o modo de vida dos seres humanos, nossas relações, nossas capacidades, entender que ela está entrelaçada com vários âmbitos da vida humana, seja política, ética, religião, arte, etc. A Filosofia é extremamente útil a vida cotidiana dos seres humanos.

Nosso mundo é moldado para não agirmos como seres pensantes, ele nos empurra contra, nos esmaga, nos tira oportunidades, está repleto de tragédias e a cultura da violência e do individualismo tem cada vez mais se proliferado, o cansaço pelo modo de vida formado, o próprio modo de vida que o brasileiro leva, tudo é construído para que não tenhamos forças e vontade de pensar, para que as pessoas continuem perpetuando a ideia do não questionar e não criticar. Reparem no modo como educamos nossas crianças, cortando delas toda vontade de questionar, dando respostas banais ou imediatamente lhe dando algo eletrônico para se distrair.

$\mathrm{O}$ individualismo que a sociedade contemporânea vem pregando e desenvolvendo, a sociedade atual tem como base a meritocracia, o individualismo e os 


\section{$\varphi$ Filosofia, Engajamento e Sociedade}

estereótipos. Violência como característica na história da humanidade com tentativas de dominação, subjugação, aniquilação e extermínio por causa de padrões préestabelecidos que a Filosofia pode ajudar a quebrar rompendo a ideia de aceitação de uma verdade coletivamente imposta. Governos desacreditados, crenças abaladas, economia instável, relações líquidas, vivemos numa sociedade completamente perturbada e a Filosofia está sendo atacada no Brasil, e isso é um grande exemplo de como ela é importante, não querem retirá-la porque não tem valor, mas porque ela é tão valiosa que incomoda a quem não gosta de pensar.

Mas, mesmo com todo esse ataque do governo, tenho presenciado uma luta em favor da Filosofia. Antes ela era uma disciplina encarada pelos alunos, e até por outros professores, do ensino médio e de outras graduações do ensino superior como confusa e desnecessária, no entanto, esse cenário vem sofrendo transformação. Os professores começam a assumir os benefícios da disciplina nas escolas e os alunos cada vez mais interessados em conhecer essa matéria. A Filosofia tende a ser vista como aula vaga, ou a hora de viajar, a hora que podemos descansar e não fazer nada, porém, quando bem ensinada, a Filosofia é a aula mais cansativa, a aula que mais desperta a mente das pessoas, pois ela trabalha com temas, assuntos, questões que vão a fundo nos problemas do indivíduo.

A Filosofia destrói a ideologia enganosa que sofremos de todos os lados governamentais e das mídias manipuladoras, ela quer quebrar o senso comum, quer levar os seres humanos a serem críticos, a pensar e refletir sobre todas as informações que recebem. Nosso momento atual exige que os filósofos se levantem para voltar a ocupar nossos lugares de debates em todas as esferas, 
principalmente políticas e educacionais. O filósofo é movido pelo desejo de liberdade, pelo desejo de expressão e transformação, pela ânsia de buscar respostas para as mais variadas perguntas que o homem se faz ao longo de toda história - e que muitas ainda não possuem uma resposta. Costumo dizer nas minhas aulas que essa é a benção e a maldição da Filosofia: não há uma única resposta. Se quisermos saber o que a Filosofia pensa sobre liberdade já estamos fazendo a pergunta errada, o certo seria o que pensam os filósofos a respeito da liberdade, o certo seria perguntar o que eles têm a nos dizer e como ela pode nos levar a refletir nossa liberdade hoje. Para uma pergunta existem várias respostas que possibilitam os homens a refletirem sobre todas essas possibilidades, experimentando um pouco do pensar próprio, pessoal, de tirar suas próprias conclusões sobre uma determinada questão, e não somente acreditar no que nos foi imposto.

Quando falamos de pensamento pessoal, não queremos dizer um pensamento individualista, ou seja, não quer dizer que por existir conclusões próprias não se pense num coletivo. A Filosofia desperta as mentes para um pensar crítico próprio, mas com vistas a melhorar e acrescentar na vida prática social do homem como um todo. A verdadeira Filosofia é aquela que desperta no homem o questionar de questões do cotidiano e a tentativa de achar respostas para melhorar esse cotidiano social. Fala-se de discussões sobre liberdade, ética, moral, política, leis, religião, mas como dizia Hegel, se nada disso for aplicado ou ao menos discutido enquanto possibilidade de aplicação não serve para nada e não é a verdadeira Filosofia.

Aprendemos história com a justificativa de termos que voltar ao passado para não repetirmos os mesmos erros hoje, no entanto, sem a reflexão crítica que a Filosofia 


\section{$\varphi$ Filosofia, Engajamento e Sociedade}

propõe, cometeremos os mesmos erros por repetição, por condicionamento. A verdadeira Filosofia é aquela que questiona e critica sempre, é aquela que liberta. Ela chega na tentativa de formar cidadãos capacitados a conviver em sociedade, a pensar nos outros e a enfrentar as mais diversas situações.

O texto "TRANSCENDÊNCIA POSITIVA DA ALIENAÇÃO ATRAVÉS DA EDUCAÇÃO EM ISTVÁN MESZÁROS" escrito por Viviane Vaz Gave nos leva a refletir sobre o conceito de educação, de como realizamos o processo educacional na contemporaneidade. O trabalho nos leva a uma leitura educacional de viés marxista onde a educação é vista como instrumento emancipatório, no entanto, numa sociedade capitalista ela se torna instrumento de alienação. A alienação não deve ser vista como algo idealista, mas tem sua realidade na prática social, Marx vai até Hegel para extrair muitos de seus conceitos, no entanto, opta pelo materialismo histórico em oposição ao idealismo hegeliano. Na visão de Marx, o trabalho humaniza o homem, há a modificação da natureza para satisfação de suas necessidades básicas, o problema é quando o homem começa a ter necessidades secundárias que são criadas pelo próprio homem, o que acaba por gerar um estranhamento do trabalhador com seu trabalho. A autora usa Mészáros para explicar como essa autoalienação leva o homem ao consumo exacerbado, como o trabalho alienado deve ser superado e como a educação é a principal ferramenta de emancipação. O problema é quando a escola se torna lugar de reprodução da ideologia burguesa focada na transmissão de conhecimento de trabalho e se esquece de proporcionar uma formação humana crítica. Mészáros nos chama atenção para a ideia do "espírito comercial", onde acredita que o ímpeto de consumo não é naturalmente 
humano, mas é ensinado e reforçado por meio de instrumentos de dominação, como, por exemplo, as mídias. A obra "O 18 DE BRUMÁRIO E A CONTRIBUIÇÃO DE MARX PARA A COMPREENST̃O DOS FUNDAMENTOS DA DEMOCRACIA" escrita por Artur Almenara Merlo Emmerich Oliveira traz o tema da democracia na visão de Marx, com críticas e semelhanças a Feuerbach e Hegel, o autor mostra como Marx usa do materialismo históricodialético para compreender os fundamentos da democracia. O filósofo alemão inverte as ideias de um idealismo afirmando que a compreensão está na realidade, na matéria, e que a análise do homem, por exemplo, deveria ser feita dentro de um contexto histórico-social. O autor investiga ainda as ideias democráticas de um Estado Liberal no qual foram usados como base John Locke e de Jean-Jacques Rousseau, onde ambos acreditam num estado de natureza no qual os homens precisam consentir em um contrato social para garantir a autopreservação da comunidade. Pensam na democracia como sendo a escolha e decisão da maioria pelos rumos da sociedade sem levar em conta o conteúdo dessas decisões. O autor nos desperta para a ideia de uma democracia que se torna ideologia, onde a burguesia legisla para uma defesa das ideias e interesses burgueses e coloca a máscara do bem comum, fazendo parecer que quem é contrário ao Estado seria contrário à sociedade. A política deve fazer parte do próprio homem enquanto ser humano e não somente quando se torna cidadão de um Estado que vá garantir seus direitos. A ideia de soberania popular deve ser substituída pela ideia de autodeterminação e a de representação pela ideia de autogoverno, nos convidando a refletir sobre nossa 


\section{$\varphi \quad$ Filosofia, Engajamento e Sociedade}

compreensão de democracia, nossos ideais, nossa relação com a mídia e com o governo.
A produção,
“A
RELIGIÃO
COMO

MELHORAMENTO DAS INTENÇÕES MORAIS EM IMMANUEL KANT", redigida por Fabrício Silva de Almeida, visa mostrar o papel da religião dentro do quadro da filosofia moral kantiana. Para esse intento, o autor adota a leitura de que Kant entende a religião não apenas como uma união de pessoas com um credo comum, mas como devoção ao melhoramento moral. Aborda a concepção kantiana de fins da razão, pois é por meio da ideia de um fim racional da razão que Kant entende que a moral conduz inevitavelmente à religião. Diante disso, faz uma investigação das disposições morais em termos de condição de receptividade da lei moral, a partir do qual se impõe as noções de disposição para o bem e seu desvio para o mal. Dessa análise se extrai a evidência do mal moral na natureza humana, o imperativo de superá-lo e a possibilidade da conversão moral ao bem. Daí a necessidade de um progresso moral coletivo, pensado como um ideal a ser realizado não apenas individualmente, mas de modo cooperativo, o que Kant chamou de comunidade ética. Toda essa reflexão gerou a necessidade, por parte de Kant, de uma crítica à religião estatutária e a seu envoltório simbólico. Essa crítica mostra que os artigos mais fundamentais da fé eclesial devem ser relidos para saber se os seus conteúdos acenam para a melhoria moral do ser humano. Por isso, a hipótese principal deste texto é de que a função da religião racional é o aperfeiçoamento moral, que se constitui por meio de intenções moralmente boas. Isso levou Kant a colocar a religião nos limites da simples razão como o objetivo de, sob o tribunal da razão, atestar se sua simbologia pode ter significado moral. Com isso, a 
autor nos leva a pensar sobre a relação que existe entre o nosso comportamento e o papel da religião na melhoria da nossa condição moral.

As pesquisas apresentadas ressaltam a importância e a presença da Filosofia na nossa vida diária, abordando temas como a política, a religião, a economia, a educação, temas que estão tão presentes e parecem ser alheios a Filosofia, no entanto, essa publicação vem para mostrar exatamente o oposto, que a Filosofia lida sim com questões das paixões, da investigação da natureza humana, do papel do homem num contexto de sociedade, dos modos de governar e também com as questões religiosas, com a reflexão dos limites da religião dentro dos âmbitos da razão. A Filosofia se ocupa de questões centrais da vida humana como a relação que existe entre economia e educação, de como a educação acontece no mundo e como ela deveria ser, qual é o seu real papel dentro da sociedade. Ela não só lida e investiga, mas, nossos filósofos trazem várias possíveis respostas para esses assuntos em questão.

Sabrina Paradizzo Senna 
Q Filosofia, Engajamento e Sociedade 


\section{TRANSCENDÊNCIA POSITIVA DA ALIENAÇÃO ATRAVÉS DA EDUCAÇÃO EM ISTVÁN MÉSZÁROS'}

Inicialmente é explicado o conceito de alienação do filósofo alemão Karl Marx, para isso recorro às categorias marxianas que precisam ser esclarecidas, como: aufhebung, trabalho e estranhamento que são conceitos base para o desenvolvimento da teoria marxista. Trato também de uma suposta cisão, que é defendida por Louis Althusser, entre o "jovem Marx" e o "velho Marx". Essa não é uma distinção meramente cronológica, mas sim de método. Segundo Mészáros esta dicotomia é errônea.

O próprio Marx faz uma espécie de atualização do conceito de alienação durante suas obras. A importância de entender essa cisão é que de acordo com essa concepção, o jovem Marx é idealista. São nas obras do dito "jovem Marx" que o conceito de alienação que uso estão expressos, sendo importante para a hipótese deste trabalho que o conceito tenha seu sentido prático e material salvaguardado.

No segundo capítulo trato do conceito de educação como concebido por Marx para adiante elaborar a proposta de uma educação marxista. Tendo em mãos tal elaboração, parto para a crítica da educação da classe trabalhadora, explorando os diferentes aspectos da forma da educação e

1 Trabalho de conclusão de curso apresentado em 03 de dezembro de 2018, no curso de Licenciatura em Filosofia, da Universidade Federal do Espírito Santo sob a orientação do Prof. Dr. Maurício Abdalla e com avaliação da banca examinadora composta pelos professores Antônio Vidal Nunes e Sérgio Schweder. 


\section{$\varphi$ Filosofia, Engajamento e Sociedade}

o papel que ela desempenha no capitalismo. É neste capítulo que os conceitos de alienação e trabalho se relacionam, caracterizando o que Mészáros chama de "educação alienada".

A ideia absorvida a partir das obras de Mészáros, é apresentada no terceiro capítulo, sendo a educação o ponto inicial, de manutenção e a educação crítica, o ponto a ser alcançado e perpetuado, para enfim, a superação da alienação e da autoalienação do trabalho.

O que temos nas ideias de Mészáros é uma concepção de educação histórica e material, como deveria ser, partindo do pressuposto que o filósofo tem suas raízes nos estudos de Marx, não estando sectária em um campo de estudo, mas permeando todas as relações (econômicas, filosóficas, religiosas, culturais, etc) humanas, principalmente com a categoria de trabalho como descrita por Marx e explicitada no primeiro e segundo capítulo deste trabalho.

\section{ALIENAÇÃO EM KARL MARX}

Para o entendimento do conceito de alienação como se apresenta nas obras de Karl Marx, neste primeiro capítulo, centrei a minha pesquisa em seus estudos de juventude, e para tal, se fez necessário tomar algumas medidas para evitar equívocos metodológicos, tais como: a falsa dicotomia do "jovem Marx" e "velho Marx" feita por Louis Althusser e criticando esta "separação", a arguição de István Mészáros. Explicito o "conceito-chave" (MÉSZÁROS, 2016, p. 25) da filosofia marxiana de 
"Aufhebung"2. Mészáros dá atenção especial a esse termo porque "provê a ligação essencial com a totalidade da obra de Marx" (MÉSZÁROS, 2016, p. 25), também a categoria de trabalho e como ela é dividida (o trabalho que produz a humanidade e o trabalho alienado), e discuto uma das consequências do trabalho alienado: o estranhamento.

\section{O "jovem Marx" versus o "velho Marx"}

A minha opção de tratar os escritos da juventude dáse por dois fatores: o primeiro foi o tempo hábil para concluir esta pesquisa e por isso, para delinear o conceito de alienação e autoalienação marxiano, centrei-me na análise das seguintes obras: $A$ sagrada família ${ }^{3}$, Miséria da Filosofia4 e em especial nos Manuscritos econômicofilosóficos. E o segundo fator é que são nesses textos "da juventude" onde o tema da alienação é tratado com mais afinco.

A pergunta que Mészáros faz e a atribui como sendo a mais controvérsia é: "que lugar deve ser atribuído às obras iniciais de Marx em seu sistema como um todo?" (MÉSZÁROS, 2016, p. 197) e ainda separa em dois grupos opostos, filósofos que defendem uma ruptura de pensamento de Marx: o Marx que trata de "problemas da alienação" e um Marx tardio que busca fazer um socialismo científico. Dentre estes dois grupos pesam duas sentenças: o primeiro que idealizou o jovem Marx e contrapôs seus manuscritos iniciais às suas obras posteriores, já o outro

O próprio Marx, em seu posfácio da segunda edição alemã d'O capital (1873), assegura a importância e influência da dialética hegeliana em seu trabalho. Este ponto será discutido mais a frente.

3 Doravante $S F$.

4 Doravante $M F$. 


\section{$\varphi$ Filosofia, Engajamento e Sociedade}

grupo, simplesmente descartou as primeiras ideias como sendo idealistas.

Louis Althusser faz parte desse primeiro grupo e não entende todo o estudo e sistema de Marx como um único corpo teórico, mas o divide entre o "Marx filósofo" versus o "Marx economista". A crença da "ruptura epistemológica" nas obras marxianas foi herdado de Bachelard por Althusser, que a popularizou entre os teóricos marxistas por volta dos anos 1930. Segundo Althusser (2015) a cesura se dá em 1845, marco que antes ele denomina como período ideológico e pós 1845, o denomina período científico. Esse primeiro período é caracterizado principalmente pela atenção que Marx dá a problemática da alienação e termos especulativos tomados de Hegel e o segundo, Althusser descreve como a "maturação" teórica de Marx, que começa a se debruçar no campo científico para entender a realidade social.

Para exemplificar que Althusser subjuga os primeiros escritos de Marx, na introdução da edição francesa d'O capital, ele adverte:

Esta é a obra pela qual Marx deve ser julgado. Por ela apenas, não por suas "obras da juventude" ainda idealistas (1841-1844); não por obras ainda muito ambíguas, como A ideologia Alemã ou mesmo os Grundrisse [...]; nem pelo célebre Prefácio à contribuição à crítica da economia política (1859), em que Marx define em termos muito ambíguos (porque hegelianos) a "dialética" da "correspondência e da não correspondência" entre as forças produtivas e as relações de produção. (ALTHUSSER, 2017, p. 39, grifo do autor)

Seguindo em sua introdução, ele explica o status científico que a obra de Marx detém, principalmente para 
fundamentar o que ele julga ser a cisão no pensamento marxiano: "esta obra gigantesca que é $O$ capital contém simplesmente umas das três grandes descobertas científicas de toda história humana: a descoberta do sistema de conceitos (portanto, teoria científica) que abre ao conhecimento científico aquilo que podemos chamar de 'Continente-História' (Ibid, ibidem).

Jhon Macmurray (1935) aponta - ao mesmo tempo em que Althusser defende o oposto - que fazer essa oposição entre dois Marx e simplesmente descartar os escritos iniciais, dito "idealistas" é um erro e cometido em sua maioria pelos comunistas, pois segundo ele, a leitura é feita de modo a encontrar reflexos do estado que se encontram na teoria marxista. Apesar do alerta de Macmurray, Mészáros enfatiza que esta tendência de ruptura na filosofia marxiana não desapareceu, e pelo contrário, vem sendo "aceita por uma quantidade considerável de representantes da literatura filosófica corrente.” (MÉSZÁROS, 2016, p. 198)

Portanto, mostra-se equivocada a afirmação de um corte epistemológico entre os escritos da juventude e os posteriores. O trabalho de Marx deve ser entendido em trânsito, mas como um só corpo teórico; os escritos primeiros são fundamentais para entender e enquadrar as obras econômicas. Se aceitarmos a posição de uma cisão, cria-se o problema de delimitar onde termina e onde começa um período e outro de suas obras, bem como seria difícil apontar o quê exatamente sustenta essa cisão. Outro ponto é que não há contradição entre as obras e apenas classificá-las como "obras filosóficas" e "obras econômicas" é um erro crasso, visto que ao longo da produção de Marx, um tema permeia o outro. 


\section{$\varphi$ Filosofia, Engajamento e Sociedade}

\section{Sobre o conceito de alienação: idealista ou não?}

Uma pergunta que segue do debate "jovem Marx versus velho Marx", é se seu conceito de alienação é idealista. Em seus escritos, Marx critica não o conceito de alienação, mas sim a sua interpretação idealista. Mészáros afirma que "a esta altura deve estar claro que nenhum dos significados de alienação conforme usados por Marx nos Manuscritos 'caiu fora' dos seus escritos tardios." (MÉSZÁROS, 2016, p. 208).

Se assim fosse, seria admitir um corte epistemológico nos escritos de Marx. Mas vale elencar que a formulação inicial do conceito de alienação proposto por Marx é reformulado durante a sua trajetória, até porque, as considerações finais de Marx a partir de seus estudos não está explícito no primeiro momento.

Para Mészáros, o ponto em comum em todas as vertentes que "forçam" a cisão "jovem Marx versus velho Marx", é a intenção em contrapor a economia política da filosofia (e vice-versa). Parece que os autores que afirmam tal cisão procuravam mais uma polêmica no campo teórico marxista ou simplesmente não entendiam o todo de sua obra. Pode-se esperar um esgotamento de um termo após anos trabalhado e sua reformulação, mas nas obras de Marx não encontramos uma mudança radical no tema abordado, tampouco o abandono de uma área do conhecimento (a filosofia) para decidir por uma divisão de seus trabalhos.

Logo, devemos concluir levando em conta as assertivas de Mészáros, que o conceito de alienação não pode ser caracterizada como idealista, pois não só aparece ao longo de suas obras posteriores, como pode ser observado na história. Digo, o conceito de alienação como concebido por Marx é um fenômeno observável na 
sociedade, cumpre literalmente a práxis que lhe cabe, saindo da teoria e agindo no mundo.

\section{As categorias teóricas de Marx: “aufhebung”, trabalho e estranhamento.}

O termo Aufhebung é herdado da filosofia de Friedrich Hegel e pode ser considerado como pedra angular de toda a fenomenologia hegeliana, isso porque é ela que ilustra o movimento da realidade, o movimento do espírito absoluto, segundo Hegel (1998). Não há uma tradução em português que equivale em mesmo significado a esta palavra alemã, mas pode ser entendida como: aniquilar, conservar e elevar. Uma vez que objeto/ser/ideia se apresenta (tese), é confrontada (antítese) e é superada (síntese), aufhebung é o movimento, a realização da história.

Na Fenomenologia do Espírito, Hegel tenta formatar a realidade, postulando formas do Ser e de como perpassamos a realidade; Hegel (1998) mostra a caminhada que parte da consciência individual para uma consciência coletiva, e é através desse caminhar que podemos inferir que a consciência faz uma experiência da realidade. Assim pode ser sintetizada:

A história é concebida não como contingência, mas como necessidade do Ser que caminha rumo à plenitude de sua realização por meio da superação dialética (Aufhebung) da contradição entre sua finitude no mundo (sua existência determinada) e sua potencialidade infinita de Ser absoluto. A razão não está além ou separada da realidade; ao contrário "o racional é o real e o real é o racional". A historicidade do mundo é uma epopeia do Espírito, da qual o ser humano e suas realizações são apenas partes. (ABDALLA, 2009, p. 78). 


\section{$\varphi \quad$ Filosofia, Engajamento e Sociedade}

Ter em mente o termo aufhebung com todo o seu significado como explicitado acima, traçamos como tomamos consciência do mundo, o momento em que percebemos as coisas, o momento em que nossa consciência se percebe e como esta se comprova no mundo exterior (através da consciência coletiva), é então a consciência através desses passos que tem experiência da realidade.

Apesar da contradição intrínseca ao movimento dialético negar o posto e a sua negação, o resultado final do processo conservará de algum modo o que foi posto no primeiro momento em outro nível - dai surge o elevar como característica própria da dialética.

É no sentido de movimento de superação histórico que Marx adota a dialética helegiana. Apesar do fator principal ser diferente (idealismo de Hegel e materialismo de Marx), as duas concepções seguem com algumas semelhanças, como Markovic evidencia:

Toda historia es, pues, un proceso de autorrealización, y ello en un doble sentido: primero, porque había un potencial desde el principio un "ser o yo" potencial que debe materializarse o realizarse; segundo, porque no habrá necesidad de que ningún factor externo explique el movimiento: una y otra vez será puesto en marcha por las contradicciones internas que surgen de las condiciones limitadas de cada forma existente. (MARKOVIC, 1978, p. 67).

O que não sustenta as categorias de Hegel, é o seu caráter idealista, uma vez que o seu conceito de atividade e de mediação, são abstratas por se tratarem apenas de "entidades mentais", ao assumir tal posição, sua filosofia 
carrega as consequências através das descrições de suas categorias, "desde a identidade assumida de 'alienação' e 'objetivação' até a identidade última de 'sujeito' e 'objeto', bem como sua concepção de 'Aufhebung' enquanto 'reconciliação' meramente conceitual do sujeito consigo mesmo" (MÉSZÁROS, 2016, p. 85).

A teoria de Hegel é inviável para o materialismo marxiano, mas ainda sim resguarda pontos positivos. Tanto que Marx faz um "elogio" à Hegel pela sua conceitualização de trabalho. Hegel toma o trabalho como essência do homem que busca confirmação, mas enxerga apenas o lado positivo.

Marx diz: "o trabalho que Hegel unicamente conhece e reconhece é o abstratamente espiritual" (MARX, 2004, p. 124, grifo do autor), o que não basta para a correta leitura marxiana pois não se aplica ao trabalho prático, a "atividade produtiva" e sendo apenas abstrato, perde a sua capacidade de suprassunção, que visa a suplementação da alienação capitalista pelas vias práticas, que difere do "Aufhebung" da alienação proposta por Hegel, que se caracteriza como uma "negação abstrata, imaginária da alienação enquanto objetivação" (MÉSZÁROS, 2016, p. 88, grifo do autor).

$\mathrm{Na}$ formulação marxiana por sua vez,

a questão da "Aufhebung" deixa de ser um ato imaginário do "Sujeito" e se torna um assunto prático, concreto para o ser humano real. Essa concepção visualiza a suplantação da alienação por meio da abolição da "mediação alienada" [...], por meio da libertação do trabalho de sua sujeição reificada [...], para que seja humanamente ativo e chegue à satisfação das capacidades que lhe são inerentes na sua própria atividade produtiva, bem como na fruição humana dos produtos não 


\section{$\varphi \quad$ Filosofia, Engajamento e Sociedade}

alienados de sua atividade. (MÉSZÁROS, 2016, p. 89)

Esclarecimentos feitos, evidencia-se o caminho traçado por Marx ao incorporar parte da filosofia hegeliana à sua própria, principalmente $\mathrm{o}$ conceito de sumprassunção, que Marx passou a descrever a sua própria maneira, como movimento material da história, deixando o idealismo do termo em seu uso de origem.

Como a questão do trabalho é central para entender o conceito de alienação marxiano, e consequentemente entender a conduta adota por Mészáros, cabe aqui fazer uma breve distinção de tal conceito.

O trabalho (Arbeit) é entendido de duas formas por Marx: o trabalho que humaniza e nos diferencia da natureza e o trabalho que aliena e nos coloca na mesma categoria em que o objeto criado. Na primeira esfera, o trabalho é condição para que o homem se torne homem, ou seja, distinto da natureza (mas não indiferente a ela) pois a humanização se dá através da modificação da natureza, para atender as necessidades básicas do homem. É por meio do trabalho, da modificação da natureza que o homem constrói a sua humanidade e que se diferencia desta mesma natureza. Este processo ocorre em carácter histórico, através da sociabilização, é o trabalho que garante a continuidade do processo de humanização.

$\mathrm{O}$ estatuto da autoalienação do trabalho 5 dá-se não mais pela necessidade de suprir carências primárias

5São nos Manuscritos de 1844, junto a Engels, que ambos formularam o conceito de "autoalienação do trabalho", relacionando este fato a outros problemas filosóficos, como a função da religião, da arte, do direito; descrevem como superar definitivamente esta autoalienação e 
(comer, habitar) mas pela secundária criada pelo próprio homem (trabalho assalariado universal). O conceito de autoalienação do trabalho é crucial para o fim desejado da superação da alienação. Caio Antunes afirma que é o ponto de partida quanto o de chegada para suportar a concepção de educação em Mészáros:

Somente a partir de uma apreensão ampla do trabalho é que se pode compreender as razões pelas quais este configura tanto a causa, quanto o meio e o fim do processo histórico-social do ser humano causa da diferenciação entre ser humano e natureza, meio de constante humanização do ser social e fim, ou finalidade em si do próprio processo humano, uma vez que o ser social, em virtude do longo processo histórico já trilhado, não mais produz para assegurar sua condição animal, mas sim para, uma vez assegurada essa sobrevivência, desenvolver-se livre, isto é, humanamente. (ANTUNES, 2012, p. 25, grifo do autor)

O trabalho é então um meio para a formação humana, e que ao mesmo tempo, num sentido negativo do termo, é uma ferramenta para escravizar, afastar, estranhar desse estatuto de humano em vez de dar suporte para a nossa completa liberdade. Neste segundo tipo de entendimento do trabalho (o trabalho alienado) somos afastados do produto do nosso trabalho e passamos a sermos objetificados por eles, pois não mais nos reconhecemos no que produzimos. E esse aspecto não se dá somente no trabalho de manufatura e estagnado em fábricas, ora, as

não somente a sua suprassunção conceitual. (C.f. MARX, ENGELS, 2014) 


\section{$\varphi \quad$ Filosofia, Engajamento e Sociedade}

novas formas de trabalho e de exploração se apresentam de diferentes formas e sempre mudando. ${ }^{6}$

A relação entre o produto do trabalho e o trabalhador que se tornam estranhas (Enfremdemdung), ou seja, alienadas é assim explicada por Marx nos Manuscritos:

O produto do trabalho é o trabalho que se fixou num objeto, fez-se coisal, é a objetivação do trabalho. [...] Esta efetivação do trabalho aparece ao estado nacional-economico como desefetivação do trabalhador, a objetivação como perda do objeto e servidão ao objeto, a apropriação como estranhamento, como alienação. (MARX, 2004, p. 80 , grifo do autor)

Marx neste trecho exprime o fator imediato deste processo de alienação, de trabalho estranhado (Enfremdemdung), que é entendido quando o trabalhador que objetivou o produto não tem a posse sobre ele, logo, não tendo posse sobre o seu próprio trabalho e então, "a vida que ele [trabalhador] concedeu ao objeto se lhe defronta hostil e estranha" (Idem, ibidem).

Dentro desse estranhamento do trabalhador com o seu trabalho, desdobram-se ainda dois aspectos da alienação: o ser humano alienado do ser humano, em aspecto internalista, quando este não se reconhece dentro de um gênero, a sua espécie enquanto "homem". Tudo o que foi produzido pelo homem, o conhecimento, a cultura, as instituições e os produtos do trabalho, é história do Homem, deve-se entender do gênero humano, e portanto, de todos os viventes. Ora o que me garante como homem

\footnotetext{
6Trato aqui dos trabalhos em escritório, lojas, a categoria de setores terceirizados, professores entre outros. No subcapítulo a seguir, trarei mais aspectos dessa "alienação contemporânea" e suas novas formas.
} 
que faz história, é meu trabalho, esse trabalho me estranho pois não mais me reconheço, logo não possuo humanidade. O segundo aspecto é externalista, quando esse homem alienado passa também a relacionar-se com outro homem como objeto, como o produto do seu trabalho.

Entretanto, a estrutura e a forma do trabalho fora historicamente modificada, temos que tratar estes termos em sua atual concepção. Nesta nova forma específica de trabalho, onde temos a "subordinação formal do trabalho ao capital” (MÉSZÁROS, 2011b, p. 207), o capital ganha mais força para se tornar mais produtivo e lucrativo para si através dessa subordinação apontada por Mészáros, o que marca seu triunfo e expansão global devido a incorporação das mediações de primeira e - principalmente a - de segunda ordem.

Para uma "transcendência positiva" da alienação, Mészáros fala de um rompimento com as "mediações" que se caracterizam como i) propriedade privada, ii) troca, iii) divisão do trabalho (MÉSZÁROS, 2016, p. 78), que atravessam o caminho do ser humano e o produto de sua atividade (seja ela intelectual ou um bem material), que acaba por impedir seu exercício criativo, bem como a sua satisfação com o trabalho que produz. Noutra palavra: estranhamento.

Entretanto, Marx não fala de extinguir todos os tipos de mediações, apenas àquelas de forma alienada que é praticada pelo modo de produção capitalista. Assim, Mészáros usa os termos "mediação de primeira ordem" e "mediação de segunda ordem" para diferenciar as mediações que são fundamentais, ontológicas do ser humano com a natureza, e a segunda, sua forma alienada. (Mészáros, 2016, p. 78) 


\section{$\varphi \quad$ Filosofia, Engajamento e Sociedade}

No primeiro tipo de mediação, o homem produz para suprir suas necessidades de primeira ordem, por exemplo, saciar a fome e construir seu habitat. E a partir dessa primeira, se cria as necessidades sociais para produzir de um modo humano, por exemplo, comer com talheres e ornamentar as habitações.

Podemos entender essa relação como sendo direta entre o ser humano e a natureza, relação Sujeito-objeto, e não como se configura na segunda forma de mediação, onde o homem se vê estranho a si, assumindo a posição de objeto e acabando por se reificar, pois ele perde o valor inerente ao humano. Nesta segunda forma "a atividade produtiva constitui a fonte da consciência, e a 'consciência alienada' é o reflexo da atividade alienada ou da alienação da atividade, isto é, da autoalienção do trabalho". (MÉSZÁROS, 2016, p. 80).

Marx chama de "corpo inorgânico do homem" (MÉSZÁROS, 2016, p. 80, grifo do autor) tudo aquilo que ele produz que não está dado diretamente na natureza, como as obras de arte, artefatos e todo objeto modificado pelo trabalho, a este "corpo inorgânico do homem" (produto de sua atividade) não o pertencer, parece para ele estranho a si e pode então ser transformado em mercadoria (já que seu trabalho agora é um objeto externo e diferente), então tudo passa a ser enxergado como "coisa", é reificado, e até as relações fundamentais (mediações de primeira ordem) tem seu valor invertido.

Torna-se alienada a atividade que "desvia da função que lhe é própria, a saber, a de mediar humanamente a relação sujeito-objeto entre ser humano e natureza, e, em vez disso, tende a fazer com que o indivíduo isolado e reificado seja reabsorvido pela "natureza". (MÉSZÁROS, 2016, p. 81, grifo do autor) e ainda esta atividade não 
proporciona mais a satisfação, a realização do ser humano enquanto tal, pois as mediações de segunda ordem são institucionalizadas por vários meios (Estado, cultura e educação) e serve de barreira entre ser humano - ser humano e natureza - ser humano.

Ao envés de tomar o carácter emancipador a

inter-relação original do ser humano com a natureza é transformada na relação entre trabalho assalariado e capital e, no que concerne ao trabalhador individual, o propósito de sua atividade é necessariamente limitado à sua autorreprodução enquanto mero indivíduo em seu ser físico. Assim, os meios se convertem em fins últimos, ao passo que os fins humanos são convertidos em meros meios subordinados aos fins reificados desse sistema institucionalizado de mediação de segunda ordem. (MÉSZÁROS, 2016, p. 82) [Grifos meus].

Mészáros (2011b) entende que as mediações de segunda ordem do capital, configuram uma espécie de círculo vicioso, pois elas destroem o primeiro tipo de mediação e se colocam como o único interposto entre a atividade humana (e as condições vitais para a sua reprodução) e a natureza. Isso se dá pela preponderância do segundo tipo de mediação dentro do capitalismo atual, não conseguimos (e não seria viável) conceber a ideia de uma atividade produtiva humana separada da atividade produtiva industrial.

Portanto, a investida socialista com vistas a uma transformação verdadeira da ordem social deve ter como alvo o "próprio sistema do capital com todas as suas mediações de segunda ordem e não apenas a expropriação legal das personificações capitalistas privadas do capital." (Ibid, p.179, grifos do autor), porque por meios legislativos, 


\section{$\varphi \quad$ Filosofia, Engajamento e Sociedade}

a antiga ordem pode ser facilmente retomada pela própria via de ação que originou sua retirada. 7

Entende-se que a alienação sendo um dado histórico (MÉSZÁROS, 2016) e a história pode se descrever numa forma processual, podemos supor que ela é passível de mudanças e vem se constituindo assim desde a época dos escritos de Marx. Assim, o que temos hoje são novas formas de trabalho, novas classes e sub-classes, novas formas de controle (mídia, governo), mas algo é em comum em todos os velhos e novos aspectos desta transformação histórica: o processo educacional.

O trabalho alienado e sua aceitação pela classe trabalhadora é ensinado ${ }^{8}$, as mudanças históricas começam pela educação, portanto, mudando esse processo educacional (a sua forma institucionalizada, a ideologia que fundamenta as decisões dos formadores e os próprios atores políticos que dominam o processo educacional que encontram-se ainda alienados), muda-se a concepção geral do trabalho, que passa de mera obrigação sem sentido para um trabalho prazeroso e emancipador.

Neste ponto, Mészáros afirma que a autoalienação do trabalho é o principal alicerce de sustentação do sistema do capital (MÉSZÁROS, 2006, p. 76), uma vez que é o

7Pode servir de exemplo os vetos e leis que a então presidenta Dilma Rousseff sancionou durante seu mandato. A regulamentação do casamento entre pessoas homoafetivas fora formalizado pela resolução 175, em 14 de maio de 2013, a Lei do feminicídio, sancionada em 9 de março de 2015, sob $n^{0} 13.104 / 2015$, entre outras, que podem ser desmanteladas pelo atual presidente eleito, Jair Bolsonaro, que em suas propostas e falas, destrata os recém-conseguidos direitos das minorias. Este fato só comprova que dentro do Estado não há mudança que perdure, pois ela não é estrutural.

8Trato mais profundamente deste assunto no capítulo 2 deste trabalho. 
trabalhador explorado que reproduz as necessidades criadas pelo mercado, necessidades de segunda ordem como o consumismo exacerbado. $\mathrm{O}$ consumo em grande escala cria a necessidade de mais produtos e mais trabalhadores, gerando mais consumidores. São os próprios trabalhadores que consomem a maior parte do que eles mesmos produziram, porém de forma indireta, dando lucro ao empresário e dando continuidade a um círculo vicioso. Mészáros (2006) afirma que para alcançar a emancipação humana é necessário a superação deste estado de trabalho alienado.

Exposto isso, na literatura marxiana e marxista é possível encontrar a falha do sistema educacional e a resposta para essa falha. Marx criticando a forma em que a instituição escola nasceu e se desenvolveu, até uma concepção de uma educação comunista, e Mészáros com uma leitura refinada e atualizada da educação marxista como caminho para uma superação positiva da autoalienação do trabalho. O próximo capítulo aborda e discute a visão marxiana da educação.

\section{A EDUCAÇÃO MARXISTA}

A educação se torna aspecto principal do caminho para uma sociedade tal qual elaborada por Marx e pelos anarquistas e socialistas utópicos, porque seria o principal instrumento de transformação e emancipação do indivíduo. Esse objetivo só será alcançado quando o indivíduo em todas as instâncias - física e de consciência -, se vir livre das amarras opressoras. Isso se daria passando pela educação, pela ciência, pelo desenvolvimento da razão e a extensão desses e todos os conhecimentos.

As críticas, análises e opiniões descritas por Marx e Engels nunca se tratavam de diagnosticar - e tentar alguma 


\section{$\varphi$ Filosofia, Engajamento e Sociedade}

solução - concernente a conjectura presente às obras. Esses são apontamentos e estudos visando um futuro no qual a sociedade não é mais dividida em classes.

Ficou claro ao longo do estudo que o pensamento marxista faz críticas e supera o idealismo burguês presente no discurso filosófico da modernidade, tornando-se assim, parte do debate contemporâneo, que passa a formatar uma nova concepção de socialismo e de educação, delineando novas teorias educacionais, como a educação socialista que se apresenta num processo de transição da educação capitalista como é apresentada, para a educação verdadeiramente marxiana, ou seja, uma educação comunista.

Ao propor-se a discorrer do tema "marxismo e educação", todos os autores pesquisados para a elaboração deste trabalho de conclusão de curso, fizeram no início de seus respectivos textos um pequeno alerta que Karl Marx, em nenhum momento em sua vasta obra tratou própria e diretamente sobre a educação. Esta informação se torna útil para aguçar a leitura crítica de todo texto de educação marxista ou críticas a uma possível concepção da mesma.

Embora não tenha dedicado um volume único para tratar das questões educacionais, em vários de seus principais textos9, Marx aborda a educação de forma diluída, sempre acompanhando análises da história e como esta se relaciona com o trabalho e a educação. Muitos teóricos da filosofia, sociologia, pedagogia que utilizam como método teórico o materialismo histórico-dialético, debruçaram-se sobre os escritos marxianos para formalizar

9n'O Capital, Manifesto do Partido Comunista, Manuscritos econômicos-filosóficos, A ideologia Alemã, Criíica ao programa de Gotha, entre outros. 
uma análise marxista da educação. Por meio desses textos, pode-se afirmar que no pensamento de Marx, o trabalho tem um papel educativo, sobre esta afirmação, deixa de ser abstrusa ao longo do texto.

A questão da educação aparece no Manifesto do Partido Comunista, onde lê-se um revide à crítica da substituição da educação doméstica pela educação social:

[...]vossa educação não é também determinada pela sociedade? Pelas condições sociais em que educais vossos filhos, pela intervenção direta ou indireta da sociedade, por meio de vossas escolas, etc? Os comunistas não inventaram a intromissão da sociedade na educação; apenas procuram modificar o caráter arrancando a educação da influência da classe dominante. (MARX, 2005, p. 55).

Em outra passagem, de forma clara e seguindo tom de instrução, de forma mais elaborada, está descrito por Marx como deveria ser a correta aplicação de um ensino nos moldes socialistas, dando visibilidade à formação humana:

Por ensino entendemos três coisas:

Primeira: ensino intelectual;

Segunda: educação física, dada nas escolas e através de exercícios militares;

Terceira: adestramento tecnológico, que transmita os fundamentos científicos gerais de todos os processos de produção e que, ao mesmo tempo, introduza a criança e o adolescente no uso prático e na capacidade de manejar os instrumentos elementares de todos os ofícios. [...]

A união do trabalho produtivo remunerado, ensino intelectual, exercício físico e adestramento politécnico elevará a classe operária acima das classes superiores e médias. (MARX, apud, SAVIANI, 2012, p. 68) 


\section{$\varphi \quad$ Filosofia, Engajamento e Sociedade}

Em sua obra, $O$ Capital, Marx assinala novamente a junção do ensino básico com a politecnia, de acordo com ele, esse tipo de educação seria "o germe do ensino do futuro que unirá para todas as crianças além de uma certa idade o trabalho produtivo com o ensino e a ginástica, não apenas como método para aumentar a produção social, mas também como único método para produzir homens plenamente desenvolvidos" (MARX, apud. SAVIANI, 2012, p. 69).

\section{Sobre a instituição escola e seu desenvolvimento}

A educação em seus primórdios difere em estrutura e em grau da que nos é apresentada hoje. Foi nas sociedade tribais que vemos o nascimento da mesma, a educação era passada de geração para geração e não tinham lugar demarcado para tal. Praticada na hora de ir a caça, em rituais religiosos, tudo que envolve o conhecimento prático que poderia ser transferido para os outros integrantes, assim o era feito, a educação era dada por meio da relação e interação social. No desenvolver da história, a instituição que hoje denominamos escola sofreu mudanças estruturais, desde a necessidade do seu surgimento até a sua modernização.

A educação burguesa, como todos os aspectos estruturais da burguesia, foram extremamente necessários para o desenvolvimento da história. Por exemplo, a separação de Igreja e Estado cria uma vantagem para educação, para que ela possa ser abrangente também nas ciências, a criação e hegemonização de sistemas públicos de educação (uma vez que essa educação era privada aos monastérios e as classes altas).

Certas revoluções foram enfáticas, necessárias e duradouras, porém com elas, como a revolução industrial, 
criou-se um novo tipo de processo de produção e consequentemente de educação, esta que atende principalmente o sistema capitalista.

Com o avanço da tecnologia, a modernização das máquinas, exige-se também $\mathrm{o}$ aprimoramento e a capacitação dos trabalhadores para incorporar os novos saberes - que trata-se de saber operar um maquinário, ou apenas reparar e construir alguma parte dela - e para esses conhecimentos serem transmitidos de forma múltipla, contínua e eficaz, é necessário um novo meio de transmissão desses conhecimentos, com isso, temos o surgimento e ascensão da escola institucionalizada.

Apesar do aspecto de ampliação do alcance do sistema escolar, essa educação apenas instrui e amplia a força de instrução mas não a sua cognição, criticidade e criatividade. No entanto, não se deve desprezar os aspectos positivos: o analfabetismo que diminui, a cultura em si, que passa a desenvolver e aumenta a sua abrangência em todos os setores da sociedade. Mas com a universalização da escola não significa que, a partir desse momento, burgueses e trabalhadores começaram a receber a mesma educação. Pelo contrário, a escola reproduz a luta de classes. Quer dizer apenas que os trabalhadores tiveram que começar a frequentar um local específico e formal para terem uma formação que lhes permitisse trabalhar nas fábricas e ser disciplinados. Dessa forma, como não era mais possível restringir o acesso à educação escolar, negando o acesso ao conhecimento acumulado historicamente à classe trabalhadora, foi preciso dissimular essa educação a ponto de fingir que os saberes elaborados eram oferecidos a todos de forma igualitária. Entretanto, na prática, eram utilizadas várias estratégias para não ofertar aos trabalhadores uma educação que possibilitasse uma 
visão crítica da realidade e que desvelasse a sua condição de explorado. (PORTO, 2015, p. 457)

A educação da classe trabalhadora continua nos moldes a servir a produção capitalista. Basta uma simples análise em como é ofertada a educação para essa classe: a escola pública precarizada, o currículo escolar pobre em conteúdo, tendo somente o mínimo para uma formação técnica, leis que preconizam também as condições de trabalho do professor que assistirá esses alunos. tudo a fim de mascarar a real função que essa escola cumpre: a de fomentar a ideologia burguesa, internalizando seus valores, assim, a alienação chega a um nível de consciência, ou seja, é internalizada e reproduzida - inconscientemente ou não - pelo aluno. Como consequência, o aluno (e futuro trabalhador) deixa de ser (ou nem tem a possibilidade de ser) um sujeito crítico e atuante, para ser somente mais uma peça na maquinaria capitalista. Assim,

fica claro que há uma separação entre a formação burguesa, voltada para o ensino livresco e desinteressado, e a formação proletária, com ênfase na prática e na aprendizagem profissional. Essa separação é garantida por uma dualidade estrutural que determina o tipo de educação a que cada classe terá acesso. (PORTO, 2015, p. 458)

Discordo com a autora supracitada que contemporaneamente a educação, formação e ensino da "burguesia" seja "livresco e desinteressado". Apesar de concordar sobre a qualidade precária do ensino oferecido a camada mais pobre (geralmente filhos de trabalhadores) e que essa é voltada para a formação preparatória para o mercado de trabalho, o ensino oferecido aos mais ricos, ou a camada de classe média, também é voltada para 
aprendizagem de profissões. A grande diferença é que o filho do cidadão de classe média/alta estuda para ser médico, engenheiro, advogado, profissões que no imaginário popular dão status, profissões que tem o melhor salário. Ainda assim,

as desigualdades sociais e escolares acontecem de acordo com a divisão social do trabalho, e, portanto, as finalidades da escola para cada classe social vão ser diferentes e servirão, a princípio, para manter e reforçar o papel de cada uma no processo produtivo. (Idem, ibidem).

Entende-se a história como um processo dialético, a ascensão da escola está em seu ponto positivo, a sua negação, entretanto, é o subjugar do homem, a sua minimização. A proposta marxiana é então, superar (Aufhebung) essa fase negativa, a saber o capitalismo e suas formas institucionalizadas (escola, trabalho, família, etc). A sua superação se dá acentuando e desenvolvendo o potencial do capitalismo, explorar as suas possibilidades, para assim, emergir as suas contradições e os sujeitos críticos apontarem e agir para mudá-los e superá-los. $\mathrm{Na}$ pesquisa, a chave dessa mudança se dá pela retomada da escola, para esta voltar a seu ponto positivo, a saber, de criadora de novos sujeitos, que respeita a capacidade e não mais uma ferramenta para o capital.

A questão aqui não se trata de abandonar as instituições e avanços desenvolvidos pelo capitalismo, como o desenvolvimento da tecnologia, novas formas de comunicação, transporte e etc, Marx trata esse ponto da história como estágio transitório e antes de uma efetiva emancipação social, para de fato ser consolidada, deveria haver uma mudança na cultura, na educação, em nível de consciência. 


\section{$\varphi \quad$ Filosofia, Engajamento e Sociedade}

A preocupação de Marx era de "introduzir um novo tipo de ensino, unindo o trabalho manual ao intelectual, pretende estabelecer as bases de um sistema novo que terminará com a ideologização da ciência e as estruturas familiares e educativas estabelecidas. Marx ao pensar a educação, o faz tendo em vista o proletariado". (Textos..., 2006, p. 14)

Entende-se que a categoria trabalho na concepção de Marx não trata apenas da produção material; Marx propõe acabar com a distinção entre trabalho manual e o trabalho intelectual (MARX, 2012, p. 38). Excluir essa distinção, e ao contrário, juntar as duas formas de trabalho, é o único caminho para a superação positiva das duas formas de trabalho por uma nova forma, onde ao trabalhar o homem se desenvolve omnilateralmente, aumentando todas as suas capacidades máximas e então, "o trabalho tiver deixado de ser mero meio de vida e tiver se tornado a primeira necessidade vital" (MARX, 2012, p. 38).

Conhecimento é também meio de produção, portanto, é preciso lutar para a socialização deste tipo de conhecimento científico, e promover poder em todos os sentidos para a maior camada da população. Seria contraditório acreditar a esta altura que conhecimento técnico e científico ministrado na escola não seja também um produto para a elaboração do trabalho. A instrução dos alunos é vendida depois como sendo força de trabalho. Como já dito, a superação desta atual forma que coloca como diferente o trabalho manual versus trabalho intelectual, abre espaço para uma educação que forme o aluno humanamente, abarcando ambos aspectos que outrora buscava-se separar; assim o aluno sairá dotado do conhecimento científico (trabalho intelectual) e com o meio de produção (trabalho manual). 
Assim, para uma escolarização aos moldes marxista, diga-se com formação humana omnilateral, completa, que englobe as artes, a filosofia, o conhecimento técnicocientífico, uma escola que luta para a socialização desse conhecimento, é ferramenta imprescindível para a busca da derrocada do capital e de seu sistema que está emaranhado em todas as camadas da sociedade.

Essa nova educação não é requirida pelo sistema dominante, não é de interesse da classe política atual atender tais reformas e complementos no ensino público. Sobre o desinteresse interessado da classe dominante em não dar formação humana, Newton Duarte afirma:

[...] escola precisa ir além do cotidiano das pessoas e a forma de ela fazer isso é por meio da transmissão das formas mais desenvolvidas e ricas do conhecimento até aqui produzido pela humanidade. Não interessa porém, à classe dominante que esse conhecimento seja adquirido pelos filhos da classe trabalhadora. (DUARTE, 2012, p. 155).

A relação trabalho versus educação se descreve da seguinte forma: capital se apropria da força de trabalho $\rightarrow$ trabalho só interessa se produzir mais-valia, o trabalhador tem que estar apto, ter condições de gerar. Com estar apto, entende-se que ele sabe operar a máquina, trabalhar com a particularidades e esta qualificação é ensinada na escola. É um ensino direcionado para determinados saberes, fins que o mercado poderá usufruir, já que tem o trabalhador qualificado para o tipo de serviço que se demanda.

Além do ensino técnico, a escola reproduz também a nível ideológico o sistema dominante.

Antes de mais nada, é necessário assinalar que o aparato escolar levantado pelo modo capitalista se configura ideologicamente, não só em função dos 
componentes explicitamente - tematicamente ideológicos que comportamos também porque cria - e consolida um marco de cisão onde a alienação da força de trabalho é um fato natural. (Textos..., 2006, p. 15).

É válido frisar que é a estrutura da escola que acomoda seu carácter ideológico - servindo para qualquer ideologia - deve mudar então sua própria estrutura e não somente o carácter ideológico presente.

A divisão do trabalho é reflexo direto da implementação do modo de produção capitalista e Marx e Engels debruçam-se neste tópico e refletem sobre os efeitos dele. Com o trabalho sendo dividido, exige-se para cada parte, uma tipo de atividade específica e para suprir esta atividade, um conhecimento específico dela. Por exemplo, numa montadora de carros: precisa-se de vários profissionais especialistas em cada área do conhecimento responsável por um setor. Estuda engenharia mecânica para fabricar as peças; design para o "desenho" do carro, engenharia química para testes com o combustível, engenharia eletrônica para o funcionamento do software do carro, entre outras áreas num mesmo processo.

Essas subdivisões de trabalho e conhecimento, limitam a capacidade criadora do homem, limitando também seu conhecimento sobre a técnica geral do trabalho, exige assim, apenas uma parte da habilidade, mas não o suficiente para que o trabalhador permaneça em posse do mesmo, uma vez que este conhecimento, na forma do trabalho, é apropriado pelo capital.

Sob esse aspecto da divisão do trabalho, saliento as palavras de Engels:

Quais sentimentos e quais capacidades humanas pode conservar à altura dos trinta anos aquele que 
desde jovem trabalhou doze ou mais horas por dia, fabricando cabeças de pregos ou limando rodas dentadas e vivendo nas condições de um proletário inglês? A introdução do vapor e das máquinas não altera isso. A atividade do operário tornou-se menos pesada e o esforço muscular foi reduzido, mas o próprio trabalho, facilitado, foi levado ao extremo da monotonia. Ele não permite ao operário nenhuma possibilidade de atividade espiritual e, no entanto, absorve-lhe a atenção a ponto de impedi-lo de pensar em qualquer outra coisa. A condenação a semelhante trabalho, que toma do operário todo tempo disponível, que mal o deixa comer e dormir, que não lhe permite fazer exercícios físicos e desfrutar da natureza, sem falar da ausência de atividade intelectual - a condenação a um tal trabalho não rebaixa o homem à condição animal? (ENGELS, 2010, p. 158)

Se é o homem que garante a própria existência no ato do trabalho, a forma que este trabalho se apresenta e se desenvolve em determinado contexto histórico da sociedade interfere diretamente em como esse homem adquire a sua humanidade. A escola uma vez que é também inserida no mesmo contexto, também sofre interferências pelo modo de produção de determinada sociedade e consequentemente, é por ela que é proposto seu modelo de educação. E nesse ato de trabalho, acontece paralelamente $\mathrm{o}$ ato educativo, assim, a "origem da educação coincide, então, com a origem do homem mesmo" (SAVIANI, 2007, p. 154).

Quanto a educação e sua utilização,

Desde o princípio, viu-se que o ensino poderia converter-se em um dos meios fundamentais de dominação ideológica e, portanto, em um instrumento essencial para alcançar e consolidar a 


\section{$\varphi \quad$ Filosofia, Engajamento e Sociedade}

hegemonia da classe no poder. O estado de classe estava intimamente ligado ao ensino de classe. (Textos..., 2006, p. 17)

Se antes era a família, o grêmio, a igreja que era responsável por reproduzir ideologicamente os interesses da classe dominante, com o diluir dessas responsabilidades, ficou a cargo da escola tal função.

Se por um lado é positivo o ensino e educação ficar a cargo do Estado, pois em tese esse garante a universalidade e gratuidade da educação, por outro lado, quando a escola se torna um instrumento para reprodução da ideologia burguesa, Marx repudia veementemente a intervenção do Estado. Marx repele a intervenção do Estado na sociedade, essa relação se apresenta como estranha, uma vez que os interesses de ambas não se coincidem.

Quanto à discussão de disputar os espaços políticos: a escola também é lugar de disputar ideias e se configura como mais uma instituição do estado e tem que ser conquistada. Mas ainda sim, não existe a possibilidade de o processo de luta de todos os setores da sociedade juntos acabar num nível utópico de um "Estado bom”. Não se trata de negar as lutas desses setores por reformas e mantenedor da democracia e pluralidade, mas sim de sermos realistas que não exite a possibilidade de um "Estado bom”, esse não é o ápice que podemos alcançar.

No tocante à escola - entendida na sua forma institucional, Newton Duarte critica alguns teóricos marxistas por descartar as escolas como sedo ferramentas na luta contra o capital, porque trata-se de uma "esfera do Estado" (DUARTE, 2012, p. 156), eles diferenciam entre educação formal (o modelo padrão de escola institucionalizada) e a educação não-formal, que de acordo 
com os autores "estaria fora da influência do Estado e do capital" (Ibdem, ibid). Os apoiadores de cada modelo de escola tentam deslegitimar o seu diferencial, mas ambos os modelos são necessários para a formação humana e atuam cada qual com sua particularidade.

Numa leitura mais fiel à Marx, não temos que isolar e aprender somente o conhecimento produzido internamente (no caso, pela educação não-formal, que é fomentada por grupos de trabalhadores, como o MST, por exemplo), mas sim, apropriar-nos também de toda cultura, conhecimento e tecnologia produzida pelo capital. Isolar-se em uma "cultura do proletariado" é antidialético, porque retorna as práticas anteriores, que não deram certo (vide primeiros anos da União Soviética), não assumindo o salto positivo do desenvolvimento das formas de conhecimento, deixando de incorporá-los ao arcabouço do próprio estoque teórico e prático.

Compartilho desta visão de que tem que apropriar-se da escola institucionalizada tal qual ela se apresenta, mas os aspectos ideológicos devem ser retraídos e seu alcance universalizado, com a garantia de qualidade para todos. Newton Duarte assinala:

[...]a escola, em seu formato clássico, não é uma instituição essencialmente burguesa, que tem por principal função domesticar a classe trabalhadora. [...] O que precisamos fazer é superar os aspectos alienantes tanto da escola tradicional como de outras propostas de escola que surgiram na sociedade capitalista ao longo do século XX. [...] O que a classe trabalhadora precisa não é o fim da escola em sua forma clássica, mas sim sua universalização. (DUARTE, 2012, p. 164) 


\section{$\varphi \quad$ Filosofia, Engajamento e Sociedade}

Portanto, a escola deve ser encarada como um aspecto a ser debatido politicamente, mesmo que somente a reforma do Estado não seja suficiente para a total emancipação dos homens, mas é o início do caminho. Mészáros defende que "por mais desencorajadoras que sejam suas formas institucionais dominantes e suas práticas de autoperpetuação, não há opção fora da política" (2011b, p. 821) e que "a política é importante demais para ser deixada aos políticos" (Ibid, ibidem). O autor com essas afirmações, nos chama a atuação na sociedade, pois a mudança será sentida de dentro para fora; parte do indivíduo e suas ações, as ações aplicadas a todas as instituições (que por sua vez é formada por indivíduos). É usar da mesma fórmula da impregnação do capital, para destruir o próprio capital: da raiz.

\section{SUPERACָ̃̃̃ DA ALIENAÇÃO ATRAVÉS DA EDUCAÇÃ̃O}

"Nenhuma sociedade pode perdurar sem seu sistema próprio de educação" (Mészáros, 2016, p.265). Com essa afirmação, Mészáros entende que dentro da sociedade capitalista, as relações sociais não se sustentam e se reproduzem automaticamente, elas necessitam de uma reprodução ideológica. Apenas apontar teoricamente em qual setor desta sociedade o problema da perpetuação das relações consumistas parte é ineficaz, porém, é um início para uma análise crítica que se estende a todos os outros setores da sociedade.

Deve-se entender que a sociedade reificada funciona de tal forma somente por que os indivíduo internalizam as variantes exteriores, fazendo delas suas aspirações. $\mathrm{O}$ problema está que essas ideias geralmente são reproduções das relações sociais reificadas. Os desejos são produzidos 
para satisfazer um fetiche que também é criado em forma de várias narrativas que perpassam as nossas relações.

Mészáros $(2008,2016)$ aponta o sistema educacional como sendo o setor da sociedade responsável por transmitir e reproduzir tais ideias e que este tipo de reprodução, utilizando uma instituição que era pra ser livre e benéfica para a humaniza do homem, é o grande problema educacional. Cito:

a questão crucial, sob o domínio do capital, é assegurar que cada indivíduo adote como suas próprias as metas de reprodução objetivamente possíveis do sistema. Em outras palavras, no sentido verdadeiramente amplo do termo educação, trata-se de uma questão de “internalização" (MÉSZÁROS, 2008, p. 44, grifo do autor).

Quando Mészáros fala do processo de internalização das categorias e das relações capitalistas, pode-se entender que "educação" é algo em si do sujeito, está inerente a sua existência humana e em sociedade, e por se tratar deste indivíduo estar em sociedade, é preciso lembrar que "os homens fazem a sua própria história; contudo, não a fazem de livre e espontânea vontade, pois não são eles quem escolhem as circunstancias sob as quais ela é feita, mas estas lhe foram transmitidas assim como se encontram" (MARX, 2011b, p. 25).

Dado que "recebemos" a sociedade como está, acabamos por reproduzir as condições que nos precedem, sejam elas econômicas, sociais, culturais e educacionais. É esta herança que nos forma em nível de consciência; a sabedoria, a ciência, a técnica, a responsabilidade transmitida de geração para geração é a nossa humanidade. 


\section{$\varphi \quad$ Filosofia, Engajamento e Sociedade}

Todo este processo pode ser resumido numa palavra: educação.

Acontece que neste momento histórico, a educação que vem sendo guiada pelos interesses do capital - perde o foco da formação humana - aquela de transmitir saberes, história, produção e demais habilidades do gênero humano - para dar relevância apenas à internalização das "regras de convivência" sob o sistema capitalista, ou seja, para a "perpetuação da sociedade de mercadorias" (MÉSZÁROS, 2008, p. 80).

A educação formal é uma pequena parte do problema educacional, mas é a partir dela que ecoa e toma magnitude o verdadeiro problema. É a partir da educação formal que o homem aprende as bases sociais capitalisticamente modificadas e as internaliza, levando para a vida tais noções, de acordo com Mészáros, elas "adotam as perspectivas globais da sociedade como se fossem os limites inquestionáveis de suas próprias aspirações" (MÉSZÁROS, 2016, p. 266).

Portanto, a tarefa educacional transformadora que Mészáros propõe, ultrapassa a educação formal, mudando as forças politicas que regem essas instituições. Para uma transcendência positiva da alienação de segunda ordem, uma vez que o desenvolvimento do capitalismo se apresenta em todas as formas de relações sociais. Por todas as instituições estarem em sua forma reificada "a tarefa de transcender as relações sociais de produção capitalisticamente alienadas deve ser concebida no quadro de referência global de uma estratégia educacional socialista. Esta última, contudo, não deve ser confundida com alguma forma de utopismo educacional." (Idem, ibidem). 
A educação se encontra em crise. Dificilmente alguém negaria essa afirmação e para Mészáros (2016) a caminhada para chegar a um acordo sobre a gênese dessa crise, é longa. Mas "a persistência e a crescente intensidade da crise da educação nos principais países capitalistas" (MÉSZÁROS, 2016, p. 274) faz com que Mészáros a justifique numa sentença: "a crise atual não é simplesmente a de alguma instituição educacional, mas trata-se de uma crise estrutural de todo o sistema de 'interiorização' capitalista”. (Idem, ibidem).

Mészáros (2016) afirma que esta interiorização se apresenta na forma de falsa consciência, postulada pelas relações alienadas de produção de mercadorias, como se estas ideias fossem naturais, partindo dos indivíduos mesmos. Ora, nenhum ser humano nasce com o ímpeto de consumo, mas o é ensinado (mesmo que indiretamente, como propõe Mészáros, pela internalização). A relação estudo $\rightarrow$ trabalho $\rightarrow$ consumo, é estimulada e tida como normal. É deste tipo a relação que Mészáros descreve como sendo "espírito comercial” (MÉSZÁROS, 2016, p. 274).

Entretanto, em tempos de crise econômica, não é fácil a aceitação desses postulados, principalmente por não ser possível praticá-lo. Eis que o novo aparato "educador" do capitalismo - a mídia de massas - surge com propagandas que incitam implicitamente a "necessidade" de consumo de produtos supérfluos, fazendo parecer espontânea a vontade do consumidor. Essa é apenas uma das funções desse tipo de mídia, que se diz não ideológica e neutra. Com as novas tecnologias e aplicativos de comunicação, é muito mais fácil disseminar informações e manipular o indivíduo, fazendo que ele interiorize a mentalidade proposta pelos meios de comunicação e ache que surgiu de si, espontaneamente. 


\section{$\varphi \quad$ Filosofia, Engajamento e Sociedade}

A partir dessas constatações, entende-se por fim porque não fica a cargo somente da educação formal. Este é apenas mais uma das instituições que regem e formam as relações sociais e é preciso entender a sua crise [da educação formal] dentro desse conjunto mais amplo de relações. Nas palavras de Mészáros: "a educação formal está estreitamente integrada à totalidade dos processos sociais, e até mesmo no tocante à consciência do indivíduo particular, suas funções são julgadas de acordo com sua raison d'etre identificável na sociedade como um todo". (MÉSZÁROS, 2016, p. 277).

Portanto, a crise educacional formal é só o primeiro dos problemas, isso porque ele funciona em acordo com a estrutura maior que o permeia, o mesmo mecanismo que rege a interiorização da sociedade. A partir desta conclusão, Mészáros pondera:

essas instituições - incluindo as educacionais - são feitas para os homens ou os homens devem continuar a servir às relações sociais de produção alienadas? Assim, a "contestação" da educação, nesse sentido mais amplo, é o maior desafio lançado ao capitalismo em geral, porque afeta diretamente os próprios processos de "interiorização" por meio dos quais a alienação e a reificação puderam prevalecer até agora na consciência dos indivíduos. (idem, ibidem).

Na sociedade capitalista contemporânea, a educação formal cumpre dois papéis, de acordo com Mészáros (2016, pp. 277-278): “(1) produção das habilidades necessárias para gerir a economia" (Ibid, ibidem, grifo do autor), ou seja, capacitar os trabalhadores para cumprir tecnicamente suas funções (trabalho manual) e "(2) a formação dos quadros, bem como a elaboração dos métodos, do controle 
político" (Ibid, ibidem, grifo do autor), este segundo tipo se configura no que chamamos, no segundo capítulo deste estudo, de trabalho intelectual.

Mesmo concordando com a assertiva que as instituições educacionais não são todo o problema, concordamos que é uma parte essencial no processo de interiorização que perdurará por toda sua vida, então:

quer os indivíduos participem ou não - por mais ou menos tempo, mas sempre em um número de anos bastante limitado - das instituições formais de educação, eles devem ser induzidos a uma aceitação ativa (ou mais ou menos resignada) dos princípios reprodutivos orientadores dominantes na própria sociedade, adequados a sua posição na ordem social, e de acordo com as tarefas reprodutivas que lhes foram atribuídas (MÉSZÁROS, 2008, p. 44).

Entendemos que a base da força alienante não vem de todo da educação formal, e tampouco podemos esperar a solução para a alienação advinda somente desta instituição. Até porque, a escola que poderia ser mais uma ferramenta emancipadora, fora transformada numa instituição capitalisticamente alienante. Só levar em consideração que “o ‘capitalismo avançado' pôde seguramente ordenar seus negócios de modo a limitar o período de educação institucionalizada em uns poucos anos economicamente convenientes da vida dos indivíduos e mesmo fazê-lo de maneira discriminadora/elitista" (MÉSZÁROS, 2007, p. 294).

Para fins de não depositar - por utopia ou ingenuidade - toda a esperança de emancipação e da possibilidade de transcendência da autoalienação na educação formal, Mészáros alerta: 
Esperar da sociedade mercantilizada uma sanção ativa - ou mesmo mera tolerância - de um mandato que estimule as instituições de educação formal a abraçar plenamente a grande tarefa histórica do nosso tempo, ou seja, a tarefa de romper com a lógica do capital no interesse da sobrevivência humana, seria um milagre monumental. É por isso que, também no âmbito educacional, as soluções "não podem ser formais; elas devem ser essenciais". (Mészáros, 2008, p. 45).

A educação tem o papel central na construção e atualização de uma nova sociedade, e para reger esta corretamente, sob o teto do Direito, temos as leis. Observando que a prática política está constantemente associada à disputa de poder na sociedade (cf. BOBBIO, p. 954-62, 1989), nota-se que existem interesses de grandes empresas que dominam financeiramente e acabam por dominar também o Estado e a política, assim podendo favorecer ou não um ou outro setor específico da sociedade.

De acordo com Alysson Mascaro, "não é errado encontrar um vínculo próximo entre forma política e forma jurídica, porque, de fato, no processo histórico contemporâneo, o direito é talhado por normas estatais e o próprio Estado é forjado por institutos jurídicos." (MASCARO, p. 41, 2013). Tais grupos políticos que agem por interesse próprio e de grandes corporações podem facilmente - e frequentemente o fazem - manipular e abrir brechas, mas apesar da tendenciosidade, é essa mesma lei que nos serve e como participantes dessa comunidade temos de usufruir e o dever de cobrar.

O diagnóstico tomado sobre a institucionalização da educação é que "a educação [...] serviu - no seu todo - ao propósito de não só fornecer os conhecimentos e o pessoal 
necessários à máquina produtiva em expansão do sistema do capital, como também gerar e transmitir um quadro de valores que legitima os interesses dominantes" (MÉSZÁROS, p. 35, 2008).

De acordo com lógica capitalista é vantajoso instruir os trabalhadores, para que estes sejam menos ignorantes, saibam se comportar e devam ser disciplinados, e toda a estrutura escolar que nos é apresentada, principalmente em rede pública de ensino, segue essa ordem, do castigo severo, da extrema disciplina. Um diagnóstico de tal condição é que "sob a produção de mercadorias, o trabalhador deve ser reproduzido, assim como educado, somente - e no máximo - até os estreitos limites do 'tempo socialmente necessário' absolutamente imperante sob o capital." (ANTUNES, p. 79, 2012). Criam-se então cidadãos omissos e que apenas seguem ordens, não contestam nem questionam. Percebese que instrução do trabalhador é bem diferente de dar educação e formação humana.

A propósito, o modo como a educação é direcionada, tem respaldo nas leis, na instância do Estado; e lembrando as palavras de Marx: "o executivo no Estado moderno não é senão um comitê para gerir os negócios comuns de toda a classe burguesa" (MARX, ENGELS, 2005, p. 42). Respaldado na constituição e no Estado, fica claro que "uma das funções principais da educação formal nas nossas sociedades é produzir tanta conformidade ou 'consenso' quanto for capaz, a partir de dentro e por meio dos seus próprios limites institucionalizados e legalmente sancionados" (MÉSZÁROS, 2008, p. 45). 


\section{$\varphi$ Filosofia, Engajamento e Sociedade}

\section{CONCLUSÃO}

Com a derrocada do sistema do capital, há de se pensar noutra forma dialética de produção, distribuição e consumo. No capitalismo deparamo-nos com uma dialética enrijecida, pois aliena-se os meios de produção de quem produz, o que leva a criar um modo de controle dos trabalhadores a parte; esses que controlam e usurpam os meios de produção tem que criar predeterminações fetichizadas desse processo de produção. Todo esse processo deve ser então internalizadas de algum modo para causar a aceitação e o desejo de perpetuar o processo descrito.

O que fica cabido à educação: fazer com que os indivíduos queiram fazer e ser parte deste sistema, que "fetichizem" os fins e os produtos de seus próprios trabalhos alienados, sendo "subordinados ao impulso expansionista do sistema” (MÉSZÁROS, 2011b., p. 967). Acaba por haver um desiquilíbrio nas três esferas descritas: no processo de produção, de distribuição e de consumo. Essa distorção é proposital pois serve como pretexto para a manutenção da ideia falsa de liberdade de consumo, de variedade dos produtos e diversidade de oferta. Essas ideias falsas impulsionam o consumo, que por sua vez cria a necessidade de mais trabalho para pagá-lo (e manter o consumo) como forma de autolegitimação do sistema capitalista.

Partindo desse aspecto, o objetivo de transformação socialista não pode focar somente em descaracterizar as "personificações capitalistas privadas do capital, nem a tentativa auto contraditória de adaptar o "novo processo de vida social" aos constrangimentos estruturais deformadores dos "mercados de capital e trabalho". (Ibid, ibidem). O objetivo é a aniquilação dessa forma de dialética 
enrijecida do capital que detém um significado alienado de trabalho, para então alcançar o trabalho enquanto "necessidade primeira da vida”, como descrita por Marx:

Numa fase superior da sociedade comunista, quando tiver sido eliminada a subordinação escravizadora dos indivíduos à divisão do trabalho e, com ela, a oposição entre trabalho intelectual e manual; quando o trabalho tiver deixado de ser mero meio de vida e tiver se tornado a primeira necessidade vital; quando, juntamente com o desenvolvimento multifacetado dos indivíduos, suas forças produtivas também tiverem crescido e todas as fontes da riqueza coletiva jorrarem em abundância, apenas então o estreito horizonte jurídico burguês poderá ser plenamente superado e a sociedade poderá escrever em sua bandeira: "De cada um segundo suas capacidades, a cada um segundo suas necessidades!” (MARX, 2012, p. 38)

\section{REFERÊNCIAS}

ABDALLA, Maurício. Educar para a cooperação: A nova racionalidade e as perspectivas para a educação crítica. Vol. 1. 191 f. Tese (Doutorado Educação) - Universidade Federal do Espírito Santo, Vitória, 2009.

ALTHUSSER, Louis. Por Marx. Tradução de Maria Leonor F. R. Loureiro. São Paulo: Editora Unicamp, 2015.

. Advertência aos leitores do livro I d'O capital. In: “O capital”, Livro I. 2 ed. São Paulo: Boitempo, 2017. 


\section{$\varphi \quad$ Filosofia, Engajamento e Sociedade}

ANTUNES, Caio. A educação em Mészáros: trabalho, alienação e emancipação. São Paulo: Autores associados, 2012.

BOBBIO, Noberto. O futuro da democracia: uma defesa das regras dojogo. $4^{\text {a }}$ ed. Rio de Janeiro: Paz e Terra, 1989.

DUARTE, Newton. Luta de classes, educação e revolução. In: Pedagogia histórico-crítica e luta de classes na educação escolar. São Paulo: Autores Associados, p. 149166, 2012.

ENGELS, Friedrich. A situação da classe trabalhadora na Inglaterra. Tradução B. A. Schumann. São Paulo: Boitempo, 2010.

ENGELS, Friedrich, MARX, Karl. A sagrada família. Tradução de Marcelo Backes. São Paulo: Boitempo, 2009.

- Manifesto do partido comunista. Tradução de Álvaro Pina. São Paulo: Boitempo: 2005.

. Textos sobre educação e ensino. $5^{\mathrm{a}}$ ed. Tradução de Rubens Eduardo Frias. São Paulo: Centauro, 2006.

HEGEL, Georg Wilhelm Friedrich. Fenomenologia do Espírito. Parte I. Petrópolis: Vozes, 1998.

MACMURRAY, John. The early development of Karl Marx's thought. In: Lewis, John, Polanyi, Karl, Kitchin, Donald (orgs.). Cristianity and the Social Revolution. Londres, Victor Gollancz, 1935. 
MARKOVIC, Mihailo. El Marx Contemporaneo. Tradução de Célia H. Paschero. México: Fondo de Cultura Economica, 1978.

MARX, Karl. Crítica do programa de Ghota. Tradução de Rubens Enderle. São Paulo: Boitempo, 2012.

. Grundrisse. Tradução de Nélio Schneider. São Paulo: Boitempo, 2011a.

. Manuscritos Econômicos e Filosóficos de 1844. Tradução de Jesus Raniere. São Paulo: Boitempo, 2004.

- Miséria da Filosofia. Tradução de José Paulo Netto. São Paulo: Boitempo, 2017a.

. O 18 de brumário de Luís Bonaparte. Tradução de Nélio Schneider. São Paulo: Boitempo, 2011b.

$2017 \mathrm{~b}$.

. O capital, Livro I. 2 ed. São Paulo: Boitempo,

MARXHAUSEN, Thomas. História crítica das Obras completas de Marx e Engels (MEGA). Crítica Marxista, n. 39, p. 95-124, 2014. Disponível em: <https://www.ifch.unicamp.br/criticamarxista/arquivos_ biblioteca/artig02015_11_09_16_31_1133.pdf>. Acesso em 09/08/2017.

MASCARO, Alysson Leandro. Estado e forma política. São Paulo: Boitempo, 2013. 


\section{$\varphi \quad$ Filosofia, Engajamento e Sociedade}

MÉSZÁROS, István. A crise estrutural do Capital. 2.ed. São Paulo: Boitempo, 2011a.

- A educação para além do capital. Tradução de Isa Tavares. 2. Ed. São Paulo: Boitempo, 2008.

. A teoria da alienação em Marx. São Paulo: Boitempo, 2016.

- O desafio e o fardo do tempo histórico: o socialismo no século XXI. Tradução de Ana Aguiar Cotrim, Vera Aguiar Cotrim. São Paulo: Boitempo, 2007.

- Para além do capital: rumo a uma teoria da transição. Tradução de Paulo Cezar Castanheira, Sérgio Lessa. 1 ed. revista. São Paulo: Boitempo, 2011b.

PORTO, Camila Castello Branco De Almeida. A educação da classe trabalhadora: de Marx a Saviani. In: Revista Contemporânea de Educação, vol. 10, n. 20, julho/dezembro de 2015 .

SAVIANI, Dermeval. Trabalho e educação: fundamentos ontológicos e históricos. In: Revista Brasileira de Educação, Rio de Janeiro, v. 12, p. 152-165, 2007.

. Marxismo, educação e pedagogia. In: Pedagogia histórico-crítica e luta de classes na educação escolar. São Paulo: Autores Associados, p. 59-86, 2012.

TEXTOS sobre educação e ensino. In: Introdução. $5^{\mathrm{a}}$ ed. Tradução de Rubens Eduardo Frias. São Paulo: Centauro, 2006. 


\title{
O 18 DE BRUMÁRIO E A CONTRIBUIÇÃO DE MARX PARA A COMPREENSÃO DOS FUNDAMENTOS DA DEMOCRACIA'
}

\author{
Artur Almenara Merlo Emmerich Oliveira
}

Karl Marx desenvolve seu pensamento crítico quando a classe burguesa já começava a se estabilizar em grande parte dos países com capitalismo mais desenvolvido na Europa da metade do século XIX, especialmente França e Inglaterra. Neste diapasão, é mister observar que houve uma nova reutilização do termo democracia (cunhado pelos gregos) no novo sistema vigente. Para o filósofo alemão, o termo em análise não passa de uma Ideologia ${ }^{11}$, visto que se cria uma ilusão para que a sociedade acredite que é uma forma verdadeira, sincera e de emancipação, quando, na verdade, há relações obscuras por trás do véu que encobre a referida palavra.

Não se pode esquecer, todavia, que todo o pensamento de Marx deve ser compreendido com base em seu método de análise, qual seja, o materialismo históricodialético. Por isso, o primeiro tópico dessa tese abordará uma síntese do pensamento de Marx até o momento em que o autor cunhou seu método propriamente dito. De outra

10 Trabalho de conclusão de curso apresentado em o9 de julho de 2018, no curso Filosofia, da Universidade Federal do Espírito Santo, sob a orientação do Prof. Dr. Maurício Abdalla Guerrieri e com avaliação da banca examinadora composta pelos professores Dr. Antônio Vidal Nunes e Dr. Marcelo Martins Barreira.

11 Ideologia no conceito marxiano visto como falsa percepção da realidade. 


\section{$\varphi \quad$ Filosofia, Engajamento e Sociedade}

forma, será observado como Marx se utiliza de Feuerbach para criticar o idealismo hegeliano, mas, em seguida, retoma o pensamento de Hegel para criticar Feuerbach e, une as contribuições dos dois autores para criar o seu método próprio de analisar a realidade. Assim, deve-se fazer a negação da negação para se passar da aparência e se chegar à essência, o que na dialética hegeliana constitui o Aufhebung ${ }^{12}$.

No segundo tópico será estudado o pensamento dos autores liberais, quais sejam, John Locke e Jean-Jacques Rousseau, segundo os livros Segundo Tratado Sobre o Governo Civil e Do Contrato Social, respectivamente. No terceiro subtópico desta parte será feito um breve resumo dos pontos de comum acordo em que esses autores pensavam o Estado e a sociedade civil. Com isso, será possível compreender, ao menos em parte, o pensamento

\footnotetext{
${ }^{12}$ Este termo consiste na negação da negação - nega-se algo para se compreender o que não é aquilo, mas suprassumindo tudo o que lhe é essencial para, então, se chegar em um novo conceito dotado de mediações novas e anteriores essenciais. Assim, o termo que Marx se apropria em alemão - que inclusive é utilizado por Hegel - é o Aufhebung, que significa, ao mesmo tempo "levantar", "suprimir" (abolir) e "guardar" (conservar) (PERTILLE, 2011, p. 63). Esse termo fora usado por Hegel para explicação de sua dialética, nele observa-se: “a) consciência da própria Ideia, b) autonegação no sentido de uma limitação interna e c) ato de transcendência, isto é, de negação de ambas" (MARKOVIC, 1978, p. 83, tradução nossa). Em contrapartida, Marx verifica o termo de forma diferente, o que faz dele um "pensador revolucionário porque não há nenhuma forma histórica, do presente ou do futuro, que não mereça ser aufgehoben, isto é, a) ter abolido seu essencial limite interior, b) conservar suas características racionais e, c) ser elevada a uma etapa superior de desenvolvimento" (MARKOVIC, 1978, tradução nossa).
} 
liberal moderno, a fim de fazer um contraste para o estudo da contribuição do pensamento de Marx.

Em seguida, no item três, será estudado, no primeiro subtópico, o texto de Marx chamado $O 18$ de Brumário de Luís Bonaparte, que retrata a situação política na França, de 1848 a 1851, quando foi dado um golpe de Estado pelo membro da nobreza Luís Bonaparte, mas, para, surpreendentemente, se garantir os interesses da classe burguesa. Este livro em questão é relevante por se tratar de uma visão totalizante da época, além do viés históricopolítico que o mesmo possui. Será por meio deste livro em que se observará o pensamento liberal moderno sendo colocado em prática efetivamente, com todas as suas aparências, escondendo a essência dos atos, sendo que, o trabalho de Marx possui o intuito exatamente de desvendar este véu que esconde a realidade. É por isso que, no subtópico 3.2 serão verificadas as contradições da própria sociedade da época dos escritos do 18 de Brumário com o pensamento liberal burguês à luz do pensamento marxista. Ou seja, será observado como que a classe burguesa, que também sofreu com o golpe dado por Bonaparte, se saiu, em realidade, vitoriosa com todo esse horror de um regime autoritário - deixando claro que, faticamente, os autoritarismos não são desvios do sistema liberal, mas uma reorganização da própria democracia liberal burguesa. Já no último subtópico serão observadas, em síntese, algumas características sobre o que Marx teria pensado sobre a verdadeira democracia, à luz do pensamento do marxismo de Thamy Pogrebinschi, com o livro $O$ enigma do político: Marx contra a política moderna. Neste, serão observados os conceitos, principalmente, de autodeterminação e autogoverno, que se diferenciam dos conceitos liberais de soberania e representação, respectivamente. 


\section{$\varphi \quad$ Filosofia, Engajamento e Sociedade}

Por fim, serão feitas as considerações finais acerca do tema abordado nesta monografia, levando-se em conta que, mesmo que possa ser um assunto recorrente nos meios acadêmicos, é sempre importante lembrar do método do materialismo histórico-dialético marxiano para compreensão da realidade. Assim, perceber-se-á que a própria realidade do dia a dia não pode ser encarada com métodos simplistas ou simplificados de análise daquilo que é, mas que se deve procurar o máximo de correlações possíveis para uma mesma realidade. Só assim será possível que a aparência do ato seja superada e que se possa ver a essência daquilo que é. Em outras palavras, para se compreender a realidade, seja nos tempos modernos, seja no mundo contemporâneo, deve-se utilizar do método da dupla negação, do Aufhebung, e, tendo uma melhor compreensão da realidade, será possível entender melhor os modos de se agir a partir dela.

\section{O MÉTODO MARXIANO}

Em princípio, é necessário compreender a dialética hegeliana (que será revista por Marx posteriormente) para se entender como este filósofo enxergava as questões relacionadas à Sociedade Civil, família, Estado e Direito. Destarte, é importante dizer que

Hegel concebe a Ideia como sujeito da história, concebe a história como o movimento da alienação e do retorno do Espírito que se manifesta e constitui em-si e para-si como cultura humana, num processo dialético pelo qual as figuras da "Consciência" se constituem e manifestam como realidade, e a realidade, por sua vez, se constitui e manifesta como consciência-de-si humana, espírito e cultura humana (SILVA; EVANGELISTA, 2012, p. 4). 
De outra maneira, o Espírito Absoluto é o sujeito da história e a história é o processo de movimentação desse sujeito, que se coisificou no mundo ${ }^{13}$, em retorno à própria Razão/Ideia/Espírito. Por isso há uma manifestação do em-si e para-si, e é assim que se observa o caráter dialético de seu pensamento, porque o sujeito saiu de sua característica infinita e abstrata para tornar-se realidade e, após constituir-se como tal, há o processo da realidade retornar ao seu estado originário e infinito - a realidade se constitui como manifestação da própria consciência-de-si do homem para o retorno ao Espírito. Mas, vale dizer que só é possível essa consciência-de-si do homem por meio da história, é na história que se observa a tentativa de retorno da consciência-de-si para-si.

Dito isto, deve-se levar em consideração o pensamento de Hegel em relação ao Estado, Sociedade Civil e Direito. Para ele, o Estado seria o reflexo do Espírito Absoluto que, por meio do Direito, regularia e daria moldes à Sociedade Civil da época. Ou seja, se o Estado em questão fosse burguês, o Direito também o seria e, por conseguinte, a Sociedade Civil também, e assim se aplicaria nos processos históricos anteriores. Senão vejamos:

Hegel concebia o Estado como Espírito objetivo e como encarnação do Espírito nacional: seu critério era que o Estado só tem como fim o interesse geral que corresponde com sua categorização como Universo ético. Há uma transitividade direta entre o Estado e o cidadão: este obtém daquele proteção para seus interesses particulares e também, objetividade. O Estado é a garantia de que todos mantenham seus privilégios, contidos no Direito

\footnotetext{
13 As questões sobre o estranhamento, tanto em Hegel quanto em Marx não serão tratadas nesta monografia, visto que seria uma fuga muito grande ao tema do estudo.
} 


\section{$\varphi \quad$ Filosofia, Engajamento e Sociedade}

privado, e, assim mesmo, é concebido como centro unificador de significados sociais: como causalidade de uma nova forma de consciência social, que é definida pelo direito e configura a única forma possível de liberdade para seus membros (LABORDA, 1981, p. 189, tradução nossa). ${ }^{14}$

É importante salientar também que, para Hegel, a Sociedade Civil e o Estado são entidades que surgem, se manifestam e evoluem imediatamente um com o outro. Contudo, o Estado, ainda assim, é fundamento primeiro daquela.

Por meio da divisão da sociedade civil, a moralidade objetiva imediata evolui, portanto, até ao Estado que se manifesta como o seu verdadeiro fundamento. Esta evolução é a prova científica do conceito de Estado, e não há outra. Se o desenvolvimento do conceito científico chega ao Estado como a um resultado, quando ele a si mesmo se dá como o verdadeiro fundamento, é porque tal mediação e tal ilusão se anulam a si mesmas na imediaticidade. É por isso que, na realidade, o Estado é, em geral, o primeiro. No intrínseco dele, a família desenvolve-se em sociedade civil, e o que há

14 Hegel concebía el Estado como Espíritu objetivo y como encarnación del Espíritu nacíonal: su criterio es que el Estado sólo tiene como fin el interés general que se corresponde con su categorización como Universo ético. Hay una transitividad directa entre el Estado y el ciudadano: éste obtiene de aquél protección para sus intereses particulares y también, objetividad. El Estado es la garantía de que todos mantengan sus privilegios, recogidos en el Derecho privado, y, asimismo, es concebido como centro unificador de significados sociales: como causalidad de una nueva forma de conciencia social, que es definida por el derecho y configura la única forma posible de libertad para sus miembros (LABORDA, 1981, p. 189) 
nestes dois momentos é a própria idéia do Estado (HEGEL, 1997, p. 204).

Desse modo, o Estado é o fundamento por ser a encarnação do Espírito Absoluto no contexto da sociedade. Ou seja, tanto família como sociedade civil, enquanto se desenvolvem e evoluem já têm a moralidade objetiva do Estado/Espírito Absoluto como o fim. Assim, o fundamento delas é o Estado.

Por outro lado, Feuerbach, é um filósofo que criticou ativamente Hegel e do qual Marx se apropriou de algumas ideias (por exemplo tomar o homem como o sujeito real, o materialismo em si). Para aquele, o homem era o sujeito que compreendia o mundo, e não objeto do Espírito Absoluto, como propunha Hegel. E enquanto sujeito real, o homem era quem conseguiria entender as leis naturais através das análises dos objetos sensíveis e viver a vida igualitariamente com outros homens aplicando-se tais leis naturais em favor da humanidade (LABORDA, 1981, p. 197). Nesta esteira Feuerbach critica tanto a religião quanto a filosofia especulativa (principalmente a de Hegel) afirmando que as duas coincidem no mesmo erro -, pois estabelece que é impossível se pensar o infinito sem o finito - porque sem o finito, o infinito não existe e muito menos têm parâmetro - e que o pensamento feito por essas formas de pensar sempre caminhou do abstrato para o concreto, do ideal para o real, sendo que o necessário seria se estabelecer o caminho inverso (FEUERBACH, 2002, p. 24-25). Isto é, deve-se inverter o pensamento do idealismo para o materialismo, levando-se em consideração, então, que para se chegar ao conhecimento de algo, parte-se da matéria dada, do ser, do sensível e, destarte, o sujeito real (homem) consegue conhecer aquele objeto se utilizando de seu 


\section{$\varphi \quad$ Filosofia, Engajamento e Sociedade}

pensamento. Assim, pode-se dizer que "a verdadeira relação entre pensamento e ser é apenas esta: o ser é o sujeito, o pensamento o predicado. Pensamento provém do ser, mas não o ser do pensamento" (FEUERBACH, 2002, p. 31).

Em síntese,

Toda especulação sobre o direito, a vontade, a liberdade, a personalidade sem o homem, fora do ou acima do homem, é uma especulação sem unidade, sem necessidade, sem substância, sem fundamento, sem realidade. $O$ homem é a existência da personalidade, a existência do direito. Só o homem é o fundamento e o solo do eu de Fichte, o fundamento e o solo da mónada leibniziana, o fundamento e o solo do absoluto (FEUERBACH, 2002, p. 34).

Vale destacar que Marx critica o pensamento hegeliano partindo da crítica de Feuerbach, isto é, os dois possuem em comum tanto o sentido antropocentrista quanto o materialismo - vê o homem como sujeito e agente de ação e pensamento, aquele que pode alterar o ambiente à sua volta. Mesmo assim, ele afirma que a análise de Hegel não estaria de todo errada, mas que a (di)visão de Estado, Sociedade Civil e família foi feita de forma equivocada, isso porque o Estado nunca poderia ser o fundamento da Sociedade Civil nem da família, mas consequência. Ou seja, tanto a família quanto a Sociedade Civil que são pressupostos do Estado, tornam-se resultado daquele na filosofia especulativa, numa inversão equivocada,- o que Marx faz, então, partindo-se das ideias de Feuerbach é tomar a relação hegeliana e invertê-la para a posição que entendia correta (os fundamentos do Estado são a Sociedade Civil, família, homem) (MARX, 2010, p. 30). 
Contudo, após criticar a filosofia idealista/especulativa, Marx precisa acertar contas com o pensamento de Feuerbach e observa que este mesmo não é suficiente para a compreensão/apreensão do movimento real. Assim, Marx começa a explicitar alguns pontos de ruptura. Um deles seria a questão de que o homem teria que ser analisado em um contexto histórico-social:

Além de estruturar um caminho de libertação para o homem e o colocar como motivo fundamental do Direito, da sociedade e do Estado, opera com ele a partir de concretizações histórico-sociais: traduz o homem à sua desigualdade empírica no seio das relações sociais reguladas pelo Direito e sob o pressuposto de que ele é (ou deve ser) o sujeito de todos os processos em que se vê inserido (LABORDA, 1981, p. 198, tradução nossa).15

De outro modo, não há um homem natural, puro, uma essência do homem em si que seja universalmente aceita seria impossível se chegar ao "o que é o homem?" ou "sua essência" sem compreender a sociedade em que ele estava inserido e o contexto histórico-social em que estava.

Dessa forma, o que mais distancia Marx de Feuerbach em si é o caráter histórico, já que, enquanto para aquele as características histórico-sociais são fundamentais para a compreensão da verdade real, para esse a história só é importante quando for individualizada no contexto do ser

15 [...] además de estructurar un camino de liberación para el hombre y colocarlo como motivo fundamental del Derecho, la sociedade y el Estado, opera con él a partir de concreciones histórico-sociales: traduce el hombre a su desigualdad empírica en el seno de relaciones sociales reguladas por el Derecho y bajo el presupuesto de que él es (o debe ser) el sujeto de todos los procesos en los que se ve sumido (LABORDA, 1981, p. 198). 


\section{$\varphi \quad$ Filosofia, Engajamento e Sociedade}

humano, único, individualizado (LABORDA, 1981, p. 200201). Ou seja, Marx se utiliza da suprassunção ${ }^{16}$ para compreender o pensamento de Feuerbach e, em seguida, destrói aquilo que não condiz com o método que quer propor e, por fim, mantém aquilo que lhe é importante para compreensão da realidade - a visão a partir do homem. Com isso, ele consegue superá-lo e encontra em Hegel o necessário para solidificar seu método para compreensão e o estudo da realidade em que estava inserido. Ao perceber que o proposto por Feuerbach não é suficiente para compreensão da realidade, como dito anteriormente, Marx se apropria, com as devidas modificações, da dialética hegeliana e, assim, estrutura seu método necessário para o entendimento da sociedade de sua época.

Sendo assim, Marx verifica que no pensamento do próprio Hegel (mais especificamente em sua dialética) já existiam todos os pressupostos básicos para a sua crítica. Nas palavras do autor:

Critiquei o lado mistificador da dialética hegeliana há quase trinta anos, quando ela ainda estava na moda. Mas quando eu elaborava o primeiro volume de $O$ capital, os enfadonhos, presunçosos e medíocres epígonos que hoje pontificam na Alemanha culta acharam-se no direito de tratar Hegel como o bom Moses Mendelssohn tratava Espinosa na época de Lessing: como um "cachorro morto”. Por essa razão, declarei-me publicamente como discípulo daquele grande pensador e, no capítulo sobre a teoria do valor, cheguei até a coquetear aqui e ali com seus modos peculiares de expressão. A mistificação que a dialética sofre nas mãos de Hegel não impede em absoluto que ele tenha sido o primeiro a expor, de modo amplo e 
consciente, suas formas gerais de movimento. Nele, ela se encontra de cabeça para baixo. É preciso desvirá-la, a fim de descobrir o cerne racional dentro do invólucro místico (MARX, 2013, p.129, grifo nosso).

De outro modo, a dialética hegeliana, que parte da Razão, Ideia, ou Espírito Absoluto - o infinito - vem para o finito se desenvolver historicamente no homem com o intuito de retornar à consciência-de-si. Dessa forma, invertendo-se essa lógica, Marx observa que a dialética deve partir da realidade ${ }^{17}$, do material, do concreto, passar por operações racionais (determinações, que ocorrem no campo histórico-social) e, então, é possível verificar a verdadeira essência daquele objeto, matéria. Caso não haja a referida inversão, incorre-se no erro de verificar os fenômenos materiais apenas em sua aparência, mas não em sua essência, visto que não haveria parâmetro nem quanto ao início da abstração, muito menos quanto ao retorno porque o ser humano não poderia começar sua análise de algo abstrato, infinito, mas da materialidade em que se encontra.

Por fim, é importante dizer que, ainda na crítica a Feuerbach (e também a Bruno Bauer) ${ }^{18}$, Marx entende

\footnotetext{
17 Nesse caso, verifica-se que o objeto da investigação não pode ser o empírico, mas o real, porque a empiria seria um conceito que separa o conteúdo total da realidade, por isso, seria uma análise alienante. Ademais, para Marx, a realidade deve ser vista como prioridade do mundo dos seres particulares e individuais e dá ao pensamento a função de analisar a realidade pressuposta como objeto (LABORDA, 1981, p. 207).

18 Esses autores criticaram o idealismo hegeliano alegando que o mesmo desconsiderava o objeto para analisar a realidade, partindo-se sempre do abstrato. Para mais detalhes sobre a crítica a Bruno Bauer, ler A Ideologia Alemã.
} 


\section{$\varphi \quad$ Filosofia, Engajamento e Sociedade}

Ideologia como a falsa percepção da realidade. Isso porque, observou que eles, ao fazerem suas próprias análises da realidade, se utilizavam de conceitos já "consolidados" e "formados" pela sociedade de sua época, sem questioná-los em suas características histórico-sociais, tendo-os como conceitos materiais imutáveis. Em outros termos, a falsa percepção da realidade (ou Ideologia) ocorria porque esses pensadores não conseguiram inverter a lógica hegeliana nem aplicar as determinações histórico-sociais na materialidade concreta. Destarte, a essência para eles sempre ficou acobertada pela aparência.

Com essa breve síntese, é possível compreender o método do materialismo histórico-dialético de Marx e passar para o pensamento dos autores liberais, demonstrando-se, posteriormente, que o autor alemão se utiliza de seu método para criticar o conceito de democracia liberal, partindo-se dos acontecimentos (fatos históricos) observados no 18 de Brumário.

\section{OS AUTORES LIBERAIS}

Para se compreender a essência da democracia que pode ser extraída dos estudos e do pensamento de Marx, é de suma importância entender o que ela significa no pensamento de alguns liberais clássicos. Isso porque, é através do pensamento deles que será possível se utilizar do método marxiano do materialismo histórico-dialético e passar do pensamento ideológico para o essencial da democracia. Para tanto, antes de se adentrar no contexto do 18 de Brumário de Luís Bonaparte de Marx, e no estudo dos marxistas propriamente ditos, é mister analisar as ideias de John Locke e de Jean-Jacques Rousseau.

Todos os dois autores pensam a sociedade como proveniente de um estado de natureza (em que há plena 
liberdade dos indivíduos) que, com suas devidas proporções, são um momento anterior à comunidade política/civil. Além disso, eles defendem que os próprios indivíduos procuram consentir em um contrato social, em que todos se obrigam com a autopreservação da comunidade. É, também, interessante observar que, para os dois, o governo mais essencial da comunidade política, seria um governo em que a maioria pudesse decidir os rumos daquela comunidade, o que para eles é a democracia. A seguir será visto mais detalhadamente o que cada filósofo pode contribuir com o pensamento moderno:

\section{LOCKE E A DEMOCRACIA}

John Locke é um autor que busca legitimar o Estado soberano através de um Contrato Social feito pelos indivíduos. Isso porque, os seres humanos, para ele, encontram-se, em um primeiro momento, no estado de natureza, que é

[...] um estado em que eles [as pessoas] sejam absolutamente livres para decidir suas ações, dispor de seus bens e de suas pessoas como bem entenderem, dentro dos limites do direito natural, sem pedir a autorização de nenhum outro homem nem depender de sua vontade (LOCKE, 2001, p. 83).

Além disso, esse estado deve pressupor igualdade entre as pessoas que nele se encontram, visto que nascidos em uma mesma espécie e dispondo das mesmas capacidades não há motivos para desigualdades, nem para que um seja superior a outro, salvo se um ser que seja criador de todos delibere que assim o seja. Este estado, contudo, não é um estado em que tudo seja permitido, porque ainda nele o indivíduo estaria submetido ao direito 


\section{$\varphi$ Filosofia, Engajamento e Sociedade}

natural - conservar toda a obra do Criador e da criação, protegendo-a, ninguém deve, assim, "lesar o outro em sua vida, sua saúde, sua liberdade ou seus bens" (LOCKE, 2001, p. 84). A única questão importante que permitiria isso neste estado seria o direito à autoconservação, que sempre deve prevalecer, isto é, primeiro conservar-se e, depois, conservar toda a humanidade

A primeira situação que faz o homem querer sair do estado de natureza para uma comunidade civil acontece quando da aplicação de penalidades por infrações cometidas (qualquer natureza que seja ela). Esse caso se explica porque, neste estado, todos os seres humanos têm poder de aplicação da Lei Natural sobre os demais, seja para punir a ofensa causada seja para inibir os demais de causar aos outros a mesma ofensa. Todavia, a aplicação de uma lei se dá, muitas vezes, pelo uso da força, em que o transgressor pode ser mais forte que o ofendido, isto é, a lei torna-se ineficaz porque não haveria quem a aplicasse. Por isso, diz Locke:

Eu asseguro tranquilamente que o governo civil é a solução adequada para as inconveniências do estado de natureza, que devem certamente ser grandes quando os homens podem ser juízes em causa própria, pois é fácil imaginar que um homem tão injusto a ponto de lesar o irmão dificilmente será justo para condenar a si mesmo pela mesma ofensa (LOCKE, 2001, p. 88, grifo nosso).

Não se pode esquecer que a sociedade política é aquela em que os seres humanos, para proteger seus direitos e a propriedade privada, se juntam em comunidade, na qual entregam o poder de julgar e executar leis e normas para a própria comunidade, que fará esses atos. 
Aqueles que estão reunidos de modo a formar um único corpo, com um sistema jurídico e judiciário com autoridade para decidir controvérsias entre eles e punir os ofensores, estão em sociedade civil uns com os outros; mas aqueles que não têm em comum nenhum direito de recurso, ou seja, sobre a terra, estão ainda no estado de natureza, onde cada um serve a si mesmo de juiz e de executor, o que é, como mostrei antes, o perfeito estado de natureza (LOCKE, 2001, p. 133).

O membro da sociedade delega aos poderes legislativos e executivos os direitos/deveres de editar leis e fazê-las cumprir. Sendo que, seria possível, em determinados casos, até mesmo o próprio indivíduo fazêlas cumprir, quando ele puder executar determinada lei pessoalmente. Desse modo, se estabelecem leis para a comunidade pela própria sociedade, que as edita, e a execução das leis não se dá mais, em regra, de uma pessoa para com a outra, mas da força de todos os membros daquela comunidade em relação ao ofensor. Esse é um dos motivos segundo o qual a sociedade política se faz necessária - a execução das leis torna-se mais eficaz, porque se trata do interesse de toda a sociedade em relação ao indivíduo que infringiu a legislação.

Mas, no que diz respeito ao Contrato Social, em si, para Locke, só um acordo entre os homens faz com que eles possam sair do estado de natureza e ingressar na sociedade política. Em outras palavras, o Pacto não pode se dar por uma obrigação, mas por vontade das partes contratantes, que desejam se unir "para uma vida confortável, segura e pacífica uns com os outros, desfrutando com segurança de 


\section{$\varphi \quad$ Filosofia, Engajamento e Sociedade}

suas propriedades e melhor protegidos contra aqueles que não são daquela comunidade" (LOCKE, 2001, p. 139).

A comparação que Locke faz sobre o corpo político e o corpo humano são interessantes para compreensão tanto da sociedade quanto da democracia. Para ele, o corpo político, assim como o humano, age onde e quando houver maior aplicação de força (LOCKE, 2001, p. 139). Ou seja, se alguém deseja se locomover há um processo de maior aplicação das forças do corpo nas pernas desse indivíduo, que o movimentam para onde ele quer ir. Da mesma forma acontece com o corpo político, onde há maior exercício de força deve haver a decisão para onde pende essa força, sendo que ela é medida por uma decisão da maioria, já que a decisão se dá pela maior quantidade de vontades de membros sobre determinado assunto ou fato que deva ser discutido em assembleia. Em resumo, quanto maior a quantidade de membros que possuem vontade sobre determinada decisão, maior força aquela decisão têm e o corpo político deve agir conforme os parâmetros e anseios daquelas vontades que são maioria, visto que exercem maior força.

Pode-se perguntar aqui, então, o porquê que o restante da sociedade deve se submeter às vontades da maioria quando, em realidade, as decisões não poderiam ser da vontade daquela minoria de indivíduos que também compõem o corpo social. Ou seja, porque a vontade da maioria deve prevalecer em relação à da minoria. E a resposta de Locke leva em consideração que o pacto social, em regra, só foi formado, em primeiro lugar, porque houve vontade de todos em formar aquela sociedade/corpo político e, sendo assim, todos se obrigaram a se submeter à vontade da maioria, que é a vontade pública, independentemente. Assim, ou o pacto é formado em 
comum acordo e todos se obrigam ou o pacto não é formado e os seres não se obrigam (LOCKE, 2001, p. 140).

O filósofo, ao compor como deve ser o Estado, coloca como primeira lei fundamental da comunidade civil o estabelecimento do poder Legislativo, além, obviamente, da "preservação da sociedade e [...] de todas as pessoas que nela se encontram" (LOCKE, 2001, p. 162). Ele também admite outros poderes na sociedade, mas estes não tem o condão de alterar o legislativo. Apenas o legislativo, nomeado pela própria sociedade que fez e mantém o pacto, pode alterar o próprio legislativo. Em outras palavras, esse poder "é o poder supremo em toda comunidade civil, quer seja ele confiado a uma ou mais pessoas, quer seja permanente ou intermitente" (LOCKE, 2001, p. 163).

Contudo, isso não seria suficiente, visto que o poder supremo, nas mãos humanas, poderia decair por interesses privados. Assim, até mesmo esse poder deve possuir limites, dentre os quais, ele não pode ser contrário à vida da comunidade, nem tampouco dispor dos bens da mesma; ademais, encontra-se o fato de que o poder legislativo não pode governar senão em virtude da lei. Locke defende a legalidade, isto é, você não poderia ser punido por algo que não está na lei, ou algo que tenha sido criado apenas para punir determinada pessoa. Deve haver uma lei prévia para que as pessoas possam ter conhecimento se algo é legal ou ilegal perante aquela sociedade; ainda, "O poder supremo não pode tirar de nenhum homem qualquer parte de sua propriedade sem seu próprio consentimento" (LOCKE, 2001, p. 165); por fim,

Quarto: O poder legislativo não pode transferir para quaisquer outras mãos o poder de legislar; ele detém apenas um poder que o povo lhe delegou e 


\section{$\varphi \quad$ Filosofia, Engajamento e Sociedade}

não pode transmiti-lo para outros. [...] nem o povo pode ser obrigado a obedecer quaisquer leis, exceto aquelas promulgadas por aqueles a quem ele escolheu e autorizou para fazer as leis em seu nome (LOCKE, 2001, p. 168).

Cumpre recordar que, para Locke, quem faz o Pacto Social é o povo, os indivíduos de determinada comunidade que se juntam visando um bem comum entre eles - a preservação de suas vidas e propriedades. Desse modo, o poder supremo que o legislativo possui emana do povo, que é superior àquele e, consequentemente, se houver qualquer descumprimento tanto das leis fundamentais, quanto dos limites impostos, pode a sociedade retomar esse poder concedido e alterar o legislativo. Nas palavras do filósofo:

Deste modo, a comunidade permanece perpetuamente investida do poder supremo de se salvaguardar contra as tentativas e as intenções de quem quer que seja, mesmo aquelas de seus próprios legisladores, sempre que eles forem tão tolos ou tão perversos para preparar e desenvolver projetos contra as liberdades e as propriedades dos súditos. Nenhum homem, nenhuma sociedade humana, tem o poder de abandonar sua preservação, e consequentemente os meios de garanti-la, à vontade absoluta de um terceiro e a sua dominação arbitrária (LOCKE, 2001, p. 173);

\section{ROUSSEAU E A DEMOCRACIA}

Inicialmente, é válido dizer que Rousseau compreende como a primeira sociedade (e a única natural), ainda que não composta de um contrato entre as partes propriamente dito, a família. Essa instituição seria formada tacitamente, sendo que os pais seriam assemelhados aos 
governantes, enquanto os filhos aos súditos ${ }^{19}$. Além disso, existiria enquanto perdurasse a necessidade dos filhos em relação aos pais, pelo menos naturalmente. Em outras palavras, assim que os filhos não mais necessitassem dos cuidados dos pais, a eles não mais seria obrigatório o dever de obediência e se, mesmo assim, a família continuasse unida, seria por vontade das partes. Mas, para Rousseau,

A diferença toda está em que, na família, o amor do pai pelos filhos o paga pelos cuidados que lhes dispensa, enquanto no Estado o prazer de mandar substitui tal amor, que o chefe não dedica a seus povos (ROUSSEAU, 1999, p. 56).

O ser humano, para o filósofo, nasce livre e independente, encontrando-se no estado de natureza. Sendo assim, a instituição de um Estado é a vontade desses seres e o mesmo não tem necessidade de cuidar deles no mesmo sentido de que um pai deve cuidar de um filho, para que o mesmo sobreviva. As necessidades que o Estado deve satisfazer seriam de outra ordem, porque aquela relativa à chegada à fase madura já fora suprida pelos pais. Os pais, então, cuidam de seus filhos até os mesmos atingirem idade e discernimento para serem livres e independentes, enquanto, para o Estado, o cuidado deve ser para a manutenção dessa vida que já atingiu a liberdade e independência, que já não mais precisa dos cuidados paternos ${ }^{20}$. Por isso os pais cuidam com o amor e o Estado, ao se dedicar ao povo, o faz por outra ordem.

19 Expressão frequentemente utilizada por Rousseau para se referir aos cidadãos em uma sociedade civil.

20 Isso não quer dizer, obviamente, que na fase anterior ao amadurecimento o indivíduo não deva ser protegido pelo Estado, mas que, em regra, ele o é pelos seus pais. 


\section{$\varphi \quad$ Filosofia, Engajamento e Sociedade}

Insta salientar também que a primeira lei natural que deve ser respeitada e observada por todos, no estado de natureza (e até fora dele), é a lei da autoconservação do indivíduo (ROUSSEAU, 1999, p. 55). Com isso, o indivíduo deve se utilizar de todos os meios possíveis para sobreviver. Porém, a vida, em geral, possui inúmeras adversidades que ameaçam a sobrevivência do ser humano e que ele, sozinho, muitas vezes não consegue repelir, por isso a associação em sociedade civil é tão importante. Nos dizeres do filósofo, o homem no estado de natureza, para cumprir a primeira lei fundamental deve:

Encontrar uma forma de associação que defenda e proteja a pessoa e os bens de cada associado com toda a força comum e, pela qual cada um, unindose a todos, só obedece contudo a si mesmo, permanecendo assim tão livre quanto antes”. Esse, o problema fundamental cuja solução o contrato social oferece (ROUSSEAU, 1999, p. 69).

Em outras palavras, a sociedade civil, como organização, tem seu papel fundamental na preservação dos indivíduos e de suas propriedades privadas. Essa nova comunidade criada através de um Contrato Social pelos indivíduos livres e independentes forma um Estado soberano. Este Estado, por sua vez, terá uma lei fundamental, que é a lei que rege o Contrato Social e fundase no interesse comum de todos (com o intuito de preservação de suas vidas). Dessa forma, todas as decisões do Estado objetivam a sociedade e a sobrevivência dela ${ }^{21}$.

\footnotetext{
${ }^{21}$ Vale lembrar que Rousseau admite que toda sociedade, mais cedo ou mais tarde, irá sucumbir, mas o que ele deseja é mostrar meios para que a ruína da sociedade seja o mais lento possível.
} 
Nesta esteira, torna-se necessário dissertar sobre as formas de governos possíveis, e é aqui que entra a questão da democracia em Rousseau. A democracia ${ }^{22}$, para ser alcançada em sua plenitude, seria da seguinte forma, além de precisar de algumas condições:

Em primeiro lugar, um Estado muito pequeno, no qual seja fácil reunir o povo e onde cada cidadão possa sem esforço conhecer todos os demais; segundo, uma grande simplicidade de costumes que evite acumulação de questões e as discussões espinhosas; depois, bastante igualdade entre as classes e as fortunas, sem o que a igualdade não poderia subsistir por muito tempo nos direitos e na autoridade; por fim, pouco ou nada de luxo - pois o luxo ou é o efeito de riquezas ou as torna necessárias (ROUSSEAU, 1999, p. 150-151);

Contudo, Rousseau reconhece que a democracia perfeita é inalcançável pelos seres humanos, seria algo da esfera divina. Por fim, a democracia também é uma forma de governo sujeita a guerras e insatisfações frequentes, o que faz dela instável. Mas a instabilidade dela gera a liberdade da sociedade - porque, para o filósofo, seria melhor uma liberdade instável que uma escravidão estável (ROUSSEAU, 1999, p. 151).

${ }^{22}$ Em regra, são três as formas de governo. Além da democracia, as outras duas seriam a aristocracia e a monarquia, sendo possível, em cada caso concreto, haver combinação dessas formas. Enquanto a democracia seria um governo da maioria para o bem comum e o cumprimento do contrato social; a aristocracia seria um governo de poucos em favor da sociedade e do cumprimento do contrato; e a monarquia seria o governo de um (escolhido de forma hereditária ou pelo voto) em favor da sociedade e do cumprimento do contrato. 


\section{$\varphi \quad$ Filosofia, Engajamento e Sociedade}

Outra característica importante desta forma de governo da maioria que Rousseau ressalta é a relação dela para com o sufrágio (ou as eleições) para os cargos do Legislativo e Executivo. Essa característica é importante porque, para ele, a natureza da perfeita democracia deve levar em consideração o sorteio para os cargos eletivos e executivo. Isso porque:

Em toda verdadeira democracia, a magistratura não é uma vantagem mas uma carga onerosa, que não se pode justamente impor mais a um particular do que a outro. Somente a Lei pode impor essa carga àquele sobre o qual a sorte recairá, pois assim, tornando-se a condição igual para todos e não dependendo a escolha de nenhuma vontade humana, absolutamente não há aplicação particular que altere a universalidade da Lei (ROUSSEAU, 1999, p. 207).

E essa característica do sufrágio por sorteio corrobora com outra característica (que é mais fundamental em um regime democrático), qual seja, a igualdade. O sufrágio só pode ser por sorteio de tal modo que possa ocasionar igualdade entre os indivíduos da sociedade. Dito de outra forma, a sociedade, por meio do Pacto Social, forma o Estado, cujo objetivo é a preservação de todos os indivíduos e o cumprimento dos interesses da comunidade e, para tanto, é de suma importância que eles sejam colocados em pé de igualdade. O sorteio para os referidos cargos é, então, necessário porque dificulta as possibilidades dos seres humanos daquela sociedade escolherem determinado candidato por influências externas e pessoais e/ou para satisfazer seus próprios anseios pessoais e privados - o que seria contrário tanto à democracia quanto à própria proposta do Contrato Social. 
Por outro lado, Rousseau admite a escolha para as eleições em determinadas formas de governo, contudo, seria mais condizente com a aristocracia (ROUSSEAU, 1999, p. 208). Explicando: como essa é uma forma em que poucos decidem pela maioria, o certo seria escolher os poucos que tenham melhores possibilidades de escolher pelo interesse comum de todos.

O sufrágio como característica deve ser compreendido como possibilidade de representação. $\mathrm{Ou}$ seja, Rousseau entende que a verdadeira democracia deve ser aquela em que os indivíduos se fazem representar por si mesmos, sendo desnecessário o representante, principalmente no poder Legislativo, já que

No momento em que o povo se encontra legitimamente reunido em corpo soberano, cessa qualquer jurisdição do Governo, suspende-se o poder executivo e a pessoa do último cidadão é tão sagrada e inviolável quanto a do primeiro magistrado, por onde se encontra o representado não mais existe o representante (ROUSSEAU, 1999, p. 183, grifo nosso).

Todavia, como essa democracia é impossível de ser observada na realidade, o filósofo também disserta sobre as possibilidades de representação. Em primeiro lugar, diz que toda lei aprovada por representantes e não ratificada diretamente pelo povo é nula, em absoluto (ROUSSEAU, 1999, p. 187). Em segundo lugar,

Não sendo a Lei mais do que a declaração da vontade geral, claro é que, no poder legislativo, o povo não possa ser representado, mas tal coisa pode e deve acontecer no poder executivo, que não passa da força aplicada à Lei (ROUSSEAU, 1999, p. 188). 


\section{$\varphi \quad$ Filosofia, Engajamento e Sociedade}

E, por fim, ao verificar as sociedades históricas, ele propõe que essa democracia plena só foi possível em sociedades que se utilizavam de regimes como a escravidão e a servidão, o que dava aos membros da sociedade (porque escravos e servos não eram vistos como cidadãos perante tais regimes) a possibilidade de se ocuparem com o interesse comum, já que havia quem se preocupasse com o trabalho.

Então, Rousseau (que não é favorável à escravidão), diz que está apenas constatando que a liberdade da modernidade, ao mesmo tempo que traz liberdade, a retira, porque é livre de um em relação a outros mas não o é quando se tratar de um representante - a sociedade entrega sua liberdade àquele que a represente. Em outras palavras, "no momento em que um povo se dá representantes, não é mais livre; não mais existe" (ROUSSEAU, 1999, p. 188).

Por último, para compreender a democracia, em Rousseau, ainda é válido destacar a questão de pequenas associações ${ }^{23}$ na sociedade (que seria a grande associação). Quando há partidos/associações, diminui as opiniões e divergências e, assim, a opinião geral torna-se deficitária, porque as pessoas não emitem suas opiniões por si mesmas, mas por meio dessas associações, que não necessariamente esboçariam o que todos os seus membros pensam. Nesta esteira, menor o número de associações, pior seria o quadro, visto que seria mais difícil extrair a verdadeira vontade geral da sociedade. Por isso, na democracia, Rousseau propõe que todos possam dar suas próprias opiniões, sem que haja comunicação de um para com o outro, para que se possa extrair a livre vontade do cidadão

23 Facções ou, em uma visão mais contemporânea, partidos políticos. 
e, assim, chegar a uma vontade geral da sociedade. Em suas palavras:

Importa, pois, para alcançar o verdadeiro enunciado da vontade geral, que não haja no Estado sociedade parcial e que cada cidadão só opine de acordo consigo mesmo (ROUSSEAU, 1999, p. 92).

\section{O ESTADO NO PENSAMENTO LIBERAL}

Conforme exposto, algumas considerações devem ser feitas a fim de se entender os pontos em comum dos autores liberais e o que forma uma possível coesão de seus pensamentos e verificar uma certa diferenciação com o método de Marx. Obviamente que, consoante explicitado, os liberais entre si, possuem diferenças em suas análises, mas estas não serão tratadas neste ponto especificamente.

Portanto, observa-se que os pensadores do iluminismo tomaram em conta a formação do Estado moderno ${ }^{24}$ por meio de um Contrato Social. Este é feito por pessoas pré-concebidas em um estado de natureza, também pré-imaginado. A grande questão aqui é a diferenciação deste pensamento com o método do materialismo histórico-dialético de Marx. Inicialmente porque, apesar de Rousseau, e até Locke, analisarem de uma certa forma questões históricas, eles não as utilizam para compreender o mundo que os envolve. Isto é, as questões históricas para eles servem simplesmente para corroborar seus pensamentos e não para refletir a realidade dos acontecimentos - eles não passam da aparência.

24 Não se pode esquecer, neste ponto, que a formação do Estado moderno para esses autores e para o próprio liberalismo tem, na democracia, como a sua perfeição, o seu primor. Ou seja, esse Estado será tratado neste subtópico como o Estado moderno em sua característica democrática. 


\section{$\varphi \quad$ Filosofia, Engajamento e Sociedade}

O estado de natureza pensado pelos autores levam em consideração seres humanos que não necessariamente existiram e, mesmo que o tenham, já estão imbuídos de valores pré-constituídos pela própria sociedade em que os pensadores se encontram e que tem como forte tendência de crescimento o pensamento liberal burguês. Destarte, as mediações histórico-sociais que compuseram e compõem a sociedade são deixadas de lado em suas análises, porque os seres humanos já foram feitos na história, com seus valores já pré-determinados, não cabendo a eles se autodeterminar.

De outro modo, porém, o Estado moderno, a partir do Contrato Social, é formado pela união de vontade dos indivíduos livres e independentes, o que leva a crer que, diferentemente do que Hegel passou a pensar, os liberais iluministas pensavam a sociedade como constituída de indivíduos para o Estado. Ou seja, o Estado seria o reflexo desses indivíduos, a união de suas vontades, e não o contrário. Verifica-se que, apesar de todas as diferenças, seria possível dizer que esse modo de pensar - levando-se em consideração que os indivíduos que fazem a sociedade e, então o Estado, e não o contrário - tem uma certa semelhança com o pensamento marxiano.

Outra diferença que cabe ser contemplada é o fato de que os autores liberais, em nenhum momento tentam chegar na real essência dos acontecimentos. As lutas sociais que ocorrem no próprio Estado não são abarcadas pelo pensamento deles, porque elas colocam em consideração apenas um pensamento certo e outro errado, sem levar em conta todas as mediações histórico-sociais de todos os pensamentos. Dito de outro modo, eles exaltam suas democracias, como governo da maioria, sendo que o que a maioria pensa é o pensamento correto que deve ser a vontade estatal - para eles, e aos olhos do Estado, a maioria 
sempre estará certa, sendo que, aquele que votou minoritariamente deve saber-se errado após a votação. Nas palavras de Rousseau:

O cidadão consente todas as leis, mesmo as aprovadas contra sua vontade e até aquelas que o punem quando ousa violar uma delas. A vontade constante de todos os membros do Estado é a vontade geral: por ela é que são cidadãos e livres. Quando se propõe uma lei na assembleia do povo, o que se lhes pergunta não é precisamente se aprovam ou rejeitam a proposta, mas se estão ou não de acordo com a vontade geral que é a deles; cada um, dando o seu sufrágio, dá com isso a sua opinião, e do cálculo dos votos se conclui a declaração da vontade geral. Quando, pois, domina a opinião contrária à minha, tal coisa não prova senão que eu me enganara e que aquilo que julgava ser a vontade geral, não o era. Se minha opinião particular tivesse predominado, eu teria feito uma coisa diferente daquele que quisera; então é que eu não seria livre (ROUSSEAU, 1999, p. 205).

Ocorre que, em nenhum momento os autores liberais levam em consideração o conteúdo do que é decidido em assembleia, ou pela vontade da maioria. O que eles fazem é verificar se aquela vontade representa a vontade geral - o "bem de todos" - ou não. Sendo assim, deixa-se de lado os motivos e atos que geram a vontade geral ou o porquê de uma determinada decisão em relação a outra(s).

Ademais, o poder Legislativo, no pensamento liberal, é aquele que possui as maiores benesses, garantias e poder propriamente dito, porque ele é o poder que mostra à sociedade a vontade de todos (ou da maioria). É um poder supremo porque apenas por ele é possível se verificar qual a real vontade dos indivíduos que compõem a sociedade, enquanto os demais poderes tem o condão apenas de julgar 


\section{$\varphi$ Filosofia, Engajamento e Sociedade}

ou colocar em prática tais vontades ditadas pelo Legislativo. Neste momento não cabe analisar os benefícios e garantias do poder Legislativo ou o porquê dele ser o poder supremo, mas de se observar como os liberais davam grande importância a esse poder, principalmente para se constituir uma democracia real.

Cumpre dizer, também, que os liberais, por meio do Contrato, pensam em um Estado como ente despersonalizado, isolado da sociedade e dos conflitos sociais que são parte integrante dela. Ele se molda em um bem comum de todos, que seria a força motora sobre a qual a sociedade é formada - é por meio do bem geral da nação que há a união das pessoas em um Estado e há a formação do Estado para a proteção de todas as pessoas, pelo menos é o que pensa esse pensamento liberal. E aqui está um panorama da diferença que será vista adiante em relação ao pensamento marxiano - este filósofo alemão entende que há interesses divergentes e contraditórios entre as diversas classes (que se dividem, principalmente, por conta de um viés econômico), o que reflete sobremaneiramente na própria política. Isto é, os conflitos sociais que existem na própria sociedade civil, que se divide em classes, são refletidos no ambiente político.

Dito isto, resta a análise de Marx (se utilizando de seu método do materialismo histórico-dialético) sobre um Estado moderno liberal, cujos moldes seriam semelhantes àqueles pensados pelos pensadores liberais já demonstrados - qual seja, o Estado francês de 1848 a 1852 - o que será feito no tópico que se segue. 


\section{A CRÍTICA MARXIANA E A ESSÊNCIA DA DEMOCRACIA}

\section{MARX E O 18 DE BRUMÁRIO}

O 18 de Brumário de Luís Bonaparte retrata, na visão de Marx, o modo pelo qual Luís Bonaparte, sobrinho de Napoleão, dá um golpe de Estado na França e contra a própria burguesia, com apoio de parte dela e, principalmente, da grande massa populacional (que era o campesinato) e, mesmo assim, manteve e propagou os ideais burgueses na esfera político-econômica. Em outras palavras, um golpe de Estado que era pra ter sido contrário à burguesia, ao final e contraditoriamente, favoreceu os interesses burgueses.

É válido um pequeno resumo para compreensão do caso - isso porque, nestes escritos, Marx fala algumas características que podem ser tomadas de um regime democrático observado na França burguesa daquela época. Assim, a análise torna-se importante para, sobre isso, retirar aquilo que seria essencial à democracia e aquilo que seria apenas aparência de determinado momento histórico - não-democracia travestida de democracia.

Inicialmente, cabe a constatação de que as revoluções burguesas tiveram um viés revolucionário, mas logo que chegaram ao seu apogeu tentaram liquidar todo ímpeto e tempestade revolucionária da sociedade. Já as tentativas de revoluções proletárias, por outro lado, ao invés de se unir, se segregavam e criticavam constantemente a si próprias (MARX, 2011, p. 29-30). Dito de outra forma, enquanto as revoluções burguesas do século XVIII buscaram um bem comum para sua própria classe, as proletárias se divergiam em interesses fragmentários da classe proletária. Além 


\section{$\varphi \quad$ Filosofia, Engajamento e Sociedade}

disso, quando as revoluções burguesas triunfaram em seus interesses, colocaram as demais tentativas revolucionárias proletárias ou de outros setores, como ofensa ao bem da sociedade e, por isso, deveriam ser perseguidas.

O primeiro momento é chamado de Prólogo por Marx. Neste momento, em 1848, com a queda de Louis-Philippe, foi instituído um governo provisório:

Todos os elementos que haviam sido preparados e definidos pela revolução, a saber, a oposição dinástica, a burguesia republicana, a pequena burguesia democrático-republicana e o operariado social-democrata encontraram provisoriamente $\mathrm{O}$ seu lugar no governo de Fevereiro (MARX, 2011, p. 32 , grifos do autor).

Porém, cada um dos segmentos deste governo provisório deu a sua roupagem ao que seria compreendido como República, isto é, a res publica (coisa pública) era diferente para cada uma das classes e segmentos da sociedade, que compreendiam como bem comum de todos, interesse geral, e seus sinônimos, de forma diversa, sendo que uns abarcavam maior parte da sociedade, outros pequena parcela, alguns possuíam interesses revolucionários e outros conservadores, uns pensavam em uma emancipação da comunidade já outros na emancipação privada e de poucos. E enquanto o proletariado encontrava-se às ruas, com as armas nas mãos proclamando a República Social, os demais segmentos da sociedade se uniram para se fortalecer politicamente, principalmente com o apoio das massas camponesas e pequeno-burguesas.

Enquanto o proletariado parisiense ainda se comprazia na contemplação da ampla perspectiva que se lhe descortinara e se entregava a discussões 
bem-intencionadas sobre os problemas sociais, os velhos poderes da sociedade se reagruparam, reuniram-se, ponderaram e receberam o apoio inesperado na massa da nação, dos camponeses e pequeno-burgueses, os quais se lançaram todos de uma só vez à arena política após a queda das barreiras da Monarquia de Julho (MARX, 2011, p. 33).

O segundo período é marcado pela Constituição e a fundação da república burguesa. Houve uma Assembleia Nacional que se reuniu com o sufrágio da Nação e a representava. Todavia, os setores do proletariado observaram que tal Assembleia reduziria a revolução aos níveis meramente burgueses e, por isso, tentaram dissolvêla. Mas não lograram êxito e seus principais líderes foram presos, executados e/ou exilados. Em seguida, o proletariado de Paris tentou responder a declaração da Assembleia Nacional Constituinte com o que ficou conhecido como insurreição de Junho - mas nesta, os proletários foram massacrados e a burguesia saiu triunfante (foi a primeira grande guerra civil na história de proletariado contra a burguesia) (MARX, 2011, p. 34-35). Para Marx, o grande problema é que a burguesia tinha o apoio de praticamente toda a sociedade ${ }^{25}$, enquanto o proletariado não tinha apoio algum, a não ser deles mesmos.

Depois desse acontecimento, houve uma espécie de caça aos socialistas, comunistas e simpatizantes reprimiam-se movimentos sociais, divulgavam-se ódio a

25 Teve apoio "da aristocracia financeira, da burguesia industrial, da classe média, dos pequeno-burgueses, do exército, do lumpemproletariado [...], das capacidades intelectuais, dos padrecos e da população do campo" (MARX, 2011, p. 34-35). 


\section{$\varphi \quad$ Filosofia, Engajamento e Sociedade}

essas pessoas e aqueles que pensavam de forma semelhante, incentivavam-se um nacionalismo exacerbado. Vale dizer que tudo isso com amplo apoio dos meios de comunicação ${ }^{26}$ que, muitas vezes, eram financiados tanto pela burguesia como pela pequena burguesia - como escritores, advogados, etc. Ocorre que, a perseguição que, em princípio, é apenas aos ditos socialistas e comunistas, começa se ampliar, porque todos os demais movimentos sociais vão sendo taxados como também socialistas e comunistas e, assim, percebe-se que um tiro foi dado no próprio pé - tudo em nome da "Propriedade, família, religião, ordem" (MARX, 2011, p. 36).

Ainda na segunda fase, houve a eleição de Bonaparte em 10 de dezembro de 1848, o que colocou fim à Constituinte, e com a nova Carta Maior, houve a deliberação do Estado-Maior das liberdades. Mister salientar, porém, que essa nova Constituição ressalvava grande parte dos direitos em nome do direito dos outros e da segurança pública, deixando a regulamentação da própria Constituição à cargo da Assembleia Nacional que fora eleita. Contudo, essa Assembleia, composta majoritariamente pelo Partido da Ordem (principalmente grande burguesia) e, também, por bonapartistas, estabeleceram as regulamentações constitucionais consoante os interesses burgueses. Nos dizeres do filósofo

[...] a Constituição constantemente remete a leis orgânicas futuras que devem detalhar aquelas notas marginais e regular o gozo dessas liberdades irrestritas de tal maneira que não entrem em choque umas com as outras nem com a segurança

\footnotetext{
${ }^{26}$ Neste estudo não caberá análises profundas da relação dos meios de comunicação e a democracia ou sobre a democratização dos próprios meios de comunicação para a democracia.
} 
pública. Mais tarde, essas leis orgânicas foram implementadas pelos amigos da ordem e todas aquelas liberdades foram regulamentadas de tal modo que a burguesia, ao gozar delas, não ficasse chocada ao ver as demais classes gozarem dos mesmos direitos. Quando ela proibiu "aos outros" essas liberdades ou lhes permitiu gozá-las sob condições que implicavam outras tantas armadilhas policiais, isso sempre ocorreu apenas no interesse da "segurança pública", isto é, da segurança da burguesia, como prescreve a Constituição. Em consequência, ambos os lados se reportam, posteriormente e com toda razão, à Constituição tanto os amigos da ordem que suprimiram todas aquelas liberdades quanto os democratas que exigiram o seu cumprimento. Isso se deve ao fato de que cada parágrafo da Constituição contém a sua própria antítese, a sua câmara superior e a sua câmara inferior, a saber, na sentença universal, a liberdade e, na nota marginal, a revogação da liberdade. Portanto, enquanto a denominação da liberdade foi respeitada e somente a execução efetiva desta foi impedida [...] a existência constitucional da liberdade permaneceu incólume, intocada, por mais que a sua existência ordinária tenha sido suprimida (MARX, 2011, p. 42-43).

Finda a Constituinte, inicia-se o terceiro período analisado por Marx em relação ao Golpe de Estado ocasionado por Luís Bonaparte, que se subdivide em três pequenos momentos. O primeiro é a luta entre a socialdemocracia e o Partido da Ordem com a aliança de Bonaparte. Em seguida, verifica-se, com a vitória sobre a social-democracia, uma espécie de ditadura parlamentar pelo Partido da Ordem. Por fim, o terceiro período é marcado pela disputa entre o Partido da Ordem contra 


\section{$\varphi \quad$ Filosofia, Engajamento e Sociedade}

Bonaparte - o que culmina no referido golpe em 02 de dezembro de 1851.

Em uma breve síntese, após a Constituinte, os partidos com maior número de parlamentares eleitos foram o Partido da Ordem (com maioria parlamentar) e o partido da social-democracia (com quantidade considerável de parlamentares). Ocorre que, como o Partido da Ordem era maioria e a social-democracia era um partido conciliador, os parlamentares mais radicais deste último partido foram perdendo seus líderes por perseguição política em nome do interesse público e segurança pública. Com isso, houve vaga de vários cargos parlamentares, que foram ocupados, principalmente, pelos setores conservadores da sociedade - dessa forma, a social-democracia é derrotada em seus interesses, prevalecendo a maioria da burguesia no Parlamento.

Com essa maioria, o Partido da Ordem passa a perseguir ainda mais as demais classes e aprovar leis favoráveis aos interesses da burguesia, sem observação das massas da sociedade. Por isso, se estabelece uma espécie de ditadura Parlamentar, visto que, como a burguesia tinha maioria e isso era o necessário para aprovação das leis e regulamentos, ela legislava conforme seus interesses e os colocava como interesse geral. O grande desgaste, nesta fase, ocorreu quando a burguesia resolveu alterar a lei eleitoral, aprovando uma legislação mais rigorosa em que diminuía em grande parte o número de eleitores e, principalmente, do eleitorado proletário - novamente, um tiro no pé, visto que mais tarde, isso foi usado por Bonaparte como anseio das massas e ele apoiou o retorno da legislação anterior. A nova lei abolia o sufrágio universal, colocava como requisito domicílio fixo de três anos no local da votação para os eleitores e "a comprovação desse 
domicílio ficava sujeito, no caso dos trabalhadores, a um atestado a ser emitido por seus empregadores" (MARX, 2011, p. 84-85, grifo nosso).

Essa e outras medidas acabam por desgastar o Partido da Ordem frente aos interesses da própria burguesia, quanto aos interesses das demais camadas da sociedade. Ao final, a Assembleia já não tinha poder de decisão, porque era contraditória em si mesma - tal fato foi escancarado quando do pedido de revisão à Constituição por Bonaparte e os que o apoiavam, isso porque a mudança/revisão da Constituição, naquele momento, era sinônimo da manutenção de Bonaparte no poder. Quase três quarto dos votos foram favoráveis ao pedido, mas a Assembleia Nacional não aprovou a revisão, porque a Constituição exigia um quarto dos votos para vetar tal requerimento (e essa quarta parte, composta, em sua maioria, por republicanos, não queria a revisão da Constituição). Assim, a rejeição da revisão mostrou que a maioria Parlamentar queria a continuidade do chefe do Executivo, mas a Constituição não fora favorável ao Parlamento, mas àquela minoria parlamentar que votara contrariamente à sua mudança. Nas palavras de Marx:

Assim sendo, a maioria do Parlamento se declarou contrária à Constituição, mas essa Constituição se declarou favorável à minoria e considerou a sua decisão como válida. [...] Nesse momento, porém, a revisão da Constituição nada mais significava do que a continuidade do mandato presidencial, assim como a continuidade da Constituição nada mais significava do que a deposição de Bonaparte. O Parlamento se pronunciara a favor dele, mas a Constituição se pronunciara contra o Parlamento. Portanto, ele agiu no espírito do Parlamento quando rasgou a Constituição, e agiu no espírito da 
Constituição quando dispersou o Parlamento (MARX, 2011, p. 119).

Interessante observar também, que as disposições da Constituição aplicadas anteriormente tinham sido colocadas contra os sociais-democratas por votos majoritários do Parlamento. Isto é, uma contradição intrínseca, porque em determinados momentos, para alteração de direitos era necessário maioria do Parlamento, já em outro momento, apenas um quarto dos votos era necessário para vetar mudanças.

Por fim, deve-se compreender que os camponeses parceleiros ${ }^{27}$, que foi a grande massa que apoiou Bonaparte em seu golpe de Estado, pensava estar apoiando um agente messiânico que viria para salvar os franceses (como seu tio Napoleão outrora fizera, segundo eles), em prol do interesse geral da nação e em desfavor das demais classes da sociedade, que queriam o Estado apenas para si. Ocorre que, segundo Marx, esses camponeses, que conseguiram a propriedade privada das terras por meio do Código Civil Napoleônico, e romperam com o sistema feudal, agora apenas mudaram o tipo de exploração que recaía sobre eles. Enquanto no sistema feudal eram explorados por seus vassalos e senhores, agora o eram pelas grandes indústrias, pela alta e queda dos preços no mercado, pelos altos juros e hipotecas que eram obrigados a fazer para sobreviver - e a propriedade que era deles logo deveria ser alienada para pagamento de dívidas. Mas, o que ficava na mente dos

27 Esses camponeses eram grande parcela da sociedade francesa e conseguiram a consolidação de suas glebas com a Revolução Francesa. Contudo, eram pessoas pobres e com pouco intercâmbio social entre eles. A parcela era a unidade em que cada camponês com sua família produzia para própria subsitência (MARX, 2011, p. 142). 
camponeses eram os ideais burgueses, de que eles foram livres para decidir e que uma possível perda de terra dos camponeses e possível acumulação de outros agentes burgueses era erro daqueles que perderam suas glebas. Assim, Marx demonstra que, em realidade, os camponeses deveriam se juntar ao proletariado citadino para, construírem uma revolução capaz de emancipá-los das amarras daquele Estado e da burguesia que os oprimia e explorava (e não foi o que sucedeu naquela ocasião) porque a contradição dos interesses camponeses que existia era para com a burguesia, e não para com o proletariado (MARX, 2011, p. 146-154).

\section{CRÍTICA À DEMOCRACIA LIBERAL}

Esse estudo de Marx indica um antagonismo que há entre o Estado e a sociedade, que desemboca em "uma autonomia relativa do Estado e das classes politicamente dominantes" (POULANTZAS, 1977, p. 278). O Estado capitalista, como observado no bonapartismo, deixa de lado os interesses privadas e egoísticos dos indivíduos e, também, das classes dominantes em si. Ou seja, há uma certa independência do Estado em relação a essas classes. Como as instituições políticas desse Estado se movem em prol do povo-cidadão, observa-se certa autonomia em relação aos interesses econômicos das classes dominantes. Diz o autor:

A relação entre o Estado e o interesse político dessas classes, que Marx distingue inúmeras vezes do seu interesse "privado", "econômico", "egoísta”, etc., só se estabelece através de uma autonomia relativa do Estado e das classes, cujo segredo nos é desvendado pelo bonapartismo: a sua característica essencial é precisamente a independência particular do Estado em relação às classes 
dominantes (POULANTZAS, 1977, p. 278, grifos do autor).

Isso se torna claro quando se observa que a máquina estatal, a burocracia, é colocada então como bem geral do povo, interesse público, porque o que o Estado e seu aparelho estatal desejam são de interesse público e, assim, eles tomam conta de cada vez mais partes na sociedade, desde a construção de ferrovias, rodovias, hospitais, etc., em todas as partes aparece o Estado e ele se torna vontade geral (POULANTZAS, 1977, p. 141). Além disso, a ampliação desse aparelho estatal torna-se fundamental para Bonaparte porque, com ele, consegue encontrar cargos para seus apoiadores. Para Marx, e isso é de suma importância, o problema é que as revoluções ao invés de quebrar essa máquina, que vem desde os regimes absolutistas, elas aprimoraram-na.

Todas as revoluções somente aperfeiçoaram a máquina em vez de quebrá-la. Os partidos que lutaram alternadamente pelo poder consideraram a tomada de posse desse monstruoso edifício estatal como a parte do leão dos despojos do vencedor (POULANTZAS, 1977, p. 141).

Desse modo, uma das características que se deve pensar quando de um regime emancipador, e que poderia ser encontrado na essência democrática, seria a quebra com o aparelhamento da máquina estatal - e isso não quer dizer eminentemente quebra do Estado em si -, mas a mudança de como existe o Estado no modelo capitalista de ser, que é um Estado que, ao mesmo tempo em que é relativamente autônomo, nunca perde em sua essência a proteção aos interesses dominantes (burgueses) nem a proteção do Modo de Produção Capitalista. 
Mas, o Estado bonapartista não se interessou pela luta de classes, e se encontrava relativamente autônomo a ela, punindo tanto proletários quanto burgueses que fossem contra o Estado, exatamente porque ele representava o interesse geral, que estaria acima dessas "questões menores". Isto é, esse antagonismo e essa autonomia relativa se compõem em colocar interesses que seriam maiores que as classes que estão em constante lutas, mascarando a real luta de classes em um prol de um bem comum que, ao final, torna-se bem predominantemente burguês.

Podemos pois agora reter que esse termo de "antagonismo entre o Estado e a sociedade" indica, em primeiro lugar, no Marx da maturidade, a autonomia das estruturas respectivas do político e do econômico refletida na relação entre o Estado e a luta econômica de classe, mas também a autonomia relativa entre o Estado e as classes politicamente dominantes (POULANTZAS, 1977, p. 278).

Interessante perceber que, para Marx, essa unidade do Estado, mesmo que com certa autonomia em relação aos interesses econômicos da classe burguesa dominante tem a função de "criar a "unidade burguesa da nação" (POULANTZAS, 1977, p. 278). O Estado, então, é unidade, que se diz superior à nação e independente dela, mas na verdade, não consegue sobreviver sem a sociedade, até mesmo por ser ficção jurídica.

O bonapartismo é um bom exemplo do Estado capitalista em relação aos interesses políticos da classe dominante. Isso ocorre porque a burguesia dominante não poderia simplesmente atingir o poder sem uma ideia de nação, bem comum de todos, interesse geral, visto que 


\section{$\varphi \quad$ Filosofia, Engajamento e Sociedade}

haveria um desequilíbrio em relação à luta de classes, podendo ocasionar instabilidade e possibilidades de rupturas. O que ocorreu foi que o Estado-instituiçãocapitalista visando proteger os interesses da burguesia fragmenta os ideais burgueses colocando-os como bem geral de todos e interesse da coletividade, mascarando-se, assim, a luta de classes. Ou seja, quem é contrário ao Estado seria contrário à sociedade. Assim, a classe dominante

[...] não pode perpetuar as relações sociais existentes pela detenção do poder de Estado não através de toda uma gama de compromissos que mantêm o equilíbrio instável das classes presentes, senão através de toda uma organização política e um funcionamento ideológico particular, através dos quais consegue apresentar-se como representativa do interesse geral do povo e como encarnando a unidade da nação. Trata-se aí do papel do Estado capitalista em relação às classes dominadas, o que estebelece, aliás, a relação específica entre esse Estado e os interesses políticos das classes e frações dominantes (POULANTZAS, 1977, p. 279-280).

Ainda sobre $O 18$ de Brumário de Luís Bonaparte, cabe uma análise de Nicos Poulantzas (POULANTZAS, 1977, p. 287) sobre os Estados totalitários ${ }^{28}$, que afirma que o Estado capitalista extrai sua legitimidade por se apresentar como verdadeiro representante do bem comum, da nação-população. Enquanto no Estado absolutista, ou nos Estados anteriores, ele se apresentava, em realidade,

$28 \mathrm{O}$ autor fala principalmente dos Estados como o nazi-fascismo (século XX), mas há algumas semelhanças que poderiam ser encaradas nesta situação do golpe de Bonaparte, por exemplo, pelo embrutecimento do Estado e por se afirmar como interesse comum da sociedade. 
como "legitimidade divino-sagrada". Logo, a unidade apresentada pelo Estado através do povo-nação faz surgir, do mesmo modo, os Estados totalitaristas.

Por outras palavras, é exatamente o tipo de legitimidade do Estado capitalista, representando a unidade do povo-nação, que permite um funcionamento específico do Estado designado pelo termo de totalitarismo. Esse povo não é senão a expressão político-ideológica do efeito de isolamento, sobre os agentes, das estruturas ideológicas e políticas, efeito que as relações sociais econômicas manifestam. É possível, portanto, descobrir com facilidade os fenômenos reais ideologicamente designados pelo termo de massa (POULANTZAS, 1977, p. 287).

O Estado totalitário é possível pela relação "entre o princípio de legitimidade desse Estado e o isolamento do econômico" (POULANTZAS, 1977, p. 288). O isolamento causa tanto ocultamento de classe dos agentes quanto ausência da luta de classes nas instituições. Em outras palavras, os agentes que atuam no Estado totalitário não são confundidos com as classes dominantes ou a serviços dela ou de um Estado capitalista, mas são agentes a serviço da sociedade massificada. E, do mesmo modo, esses agentes, que não teriam classe, deixam clara a necessidade de ausência da luta de classes seja no plano institucional seja no plano real. Logo, os limites dessa luta no plano estatal-institucional em um Estado totalitário chegam a zero. Ou você é da massa-sociedade-nação, ou luta por uma classe e não faz parte da sociedade.

Vale destacar que o que ocasionou a ascensão de Bonaparte ao poder não foi um equilíbrio de forças entre as classes (seja entre burguesia e pequena-burguesia mais o campesinato, muito menos entre a burguesia e a classe 


\section{$\varphi \quad$ Filosofia, Engajamento e Sociedade}

operária), porque o proletariado tinha sido massacrado nos acontecimentos anteriores e foram perseguidos, sendo deixado de lado no cenário político social francês da época. O que se observa é uma contradição entre a "burguesia de um lado, a pequena-burguesia e o campesinato do outro" (POULANTZAS, 1977, p. 256), mas sem que haja efetivamente equilíbrio de forças, podendo haver, no máximo, uma "deficiência política 'momentânea' da força dominante tradicional” (POULANTZAS, 1977, p. 257). Dito de outra forma, a relação entre a classe hegemônica ${ }^{29}$ e as demais classes dominadas não se equilibra faticamente, porque a burguesia sempre terá sobre si o poder estatal, mas o que sucedeu no golpe de 1851 foi o famoso ditado "dar um passo para trás para dar dois a frente", porque o tom dado pela aparência é de que a "luta parece ter sido conciliada de tal modo que todas as classes se encontram de joelhos diante da culatra do fuzil, igualmente impotentes e caladas" (MARX, 2011, p. 140). Mas a essência demonstra que, apesar disso, o ideal burguês se fragmentava em todas as esferas da sociedade e continuava a ser aplicado pelo Estado e pelas demais classes de forma quase que inconsciente - a vontade da burguesia tornou-se vontade geral sem que os demais indivíduos percebessem.

Verifica-se, então, que a democracia liberal formada por meio de um Contrato Social com indivíduos iguais e no pleno gozo de suas liberdades nunca logrou êxito, apesar de Rousseau afirmar que a democracia verdadeira jamais poderia ser realizada no mundo fático. Contudo, conforme já explicitado, a formação do Estado nos moldes do Contrato, e da concepção liberal, já é suficiente para formar

${ }^{29} \mathrm{~A}$ burguesia, que as vezes pode pender para a burguesia fundiária, as vezes para a comercial, ou as vezes para a do capital financeiro. 
uma sociedade que possua todas as características essenciais para uma democracia, sendo que, se ela não chega a sê-lo, é por ocasiões de corrupção individual que barra os anseios da sociedade. Ocorre que o Estado é formado pela sociedade civil (ou pelos seres humanos) e, como tal, não se pode negar as contradições e lutas existentes no âmbito real dessa sociedade - e essa negação é o que o Estado Liberal deseja a todo momento. O método de Marx, com a consciência crítica de análise da realidade, mostra que esse Estado Francês de 1848-1852, representando um Estado Liberal, se colocava como um apaziguador (ou abafador) da luta de classes, e dos conflitos intrínsecos à própria sociedade capitalista, tentando demonstrar a todo momento para a massa da sociedade que esses conflitos haviam acabado - porque o interesse geral era o que reinava, e ele o fazia com ordem e paz. Isto é, todas aquelas pessoas que encontravam os conflitos da realidade social e tentavam transportá-los para questões de cunho estatal eram vistas como inimigos da sociedade, socialistas, comunistas, etc., e perseguidos. Isso tudo porque o Estado Liberal nunca retirou o véu que lhe encobre e que transmite aos seus súditos - ele não quis deixar de ser aparência para ser essência, visto que a essência da sociedade capitalista é relacionada à luta de classes, aos conflitos que são inerentes a ela.

Marx demonstra que a sociedade é muito mais complexa do que se quer tentar simplificar e apaziguar com a criação de um Estado Liberal. Ademais, afirma como uma classe pode se travestir de ideais revolucionários e valores emancipatórios apenas para seus próprios interesses assim como houve na França e na Inglaterra. Os franceses (na Revolução Francesa) se utilizaram das fantasias da 


\section{$\varphi \quad$ Filosofia, Engajamento e Sociedade}

Roma Antiga para provocar a revolução e depois deixá-la de lado, visto que não servia mais aos seus interesses.

Do mesmo modo, um século antes e em outro estágio de desenvolvimento, Cromwell e o povo inglês haviam tomado de empréstimo a linguagem, o fervor e as ilusões do Antigo Testamento em favor da sua revolução burguesa. Atingido o objetivo real, consumada a reestruturação burguesa da sociedade inglesa, Locke tomou o lugar de Habacuque (MARX, 2011, p. 27).

Pelo exposto em $O 18$ de Brumário, o filósofo alemão demonstra que o chamado bem geral, interesse de todos, segundo o qual o Estado legitima a si mesmo e suas ações, inexiste. O que ele faz é tomar o interesse de alguma classe ou grupo de indivíduos e torná-los interesse geral. Era assim que agia, por exemplo, o Partido da Ordem, que vendo-se maioria no Parlamento colocava em pauta e aprovava as perdas de direitos da sociedade.

Todavia, Marx mostra que para ascender a burguesia precisa das massas e, em seguida, precisa traí-las e destruir aquilo que lhe é incômodo - para que a propriedade privada e os negócios possam prosperar. O próprio Bonaparte foi eleito pelos pequenos camponeses, mas não conseguiu eliminar a miséria deles (MARCUSE, 2011, 12) visto que eles apenas transitaram nas mãos de quem os explorava. Sendo assim, é inegável que a chegada de Bonaparte ao poder da França, por meio de um golpe, não foi, em realidade, um desvio de finalidade do Estado Liberal burguês, ou da democracia pensada nos moldes burgueses. A essência do ato vai muito além, visto que quando ameaçados propriedade privada, negócios e interesses privados, todos os direitos civis construídos 
generalizadamente podem ser extirpados - até mesmo para os burgueses. É dizer:

A generalização e a realização da liberdade não são mais do interesse da burguesia; isso já é "socialismo". [...] A classe dominante se mobiliza para liquidar não só o movimento socialista, mas também as suas próprias instituições, que entraram em contradição com o interesse da propriedade e do negócio: os direitos civis, a liberdade de imprensa, a liberdade de reunião, o direito ao sufrágio universal foram sacrificados a esse interesse para que a burguesia pudesse, "sob a proteção de um governo forte e irrestrito, dedicar-se aos seus negócios privados (MARCUSE, 2011, p. 11).

\section{POR UMA COMPREENSÃO DE ESSÊNCIA DA DEMOCRACIA NO PENSAMENTO DE MARX}

Para compreensão do que é a verdadeira democracia em Marx, não se pode abrir mão de seu método do materialismo histórico-dialético e do rompimento com um de seus mestres, Hegel. Isso porque Marx vê no Estado e na sociedade uma contradição essencial cuja mediação não pode suprimí-la, mas apenas acobertá-la. Assim,

Quando a democracia atinge sua verdade, ela se supera, encontrando sua real expressão no processo de desvanecimento do Estado e da sociedade civil única solução possível para dois extremos reais que, enquanto tais, não admitem mediação. Com a superação destes, o político encontra-se definitivamente com o social, e nenhuma relação de subordinação ou dependência passa a ser possível entre um e outro. No entanto, a realização da democracia foi modernamente concebida na forma de um 'Estado democrático': uma aliança impertinente entre dois termos inconciliáveis (POGREBINSCHI, 2009, p. 207); 


\section{$\varphi \quad$ Filosofia, Engajamento e Sociedade}

Em outras palavras, a democracia se dá quando sociedade e Estado desaparecem, e isso ocorre quando um e outro tornam-se indiferentes. A política passa então a fazer parte do próprio homem como ser humano, e não do homem como cidadão, que precisa do Estado para garantia de seus direitos. Essa garantia de direitos não deve vir, portanto, de um ente superior denominado Estado, que salva os direitos dos seres humanos, mas do próprio ser humano - por ser humano a sua humanidade é garantida. Os conceitos e valores a serem defendidos, portanto, serão trabalhados pelos próprios indivíduos em comunidade.

Com isso, Thamy Pogrebinschi afirma que as falsas democracias, que se dizem democracias, compõem o Estado em uma forma política que não é democrática sejam elas a monarquia, aristocracia ou república - e que, em realidade, estão em oposição ao que seria uma verdadeira democracia (POGREBINSCHI, 2009, p. 208). O pensamento de democracia em Marx deve ser para fora e para além do Estado, não podendo se enquadrar aos conceitos modernos tanto de Estado quanto de democracia.

Ainda criticando Hegel, Marx salienta que a democracia deve unir o universal ao particular, o Estado à sociedade civil. Apenas com a união dos dois extremos é que a democracia como essência pode ser compreendida - e, essa união só seria realizável na comunidade, sendo que o único conteúdo possível de preenchê-la é a democracia. Logo, entende-se que a comunidade sem democracia não se faz comunidade e a democracia cuja forma não seja a comunidade não se fará democracia verdadeira. Dito de outro modo,

A verdadeira democracia, por conseguinte, consiste no momento da união entre o universal e o particular; no momento da fusão das esferas 
política e social; no momento do reencontro entre o indivíduo egoísta da sociedade civil e o cidadão abstrato do Estado. O lugar em que o dualismo abstrato da modernidade se resolve e os extremos reais se reunificam é a comunidade (POGREBINSCHI, 2009, p. 211).

Não se pode esquecer do caráter histórico do método marxiano e, assim sendo, a democracia em sua essência não pode ser estática, ou aprisionada em um ideário ou determinada instituição; ela deve ser fruto dos seres humanos que compõem determinada comunidade em um determinado contexto histórico-social, sob risco da essência se promiscuir na aparência e esta manter-se escondendo a realidade. Neste caso,

A experiência dos sujeitos na comunidade não pode ser aprisionada em construções jurídicas artificiais. É natural que Marx as tome, portanto, como abstrações e não lhes dê senão o valor de uma ilusão. Ilusões que surtem efeitos na realidade, certamente; mas ilusões. [...] Marx irá substituir a noção de soberania pelo conceito de autodeterminação e, no lugar de representação, proporá o autogoverno (POGREBINSCHI, 2009, p. 220).

Neste cotejo, as ficções jurídicas, como o Contrato Social e os demais aparelhos do Estado, segundo os quais as sociedades modernas só trataram de inflar e aperfeiçoar - conforme se verifica no próprio golpe de Bonaparte, em que tratou de aperfeiçoar a máquina estatal para que a mesma pudesse atingir seus objetivos e manter a dicotomia entre Estado-sociedade, tão importante para o Estado Liberal - não passam de ideologias, falsas percepções da realidade. Ilusões que, por mais fantasioso que seja, causa 


\section{$\varphi$ Filosofia, Engajamento e Sociedade}

efeitos concretos no mundo dos fatos. Dessa forma, o entendimento sobre a democracia deve partir do ser humano, do viver humano, consoante seu agir e sua vida não seria possível a dissociação do agir humano com o ser humano. O humano seria o que ele realmente é - e não apenas o que ele pensa.

É por isso que a democracia parte do homem: ele é o sujeito da democracia, o que equivale a dizer que ele é o seu conteúdo. A democracia identifica-se com a experiência do homem, com sua atividade, com sua prática, com sua vida (POGREBINSCHI, 2009, p. 214).

Acontece que, no trato com o Estado, a modernidade tratou de separar as formas estatais de seus conteúdos.

Afinal, em todas essas formas de governo só se pode ter uma 'democracia política' - o que equivale a dizer uma democracia liberal, burguesa; uma democracia enquanto abstração: uma 'democracia moderna' (POGREBINSCHI, 2009, p. 212).

Isto é, o Estado moderno se encontra presente apenas em formas diferentes de governo, sendo que seu conteúdo, independentemente, é "democraticamente burguês". Porque, seja em uma monarquia, aristocracia ou tirania, não haverá diferenciação da essência do sistema, que será burguês, cujos ideais e propagação dos ideais são burgueses. E é por isso que o que aconteceu na França do 18 de Brumário não é um desvio de uma democracia liberal propriamente dita - porque houve a mudança das formas de governo, de um republicano se passou para um autoritário/tirano, contudo, o conteúdo permanece "democraticamente burguês". Veja bem, não se trata de um desvio ao Estado Liberal democrático burguês, visto que é 
um reequilíbrio das estruturas ${ }^{30}$ que mantêm o sistema capitalista.

Sobre a verdadeira democracia, sua essência, deve-se dizer que ela

[...] é um conteúdo sem forma determinada, um conteúdo que não pode ser traduzido por outra forma senão a desse próprio conteúdo. Por isso a democracia pode ser concebida em seus próprios termos, pois que é ao mesmo tempo forma e conteúdo. Uma monarquia pode ser democrática, assim como também pode uma república, mas uma democracia não é ela mesma uma democracia monárquica ou uma democracia republicana: a democracia é a verdade da monarquia (como poderia ser a verdade da república), mas a monarquia não é a verdade da democracia. A monarquia ou a república são apenas formas que falsificam o conteúdo, isto é, falsificam a democracia (POGREBINSCHI, 2009, p213).

Em outras palavras, a democracia é um conteúdo cuja manifestação real dela só pode ser ela mesma, enquanto a monarquia e outras formas são desprovidas de conteúdo podendo, inclusive, se preencher com o conteúdo democrático. Contudo, esse preenchimento da matéria na forma não-material (que não tem correlação com o conteúdo em si) falsifica a própria matéria em si, tornandoa não mais democracia verdadeira, mas mera aparência de democracia, uma falsa percepção da realidade. Assim, a

3o Pensadas em um sentido amplo, seja como as instituições que compõem o Estado, sejam os ideários capitalista que estão em ruínas e precisam de um Estado forte para serem implantados na mente da sociedade, ou seja porque as taxas de lucro e comércio, assim como os demais interesses privados, não estão nos níveis satisfatórios. 
única forma possível para a plenitude da democracia possa se manifestar é a comunidade.

Pois a comunidade, afinal, organiza-se a partir da ideia de associação, ou seja, por meio de uma relação intrínseca entre as partes e o todo, entre a forma e o conteúdo. Com a democracia, a comunidade forma um uno múltiplo, em que a relação de todas as partes com o todo é indissociável e é nessa inseparabilidade que elas se reconhecem (POGREBINSCHI, 2009, p. 217).

A essência da democracia deve ser pensada levandose em consideração, dentre outras, duas características, quais sejam: a autodeterminação ${ }^{31}$ e o autogoverno - que são necessárias para substituir os estudos relativos à soberania e à representação.

A autodeterminação seria um contraponto à ideia de soberania. Inicialmente, deve-se compreender que a soberania é uma ficção jurídica, assim como o Estado o é, e serve para separá-lo da sociedade civil. Deste modo, a soberania não passa de uma abstração que possui efeitos na realidade. Mas, consoante o método marxiano, deve-se ir além da aparência observada - e é assim que se encontra a autodeterminação. Isso porque a soberania popular, conforme observada na modernidade, se reduz à

31 A autodeterminação é observada em diversos diplomas jurídicos, tanto na Carta das Nações Unidas, quanto na Constituição de 1988 da República Federativa do Brasil, e talvez o conceito seja semelhante daquele que será explicitado nesta tese, todavia, trata-se de uma garantia (supra)estatal cuja eficácia não tem correlação com a realidade em si. Essa garantia, na maioria das vezes se mantem no campo da aparência. No entanto, a análise desses diplomas legais com a realidade não será tratada aqui - o importante é saber que já existe uma certa noção do que seja esse conceito. 
capacidade do povo de formar e reformar suas próprias instituições, ou criar e alterar constituições como bem entender, formar poderes constituintes derivados ou originários - sendo que ela não pode ser apenas isso, ela deve ser muito mais (POGREBINSCHI, 2009, p. 222). É por isso que o conceito de autodeterminação é importante, porque

Não basta ao povo existir; para ser real ele tem que intervir diretamente na realidade, constituindo-a, fazendo dela parte de si mesmo uma vez em que ela também se organiza de acordo com a ação dos homens. A forma política que resulta dessa organização não pode ser senão uma criação própria do povo, um resultado de sua capacidade de determinar a si mesmo. Enquanto 'criação livre do homem', a democracia prescinde de formas jurídicas (POGREBINSCHI, 2009, p. 224).

Sendo assim, a autodeterminação se faz em um processo, em ação, em uma atividade do sujeito de se autodeterminar e, ao mesmo tempo, de determinar o ambiente e as relações sociais para com as quais ele vive. Com isso, a própria conceituação de cidadania muda, já que, na relação com o Estado é que o indivíduo torna-se cidadão, isto é, ao cumprir os deveres impostos por aquele Estado ao qual se encontra e possui vínculo (vínculo este de caráter jurídico-ficcional). $\mathrm{O}$ que a autodeterminação propõe é a quebra desse vínculo, porque o Estado e sociedade civil não são dissociados, porque a pessoa é cidadã simplesmente por sê-lo, as suas práticas de vida são atos políticos e geram suas características de cidadão. Nas palavras da autora, "[...] toda atividade humana, todas as ações do homem, são constitutivas da cidadania. Em outras 


\section{$\varphi \quad$ Filosofia, Engajamento e Sociedade}

palavras, toda atividade humana é preenchida de sentido político" (POGREBINSCHI, 2009, p. 224).

Entende-se então que, para haver autodeterminação, não se pode separar, tampouco, a esfera particular da pública nas ações humanas, porque toda ação possui efeitos e tende a ter características sobre a comunidade, sendo assim, um ato político.

Já no que concerne ao autogoverno a proposta está justamente em o ser humano governar a si mesmo e, assim, governar a própria sociedade que o cerca. Por ser dono de si mesmo o próprio ser humano consegue, através do autogoverno governar o que é melhor para a comunidade em comunidade. Dessa forma, "na medida em que cada homem governa a si mesmo, ele está governando a comunidade. Sua ação individual, afinal, é sempre uma ação pública, com efeitos políticos" (POGREBINSCHI, 2009, p. 230).

Representação também pode ser encarada como uma ficção jurídica, que não possui relação com a realidade visto que o próprio representante não necessariamente representa o representado. Assim, de forma resumida podemos dizer que a participação no Estado moderno se dá por meio de pré-requisitos ou requisitos - que cumpridos fazem o ser humano tornar-se cidadão. Mas, somente aqueles escolhidos podem ajudar nas deliberações e decisões do Estado e, mais, ele deve ser cidadão (POGREBINSCHI, 2009, p. 232). Ou seja, há uma duplicidade de requisitos necessários para se atuar e/ou decidir dentro do Estado moderno. Na real democracia isso não pode proceder, visto que isso é contrário à própria liberdade em si - porque se o homem só pode atuar/decidir no Estado necessitando desses (pré)requisitos não há liberdade para se atuar no Estado, ele se torna instrumento 
de não-liberdade. O ser só poderá atuar se preencher o que lhe é determinado, fora do qual, não preenchido, ele será um ser humano, mas cujo o qual não interfere no Estado em que vive.

Vale ressaltar que Marx, após 1844, altera a nomenclatura de verdadeira democracia e passa a se utilizar do termo comunismo (já que a forma é a comunidade e o conteúdo deve ser democracia, visto que interdependentes entre si, a mudança na terminologia fazse interessante) - apesar do significado permanecer o mesmo no pensamento do autor. Ademais, há mudança em relação ao conceito de povo, para o proletariado, como o ser humano agente das mudanças que podem ocasionar a democracia, o sujeito político marxiano (POGREBINSCHI, 2009, p. 272).

Dito isto, importante ressaltar que a verdadeira democracia, ou comunismo, é uma prática do ser humano para o ser humano, é uma prática de quebra com as falsas percepções da realidade que cercam o humano para se verificar a essência das coisas e, tem como características, dentre outras, tanto a autodeterminação - em que o sujeito deve ser o ser de sua própria criação - e do autogoverno em que os seres humanos devem ser livres para deliberar e mudar os rumos de sua própria comunidade.

\section{CONCLUSÃO}

Por todo o exposto neste trabalho, foi possível verificar o método filosófico marxiano de análise da realidade, com o materialismo histórico-dialético, compreendendo como o filósofo alemão Karl Marx conseguiu chegar a esse entendimento perpassando desde Feuerbach à Hegel. 


\section{$\varphi \quad$ Filosofia, Engajamento e Sociedade}

Depois, observou-se o pensamento dos autores liberais da modernidade, que pensaram o contrato e a sociedade civil nos moldes de um Contrato social, sendo eles Locke e Rousseau. Por meio deles vieram à tona conceitos como contrato social, estado de natureza e representação.

Em seguida, verificou-se o pensamento de Marx na crítica do golpe de Estado ocasionado por Luís Bonaparte à França, na metade do século XIX. Sendo assim, e com base em seu método de análise da realidade, o filósofo verifica um membro da nobreza, que fora eleito pela maioria dos votantes, conseguiu realizar um golpe de Estado contra a burguesia e as demais camadas da sociedade, em prol de um interesse geral, mas que, ao final, desenvolveu os interesses da própria burguesia, ajudando a consolidar o seu sistema.

Neste cotejo, constata-se que as ditaduras burguesas e os autoritarismos, diferentemente do que pensa o entendimento liberal, não são desvios de finalidade do Estado burguês liberal moderno, mas reorganizações do sistema para melhor implementação do modo de produção, para manutenção das taxas de lucro, para perpetuação de seus ideais ou até para a retirada de outros ideais do pensamento social. Ou seja, na democracia liberal moderna, independe quem irá "tomar" o poder do Estado porque o mesmo sempre terá ideário burguês, será sempre um Estado burguês, com a manutenção do sistema. Sendo que, o máximo que pode acontecer é uma certa melhoria para determinada classe além da classe burguesa (que sempre será beneficiada - direta ou indiretamente).

Então, com os estudos da autora Thamy Pogrebinschi observou-se uma forma de se pensar a verdadeira democracia no pensamento de Marx. Para tanto, se chegou 
a dois conceitos fundamentais que devem existir, além de outros, que são a autodeterminação e o autogoverno. Com esses conceitos e com os estudos da autora sobre Marx, percebeu-se que a democracia é, também, uma prática, uma ação humana de se fazer o humano. Sendo assim, pode-se dizer que há um agir democrático que também deve ser analisado no pensamento de Marx.

Por fim, e talvez o mais importante, entendeu-se que o método filosófico de Marx é fundamental para a compreensão de qualquer fenômeno, seja político, seja econômico, seja social, ou qualquer outro. E, é por esse método filosófico marxiano, conforme foi estudado, que se verifica a real importância da filosofia para o mundo. Em outras palavras, esta monografia demonstrou que a não utilização de um método crítico de análise da realidade, e sem a própria filosofia, corre-se o risco do pensamento permanecer na superficialidade e simplicidade de atos, sem que seja possível alcançar o verdadeiro fenômeno - com todos seus interesses, conflitos, contradições e disputas que estão em jogo.

Assim, o método filosófico pesquisado mostrou-se um excelente meio para se compreender a realidade, transpondo-se o traçado da superficialidade e da mera aparência, com a possibilidade de se chegar à essência dos atos e ao real entendimento do que está acontecendo, ou o que aconteceu. E, ao ter o conhecimento real sobre o mundo ao seu redor é possível ser agente de mudança.

\section{REFERÊNCIAS}

FEUERbaCH, Ludwig. Princípios da Filosofia do Futuro e outros escritos. Lisboa: Edições70, 2002, trad. Artur Morão. 


\section{$\varphi \quad$ Filosofia, Engajamento e Sociedade}

HEGEL, Georg Wilhelm Friedrich. Princípios da Filosofia do Direito. 2 ed. São Paulo: Ícone, 1997, trad. Norberto de Paula Lima.

LABORDA, Antonio Igea. Las influencias de Hegel y Feuerbach en la primera obra teorica de Marx. Revista de Estudios Políticos (Nueva Epoca). N. 22, JulioAgosto, 1981, p. 185-212. Disponível em: <https://marxismocritico.files.wordpress.com/2011/12/re pne_022_184.pdf>. Acesso em 20 nov. 2016.

LOCKE, John. Segundo Tratado Sobre o Governo Civil. Trad. Magda Lopes e Marisa Lobo da Costa. 3 ed. Petrópolis: Vozes, 2001.

MARCUSE, Herbert. Prólogo. In.: MARX, Karl. O 18 de Brumário de Luís Bonaparte. Trad. Nélio Schneider. São Paulo: Boitempo, 2011.

MARKOVIC, Mihailo. El marxismo contemporáneo. Madrid: Fonde de Cultura Economica, 1978.

MARX, Karl. Crítica da Filosofia do Direito de Hegel. 2 ed. Trad. Rubens Enderle e Leonardo de Deus. São Paulo: Boitempo, 2010.

. O 18 de Brumário de Luís Bonaparte. Trad. Nélio Schneider. São Paulo: Boitempo, 2011.

. O capital: crítica da economia política: Livro I. Trad. Rubens Enderle.São Paulo: Boitempo, 2013. 
POULANTZAS, Nicos. Poder político e classes sociais. Trad. Francisco Silva. Rev. Carlos Roberto F. Nogueira. São Paulo: Martins Fontes, 1977.

PERTILLE, José Pinheiro. Aufhebung, meta-categoria da lógica hegeliana. Revista Eletrônica Estudos Hegelianos. Ano 8, n. 15, Dezembro, 2011, p. 58-66. Disponível em: <http://www.hegelbrasil.org/reh_2011_2_art4.pdf>. Acesso em 20 nov. 2016.

ROUSSEAU, Jean-Jacques. Do Contrato Social. Coleção Os Pensadores, vol. I. Trad. Lourdes Santos Machado. São Paulo: Nova Cultura, 1999.

SILVA, Marlon Garcia da; EVANGELISTA, Rodrigo Prado. A ruptura de Marx com a filosofia idealista na década de 1840. In: I Seminário de Crítica da Economia Política: questões contemporâneas, 2012, Teófilo Otoni. Anais ISSN 2238-5371. Teófilo Otoni: SECEP, 2012, p. 1-14.

POGREBINSCHI, Thamy. O enigma do político: Marx contra a política moderna. Rio de Janeiro: Civilização brasileira, 2009. 
Q Filosofia, Engajamento e Sociedade 


\section{A RELIGIÃO COMO MELHORAMENTO DAS INTENÇÕES MORAIS EM IMMANUEL KANT32}

Fabrício Silva de Almeida

O objeto deste texto é mostrar que, em Kant, a verdadeira religião é a religião moral. Essa recondução da religião à moral levou Kant a propor uma distinção entre fé histórica e fé racional e a fazer uma crítica severa à religião de sua época. Essa crítica se dá no âmbito de um contexto pautado pela forte influência do racionalismo iluminista que clamava pela independência da moral racional em relação à teologia. O papel do esclarecimento, na concepção de religião proposta por Kant, mostra que a verdadeira religião faz parte de um processo em que deve imperar a autonomia. Por esse motivo, Kant rejeita a religião revelada, uma vez que nela o comando divino é imposto ao homem. Ele adota a religião racional em que o homem, sob uma perspectiva prática, sabe o seu dever e, ciente disso, o considera como mandamento divino. Isso quer dizer que a religião torna-se o resultado de exigências morais e não apenas o resultado da adoção e da observância de estatutos e credos. Wood (2008, p. 213) mostra que Kant era profundamente desconfiado das práticas religiosas e muito hostil ao domínio que o poder clerical exercia sobre a mente das pessoas. No entanto, diz ele, Kant “[...] não era hostil

32 Monografia apresentada, em 19/12/1027, ao Departamento de Filosofia da Universidade Federal do Espírito Santo, como requisito para obtenção do grau de Graduado em Filosofia. Orientação: Prof. Dr. José Pedro Luchi. Banca: Prof. Dr. Antônio Vidal Nunes; Prof. Dr. Lúcio Vaz de Oliveira (UFES). 


\section{$\varphi \quad$ Filosofia, Engajamento e Sociedade}

em relação àquilo que considerava ser a verdadeira religião" (WOOD, 2008, p. 213). A função da verdadeira religião é conduzir os seres humanos para a melhoria moral coletiva da raça humana, em contraste com as formas passadas de religião que surgiram do medo supersticioso, de uma formação escrava da mente e da ambição cruel dos sacerdotes em sujeitar a vida interna dos homens à sua tutela tirânica.

Assim, o objetivo da primeira parte, tomando por base uma abordagem mais racional, é mostrar como Kant chega ao conceito de religião. Mostrarei que é por meio da ideia de fins da razão, especificamente pelo conceito de sumo bem, que Kant, apesar de mostrar que a moral não precisa de nada além de si mesma como fundamento, afirma chegar ao conceito de religião. $\mathrm{O}$ sumo bem, possível união entre virtude e felicidade, pressupõe a ideia de um legislador supremo capaz de unir esses dois elementos, constituindose como via principal para que a moral possa conduzir inevitavelmente à religião. O objetivo central é mostrar como Kant fundamenta a religião em argumentos morais, mostrando como a moralidade, que é fundamentalmente independente da crença religiosa, leva ao conceito de religião, considerada por ele como "[...] o conhecimento de todos os nossos deveres como mandamentos divinos" (KANT, 2008, p. 155). A lei moral compreendida como mandamento divino nos remete à ideia de um ser santo que possui uma vontade totalmente adequada à lei moral. Isso nos leva ao pressuposto fundamental de que a religião se torna, por assim dizer, o resultado de reivindicações morais e não de regulamentos doutrinários. É a disposição de observar todos os deveres como mandamentos divinos, subtendendo-se, dessa forma, que a religião tem a ver com as intenções, isto é, com a prática e não com o 
conhecimento do que seja Deus, Cristo ou qualquer outro conceito tomado como fim em si mesmo.

No entanto, para Kant, a natureza humana não é "[...] assaz robusta para a observância dos princípios [...]" (KANT, 2008, p. 43). Isso porque existe uma propensão natural para o mal moral na natureza humana. Por isso, na segunda parte, num âmbito mais antropológico, tratarei do conceito de mal radical, que consiste em um reviramento na ordem hierárquica dos móbiles da vontade que corrompe o fundamento das máximas. Quando o homem coloca como máxima do seu agir outro princípio que não seja o comando da lei moral, ele se torna mal. Por isso, precisa passar por uma revolução, que Kant chamou de revolução da consciência. Ele precisa sair do mal que adotou por um ato de liberdade e rumar para o bem do qual se afastou. No entanto, mesmo que o homem passe por uma revolução moral na sua consciência, suas ações jamais serão totalmente adequadas à lei. Isso quer dizer que por mais que o homem, por uma revolução de sua consciência, tome a lei moral como horizonte de determinação de suas ações, a sua vontade jamais será totalmente adequada ao comando da lei, pois somente um ser santo possui tal prerrogativa. Isso, então, gerou um abismo que Kant tenta resolver mostrando que a natureza humana precisa estar em constante reforma gradual e que os conteúdos religiosos, para ajudar o homem nessa empreitada, precisam acenar para conceitos morais.

O problema do mal pode será analisado em torno de três perguntas fundamentais, quais sejam: como pode o homem sair do mal e torna-se bom? Como resolver o problema do mal radical? Como a religião pode oferecer recursos para a solução dessa questão? Entregar-se com todas as forças ao mandamento moral não é uma tarefa fácil 


\section{$\varphi \quad$ Filosofia, Engajamento e Sociedade}

para o homem, devido à sua natureza afetada por impulsos sensíveis, que servem como empecilhos para que a lei moral seja sempre colocada como princípio supremo de suas máximas. Por isso, mediante o conceito de mal radical, Kant descreve a ruína moral humana. O que está jogo aqui não é somente que o homem saia do mal e se torne legalmente bom, mas que se torne moralmente bom. Isso significa que ele precisa ser virtuoso do ponto de vista moral. Precisa estar com sua disposição moral em luta segundo o seu caráter inteligível, agindo por dever e não somente conforme o dever. A religião, por esse motivo, precisa oferecer meios pelos quais o homem possa tanto sair do mal e progredir para o bem, entendido como melhoria moral, quanto para desenvolver suas predisposições moralmente boas e, assim, o ajudar na reforma gradual de sua natureza.

Por isso, é no campo religioso que Kant enxerga um modelo moral para se seguir. Um exemplo intuível de uma conduta moralmente boa, personificada na encarnação do filho de Deus em Jesus Cristo, como um arquétipo da humanidade agradável a Deus pela sua conduta moral da vida.

Dando continuidade à reconstrução da proposta kantiana de que a religião pode contribuir para a melhora moral do homem, analiso, na terceira parte, o conceito de comunidade ética, que Kant entende como uma convocação recíproca de aperfeiçoamento moral coletivo. Isso se dá porque ainda que o homem tenha um arquétipo para a sua conduta moralmente boa e passe por uma revolução moral tomando a lei moral como máxima das suas ações, ele precisa estar engajado em uma sociedade que contribua para sua evolução moral. Sobre essa questão Ferraz afirma que "[...] a religião é, assim, derivada do caráter social do 
sumo bem do homem" (FERRAZ, 1991, p. 145). Kant entende que "[...] o império do princípio bom, na medida em que os homens para ele podem contribuir, só é alcançável [...] mediante a ereção e a extensão de uma sociedade segundo leis de virtude [...]" (KANT, 2008, p. 100). O homem precisa estar engajado socialmente em prol do progresso moral, uma vez que sozinho não poderá progredir moralmente, dado que a sociedade em que está inserido exerce uma influência fundamental em sua conduta. Por esse motivo, Kant afirma que "[...] o bem moral supremo não é realizado apenas mediante o esforço da pessoa singular em ordem à sua própria perfeição moral, mas exige uma união das pessoas num todo em vista do mesmo fim" (KANT, 2008, p. 104). Com essa ideia Kant projeta um estado de convivência humana onde todos observam a lei moral. Esse inteligível reino dos fins somente se torna um reino desse mundo quando é pensado como realizável não apenas individualmente, mas de modo cooperativo no mundo dos fenômenos.

$\mathrm{Na}$ última parte analiso a questão da religião verdadeira e o falso culto, tomando como pressuposto fundamental a ideia de que, para Kant, "[...] há somente uma (verdadeira) religião [...], a religião da razão" (KANT, 2008, p. 113). A verdadeira religião é uma religião pura, racional, que não é pautada nos conteúdos da fé eclesial, mas é alicerçada somente na razão. Kant dá continuidade à temática da fundação de um reino de Deus, mostrando, no interior desse reino, o que é lícito e o que não é lícito em prol da moralidade. Dessa forma, ele efetua sua crítica, sob a alegação de que a religião estatutária não desempenha e nem admite sua verdadeira função. Essa crítica é construída a partir da distinção entre verdadeiro e falso culto, apoiada no argumento de que o elemento peculiar de 


\section{$\varphi \quad$ Filosofia, Engajamento e Sociedade}

toda religião racional é o aperfeiçoamento moral do homem, mostrando, assim, o seu lado construtivo ao apontar para o estímulo à moralidade.

Por isso, o objetivo de Kant é analisar um possível acordo entre a religião estatutária e os enunciados de uma fé puramente moral, uma fé fundamentada nos princípios da razão. Sua crítica aos símbolos da religião positiva visa colocá-los sob o crivo da razão, livrando o praticante de fanatismos, de uma observância cega aos meros estatutos eclesiais e do falso culto dotado de rituais. $\mathrm{O}$ praticante pensa que assim se pode agradar a Deus, mas no entender de Kant, "[...] não é a observância de deveres civis externos ou deveres eclesiais estatutários, mas apenas a pura intenção do coração que pode tornar o homem agradável a Deus" (KANT, 2008, p. 161).

O erro da religião está no fato de que nas suas supostas tentativas de agradar a Deus, frequentemente, encoraja não a conduta moralmente boa, mas meras observações doutrinais, o que leva Kant a perguntar: “[...] como é possível, de acordo com a razão (pura e teórica), o sistema eclesial da dogmática nos seus conceitos e enunciados doutrinais?” (KANT, 2008, p. 22). Por isso, a religião nos limites da simples razão diz respeito à análise do fenômeno religioso e sua submissão aos ditames da razão, com o objetivo de chegar a uma religião racional, que possui como verdadeira função a moralização do homem.

O homem comum entende sempre por religião a sua fé eclesial que se lhe apresenta aos sentidos, ao passo que a religião é interiormente oculta e depende das disposições de ânimo morais. À maior parte das pessoas concede-se honra excessiva ao dizer a seu respeito que professam esta ou aquela religião; de fato, não conhecem nem exigem 
nenhuma; a fé eclesial estatutária é tudo o que eles entendem por tal palavra (KANT, 2008, p. 114).

Pelo fato de o homem entender por religião apenas sua fé eclesial e não uma fé que depende de disposições morais, a verdadeira religião precisa ser erigida, pois o progresso moral da raça humana se dá, também, por meio do avanço da religião no cumprimento de sua vocação própria. Essa vocação vem da premissa fundamental de que a religião da razão precisa remeter a conceitos racionais e, como tem a ver com a ação, precisa remeter também a conceitos práticos morais, contribuindo para a promoção de disposições de ânimo moralmente boas.

No entanto, é necessário explicar que o termo "disposição de ânimo" (Gesinnung), que significa o "primeiro fundamento subjetivo da adoção das máximas" (KANT, 2008, p. 31), pode ser entendido também de outra forma. Fazer essa diferenciação é de suma importância para este trabalho, pois, do contrário, dificultaria o entendimento do estudo.

Na tradução portuguesa de $A$ Religião nos Limites da Simples razão, o termo "disposição" equivale a dois sentidos diferentes. Pinheiro (2005, p. 371) explica que "[...] o conceito kantiano de intenção decorre do termo alemão Gesinnung, que pode ser traduzido tanto por "disposição de ânimo" quanto por "intenção"”. Ela mostra que a tradução portuguesa, feita por Artur Morão (Edições 70), optou por traduzir Gesinnung por "disposição de ânimo”. Já Tânia Maria Bernkofp (Coleção os Pensadores) traduziu como "intenção" e na tradução francesa o termo aparece como "atitude". Pinheiro (2005) entende que a melhor alternativa seria optar por "intenção". Isso porque, dessa forma, se evita qualquer associação com o conceito de 


\section{$\varphi$ Filosofia, Engajamento e Sociedade}

disposição para o bem (Anlage zum Gutem). A diferença está em que, enquanto disposição originária (Ursprüngliche Anlage) como veremos mais à frente, é sempre objetiva podendo ser desviada, a intenção (Gesinnung) é subjetiva podendo ser melhorada.

Acontece que na tradução portuguesa, adotada neste estudo, o tradutor usou o termo "disposição" ora para Gesinnung ora para Anlage. Mas, como visto, temos aí significados diferentes. Gesinnung se refere ao modo de pensar, ao conjunto intenções subjetivas que o sujeito adota e que pressupõe autonomia. Já Anlage se refere à disposição que é originária. Refere-se à disposição no sentido de "instalação", na medida em que é intrínseca ao homem33.

Um exemplo disso é "a disposição para a personalidade moral", que "é a susceptibilidade da reverência pela lei moral" (KANT, 2008, p. 33). O termo disposição usado aqui é Anlage, pois, como Kant (2008, p. 43) mesmo explica, é uma disposição que pertence à "[...] possibilidade da natureza humana”, de modo que, ainda que haja no homem uma propensão para o mal, essa disposição jamais é extirpada porque é constitutiva da natureza humana.

Mas quando o homem, por um ato de liberdade, toma a lei moral como máxima das suas ações, saindo do mal e rumando para o bem do qual se afastou, por meio da revolução moral de sua consciência, passando a ter, por isso, uma nova "disposição de ânimo", o termo usado para

33 Como o tradutor da edição portuguesa não fez essa diferenciação, apontarei, sempre que for necessário, a diferença de Anlage e Gesinnung dentro do texto. 
"disposição" nesse contexto é Gesinnung e não Anlage. Refere-se ao "[...] primeiro fundamento subjetivo da adoção das máximas” (KANT, 2008, p. 31), intencionalmente adotado pelo sujeito, que pode ser entendido também como "intenção".

Assim, foi preciso fazer essas considerações para tornar clara a aplicação desses termos no texto. Isso porque o termo "intenção", que às vezes aparece como "disposição de ânimo", é significativo para este trabalho, na medida em que o objetivo é exatamente tratar da contribuição da religião na melhoria das intenções morais.

\section{PRIMEIRA PARTE}

\section{Os fins morais da razão}

No prólogo à primeira edição da Religião nos Limites da Simples Razão, Kant afirma que "[...] a moral, em prol de si própria, [...] de nenhum modo precisa da religião, mas basta-se a si própria em virtude da razão prática" (KANT, 2008, p. 11). Nota-se que a razão prática não se fundamenta na religião. Pelo contrário, é a fé religiosa que deve se fundar na moralidade, pois a moral não depende da crença religiosa para se fundamentar.

Isso já era evidente na Fundamentação da Metafísica dos Costumes, onde Kant procurou mostrar que o princípio supremo da moralidade funda-se na autonomia34 da razão e nada além dela pode se constituir como fundamento da

34 Segundo Kant: “Autonomia da vontade é aquela sua propriedade graças a qual ela é para si mesma a sua lei (independente da natureza dos objetos do querer). O princípio da autonomia é, portanto: não escolher senão de modo a que as máximas da escolha estejam incluídas simultaneamente, no querer mesmo, como lei universal" (KANT, 2011, p. 90). 


\section{$\varphi \quad$ Filosofia, Engajamento e Sociedade}

moralidade. "Não há nenhum autêntico princípio da moralidade que, independente de toda experiência, não tenha que se fundar na razão [...]" (KANT, 2008, p. 45). Na religião, Kant mostra que a moral, enquanto fundada no conceito de homem como um ser livre, não precisa nem da ideia de outro ser acima do homem para conhecer o seu dever, nem de outro móbil que seja diferente da lei moral para observar. Por isso, explica que "[...] a moral [...] basta a si própria em virtude da razão prática” (KANT, 2008, p. 11). Dessa forma, fica evidente que para que a vontade seja autônoma, ela jamais deve provir de uma fonte externa e estranha ao próprio sujeito, mas tão somente da própria razão. Isso tem como implicação fundamental a premissa de que moralidade fundamentada na própria razão prática e tão somente nela exclui a possibilidade de que algo externo seja o seu fundamento.

Por isso, a razão prática, então, é prática na medida em que é capaz de determinar que sua vontade seja independente de toda e qualquer inclinação. Isso rejeita toda tentativa heterônoma de fundamentar a moralidade na tradição, na vontade de Deus, na revelação de Deus e na própria religião, pois nem Deus, nem a revelação e nem a religião podem ser o fundamento da lei moral. Isso deixa evidente que nenhum princípio empírico pode se constituir como fundamento da moralidade, porque a fundamentação de princípios morais baseados em princípios heterônimos não podem valer como lei universal.

Assim, a ideia de Deus, por exemplo, serve para garantir, como veremos mais à frente, que o sumo bem seja possível. Ela possui, como característica peculiar, a propriedade de gerar influência na vontade fortalecendo os móbiles morais no cumprimento do dever, não como 
fundamento da lei moral, mas apenas como consequência dela.

No entanto, Kant é enfático em afirmar que, apesar de a moral não se fundamentar na religião, conduz a ela 35. Indo mais além, ele mostra que a moral não só conduz inevitavelmente à religião, mas também aponta para um fim moralmente obrigatório, que está ligado com a posse de uma vontade que se determinou pela lei moral.

[...] embora a moral não precise, em prol de si própria, de nenhuma representação de fim que tivesse de preceder a determinação da vontade, pode ser que mesmo assim tenha uma referência necessária a um tal fim, a saber, não como fundamento, mas como às necessárias consequências das máximas que são adotadas em conformidade com as leis. Pois sem qualquer relação de fim não pode ter lugar no homem nenhuma determinação da vontade, já que tal

35 São várias as interpretações sobre a possibilidade de a religião ser ou não uma continuação da filosofia moral de Kant. As divergências interpretativas dos comentadores de Kant vão desde a análise do conceito de mal radical (que será analisado mais à frente) ao aspecto da religião propriamente dito. Para Pavão, "Bruch acredita que o mal radical não poderia de modo algum ser objeto de análise da tarefa crítica", e complementa: "Podemos perceber uma consonância da leitura de Bruch com a de Beckenkamp (1996). Ambos advogam que o mal radical deve ser lido dentro das preocupações de Kant com a filosofia da religião" (PAVÃO, 2007, p. 172). No entanto, discordando dessas interpretações, Pavão afirma que: "Todavia, a alegação de que o mal radical está ligado, em Kant, às questões da filosofia da religião não é suficiente para afastar a possibilidade de entender o mal radical, antes de tudo, como um conceito da filosofia moral" (Ibid., p. 173). Concomitante a isso, Pavão mostra que: "Para Loparic, a religião é um momento de inflexão do desenvolvimento da filosofia prática em Kant" (PAVÃO, 2010, p. 111). Adoto, neste trabalho, a perspectiva de que a religião em Kant é fundamentalmente oriunda de sua filosofia moral. 
determinação não pode dar-se sem nenhum efeito, cuja representação tem de se poder admitir, se não como fundamento de determinação do arbítrio e como fim prévio no propósito, decerto como consequência da determinação do arbítrio pela lei em ordem a um fim (KANT, 2008, p. 12).

Nota-se que, para a determinação da vontade, se faz necessário a relação com um fim. Mas, esse fim, necessário da razão, não pode se constituir como fundamento dela, pois, se assim fosse, ocorreria uma heteronomia da vontade. Por isso, Kant atrela a ideia de um fim da razão ao conceito de vontade. Isso é de suma importância, pois para que uma vontade seja boa importa, antes de tudo, o seu fim e não o meio. Dessa forma, o que determina a vontade como princípio objetivo é especificamente o seu fim dado pela razão, para, assim, se constituir válido para todo ser racional.

Na Fundamentação da Metafísica dos Costumes Kant afirma que "[...] a vontade é concebida como a faculdade de se determinar a si mesmo a agir em conformidade com a representação de certas leis" (KANT, 2011, p. 64). Isso mostra que o valor moral de uma ação não consiste em seus resultados, mas, antes, em sua fundamentação na lei moral, que é possível graças à potencialidade do ser humano, enquanto ser racional, de determinar sua ação de acordo com a razão, apoiando-se exclusivamente na lei. O fim, que resulta dessa ação apoiada na lei e que determina objetivamente a vontade, tem de ser válido igualmente para todos os seres racionais. O contrário disso, ou seja, o que contém apenas o princípio da possibilidade da ação cujo efeito é um fim, chama-se meio. Dessa forma, fica evidente que o fim proposto pela razão é uma consequência da vontade que se determinou pela lei moral. 
Isso é necessário porque sem a ideia de um fim moral, o arbítrio, sob essa determinação, saberia como agir, mas não saberia a direção desse agir. Por isso, mesmo não sendo necessário à moral fim algum bastando-lhe apenas a lei que contém a condição formal do uso da liberdade, dela, da moral, promana um fim, porque não pode ser indiferente à razão a pergunta: “o que resultará desse reto agir?" (KANT, 2008, p. 13). O fim que resulta dessa ação será necessariamente bom e, na medida em que contém todos os fins objetivos, terá de ser o sumo bem.

Mas Kant (2008) deixa claro que a ideia de um fim é apenas uma ideia de um objeto que contém em si a condição formal de todos os fins, o sumo bem, que passa a ser uma direção para o arbítrio que se conformou com a lei moral. $\mathrm{E}$, para que não se caia em uma heteronomia, ele mostra que o ponto principal é que "[...] tal ideia deriva da moral não como seu fundamento" (KANT, 2008, p. 14). Ou seja, é um fim cuja autoproposta já pressupõe fins morais, que possui como prerrogativa dar uma direção para o agir. Isso supre a necessidade natural do homem de sempre precisar pensar um fim para suas ações, pois não pode ser indiferente à moral que ela forme para si o conceito de um fim último de todas as coisas, na medida em que só assim se pode proporcionar realidade objetiva prática à combinação da finalidade da natureza, felicidade, como a finalidade da liberdade, o dever.

Isso se deve porque, para Kant, “[...] há no homem a necessidade moralmente operada de pensar ainda em relação com seus deveres um fim último como resultado do seu agir moral" (KANT, 2008, p. 14). Mas para se chegar ao fim último moralmente obrigatório, é necessário entender que fim é sempre o objeto de uma inclinação, de um apetite imediato para a posse de alguma coisa por meio da ação. 


\section{$\varphi \quad$ Filosofia, Engajamento e Sociedade}

Um fim objetivo é aquele que é dado pela simples razão e o fim que contém a condição iniludível e, ao mesmo tempo, suficiente de todos os outros é o fim último. Kant explica que "[...] a felicidade própria é o fim último subjetivo de seres racionais no mundo". É um fim que cada um tem em virtude de sua natureza dependente de objetos sensíveis, a qual seria absurdo dizer, segundo Kant (2008, p. 14), “[...] que se deve ter como dever". Kant explica ainda que todas as proposições práticas que possuem esse fim como fundamento são sintéticas, mas ao tempo empíricas. Por isso, não podem se constituir como um fim moralmente obrigatório. Já, o fim moralmente obrigatório, que é “[...] fazer para si do supremo bem possível no mundo o fim último" (KANT, 2008, p. 15), é uma proposição práticaobjetiva dada pala razão pura. Ela é sintética a priori, porque vai além do conceito de deveres no mundo, acrescentando um efeito que não está contido nas leis morais, não podendo, por isso, se desenvolver analiticamente delas.

Deve ficar claro, no entanto, que essa propriedade de ter de possuir um fim, uma direção para o agir, é uma propriedade de seres racionais finitos. Uma vontade livre dos impulsos sensíveis já possuiria a concordância de sua vontade com a lei, não precisando, por isso, de nenhuma determinação para o seu agir. Segundo Herrero, para Kant, "[...] é uma limitação da natureza humana [...] o fato de o homem ter de estabelecer fins para sua ação, apesar de ter seu fundamento suficiente da determinação na lei moral" (HERRERO, 1991, p. 38). Isso se dá pelo fato de o homem não ser, apenas, um ser do mundo inteligível, mas também do mundo sensível sujeito às leis da natureza. Como um ser inteligível, dotado de razão, o homem é um fim em si mesmo e deve buscar esse fim na sua própria razão e não 
em fomentos exteriores seja de qualquer tipo for, mas como um ser sensível ele precisa de uma direção para o seu agir, pois não ser indiferente à indagação sobre qual seria o resultado do seu correto agir.

Kant chama de fim, "[...] o objeto de um conceito, na medida em que este for considerado como a causa daquele (o fundamento real da sua possibilidade)" (KANT, 2012, p. 57). Isso significa que no conceito de finalidade existe uma relação causal entre a representação do resultado de uma ação e o próprio resultado, ficando pressuposto, então, que de nossa ação moral surge um efeito e que o efeito dessa ação é exatamente a direção desse agir. Segundo Herrero: "Se o arbítrio humano não pode satisfazer-se em sua ação sem saber para onde ela se dirige, essa necessidade humana não se saciará [...]" (HERRERO, 1991, p. 41).

Como para Kant, "[...] a ideia de um fim como consequência da determinação do arbítrio pela moral é um dever" (KANT, 2008, p. 13), porque sem ideia de um fim o arbítrio saberia o que fazer, mas não saberia para onde ir, na medida em que, como dito acima, não se poderia ser indiferente à pergunta sobre o que lhe seria permitido esperar do seu correto agir, o que concorda com essa ideia passa a ser também um dever. Ou seja, se tem de ser possível a realização do fim último, tem de ser possível também o que torna possível esse fim último. Isso significa que, se é possível a felicidade adequada com a observância do dever, um sumo bem no mundo, devemos supor que também que seja possível um ser superior, moral, santíssimo e onipotente capaz de unir esses dois elementos. Por isso, a ideia de Deus, considerada praticamente, não se torna vazia, porque alivia ou satisfaz a nossa necessidade natural de pensar um fim último justificado pela razão. E a falta desse fim, por consequência, resultaria em um 


\section{$\varphi \quad$ Filosofia, Engajamento e Sociedade}

obstáculo para a nossa decisão moral. Dessa forma, “[...] a moral conduz, pois, inevitavelmente à religião, pela qual se estende, fora do homem, a ideia de um legislador moral poderoso, em cuja vontade é fim último (da criação do mundo) o que ao mesmo tempo pode e deve ser o fim último" (KANT, 2008, p. 14). Isso explica mais claramente por que a proposição "[...] faz do sumo bem possível no mundo o teu é fim último é uma proposição sintética $a$ priori” (KANT, 2008, p. 15). Ela é introduzida pela lei moral e leva a razão prática a se estender além dela mesma, mas isso só é possível em virtude de a lei se referir à propriedade natural do homem de ter pensar para todas as ações, além da própria lei, ainda um fim.

Por fim, se se deve pensar como causa da produção do sumo bem como fim a mais estrita observância das leis morais e a capacidade humana não consegue tornar efetiva no mundo a felicidade em consonância com a dignidade de ser feliz, então há que se aceitar um ser moral onipotente como soberano do mundo, sob cuja providência isso acontece. Por isso, então, a moral conduz inevitavelmente à religião.

\section{$O$ conceito de sumo bem}

Luchi (2012, p. 58), entende que "[...] o conceito de sumo bem pode ser considerado como fio condutor da filosofia da religião de Kant e como precursor heurístico de outros conceitos como mundo moral, Reino dos Céus, Comunidade ética e Reino dos fins". Isso se justifica porque a lei moral, pelo conceito de sumo bem como objeto da razão prática, leva necessariamente à religião, na medida em que o dever de promover o sumo bem resulta única e exclusivamente da lei moral. Luchi (2012, p. 58) explica ainda "[...] que o duplo componente do sumo bem, 
moralidade e felicidade, estão no mesmo nível e representam duas totalidades distintas”. A felicidade é sempre condicionada, a moralidade, por sua vez, além de ser incondicionada, é a mais alta condição da felicidade com base moral. É o supremo bem que não é ainda o sumo bem, união de virtude e felicidade. Isso se dá porque a virtude, caracterizada por Kant como "[...] a disposição moral em luta [virtude]" (KANT, 2015, p. 297), é o que torna o homem digno de felicidade. E a felicidade caracterizada como a "[...] satisfação de todas as nossas inclinações (tanto extensive, quanto à sua multiplicidade, como intensive, quanto ao grau e também protensive, quanto à duração)" (KANT, 2013, p. 640), é consequência do agir moral e não uma condição necessária dele. Por ser consequência do agir moral, Herrero (1991, p. 42) entende que "[...] homem encontra na ideia do sumo bem possível no mundo um móvel mais para a ação". No entanto, surge a questão: como entender um motivo a mais para a ação se a lei moral exclui qualquer outro motivo como seu fundamento? Herrero (1991) explica que, como a ação moral tem de ser realizada no mundo, a lei nos impõe o dever de tornar o mundo adequado aos fins morais. Por isso, o ideal do sumo bem não se caracteriza como um móvel sensível que possa colocar em risco a moralidade. Isso porque ele é introduzido pela lei visando fins morais, não se deduzindo analiticamente dela.

A lei moral, sendo formal e limitando-se à legislação universal, prescreve absolutamente seja qual for o resultado da ação, e o fim acrescenta um efeito que não está contido nela, mas que é moral, porque é desinteressado. Assim, apesar de todo fim ser sempre um objeto da inclinação, o fim término da vontade pode ser um móvel porque toda a sua força vem da lei moral (HERRERO, 1991, p. 42). 


\section{$\varphi \quad$ Filosofia, Engajamento e Sociedade}

Na Crítica da Razão Prática, Kant (2015) mostra que no conceito de sumo bem, que é prático porque é realizável pela vontade, virtude e felicidade são pensadas como necessariamente vinculadas, de modo que uma não pode ser admitida pela razão prática pura sem que a outra também lhe pertença. Essa vinculação é sintética porque vai mais além do conceito de deveres no mundo, acrescentando um efeito que não está contido nas leis morais. Essa sinteticidade como conexão da causa com o efeito diz respeito a um bem prático. Ou seja, a um bem que é possível mediante uma ação. Nessa relação, ou o apetite de felicidade tem que ser a causa motriz de máximas da virtude ou a máxima da virtude tem de ser a causa eficiente da felicidade. Segundo Kant:

O primeiro caso é absolutamente impossível, porque [...] máximas que põem o fundamento determinante da vontade na aspiração à sua felicidade não são de modo algum morais e não podem fundar nenhuma virtude. Mas o segundo caso também é impossível, porque toda a conexão prática das causas e dos afetos no mundo, como resultado da determinação da vontade, não se guia segundo disposições morais, mas segundo a faculdade física de usá-las para seus propósitos. Consequentemente não pode ser esperada nenhuma conexão necessária e suficiente do sumo bem, da felicidade com a virtude no mundo através da mais estrita observância das leis morais (KANT, 2015, p. 403).

A promoção do sumo bem, então, é um objeto aprioristicamente necessário de nossa vontade e interconecta-se inseparavelmente com a lei moral, na medida em que a impossibilidade do primeiro caso tem que provar também falsidade do segundo. Disso segue-se a 
premissa fundamental de que se o sumo bem for impossível segundo regras práticas, a lei moral, que ordena sua promoção, seria falsa, pois iria se fundar sobre fins fictícios vazios. Por isso, Deus torna-se um postulado ${ }^{36}$ necessário em vista da realidade objetiva da lei moral. Na falta desse postulado, o homem se veria na carência de um indispensável móbil moral para suas ações. Isso porque a ideia de Deus, enquanto movente moral do dever é, por assim dizer, dentro do contexto da religião, a própria lei moral pensada como personificada. Por isso, então, o sumo bem é o objeto da razão prática não no sentido fenomênico, mas no sentido de um fim moral para a razão37. É uma ideia motriz para que homem possa ter referência para o seu agir moral, podendo crer que, se ele cumpre a lei moral, terá a felicidade como consequência.

Vale destacar que para a fundamentação da moralidade não é preciso um fim que preceda a determinação da vontade. No entanto, a vontade possui uma referência necessária a um fim, "não como fundamento, mas como as necessárias consequências das máximas que são adotadas em conformidade com as leis". (KANT, 2008, p. 12). Assim, o sumo bem se constitui como um ideal da razão pura no seu uso prático, no qual fica vetado o conhecimento no campo teórico. Kant não se

${ }_{36}$ Kant entende por postulado “[...] uma proposição teórica, mas indemonstrável enquanto tal, na medida em que ela é inseparavelmente inerente a uma lei prática que vale incondicionalmente a priori” (KANT, 2015, p. 435).

37 Kant (2015, p. 383) explica que a razão prática pura procura para o condicionado, ou seja, para o que depende de inclinações e carências naturais, o incondicionado. Esse incondicionado, ainda que não possa ser o fundamento determinante da vontade mesmo que tenha sido dado pela lei moral, é a totalidade do objeto da razão prática, o sumo bem. 


\section{$\varphi \quad$ Filosofia, Engajamento e Sociedade}

contenta com a limitação do uso da razão pura apenas em seu âmbito teórico e reivindica, por isso, o uso da razão também no âmbito prático, encontrando nele os seus fins supremos. Por esse motivo, introduz o conceito de sumo bem para mostrar que a vontade direciona-se sempre a um fim, a um interesse contínuo de realização. Dessa forma, esse ideal garante sentido às ações morais, pois sem um fim determinado para as ações, ainda que elas sejam motivadas apenas pelo dever, o que se teria seriam apenas meras abstrações. Por isso, Kant afirma que: “[...] da moral promana um fim; pois não pode ser indiferente à razão de que modo poderá ocorrer a resposta à questão que me resultará deste nosso reto agir" (KANT, 2008, p. 13). O sumo bem não é determinado por conceitos para aumento do conhecimento teórico, "é objeto total da razão prática pura, a qual necessariamente tem de representá-lo como possível, porque é um mandamento dela contribuir com todo o possível para a sua realização" (KANT, 2015, p. 42). Como o devemos ter o sumo bem como dever, necessariamente o que concorda com ele deve ser absolutamente possível. Sobre isso, Ferraz afirma que, “[...] uma vez que o sumo bem é necessário (como fim derradeiro ao qual conduzem as ações por dever e conforme a ele), tudo aquilo que é necessário à sua realização também o é" (FERRAZ, 2005, p. 121). Dessa forma, o postulado de Deus como um ser superior, moral, santíssimo, capaz de unir os dois elementos do sumo bem e que não é determinado objetivamente, torna-se necessário para o homem atingir os fins supremos da razão. Por isso, para Kant, então, “[...] a moral conduz, pois, inevitavelmente à religião, pela qual, se estende fora do homem, à ideia de um legislador moral poderoso, em cuja vontade é fim último [...]" (KANT, 2008, p. 14). 
Diante de um fim proposto pela razão, o agente racional fica obrigado a se direcionar a tal fim. Ele não pode abandonar racionalmente esse fim e nem persegui-lo sem acreditar na sua possível obtenção pelas atitudes que toma em sua direção. Consequentemente a isso, o agente racional tem boas razões, independente de qualquer evidência teórica, para sustentar a crença de que o fim moral é passível de ser atingido e para sustentar, também, qualquer outra crença que esteja vinculada a esse fim. Por isso, Kant diz que "[...] a ideia de um soberano moral do mundo é uma tarefa para a nossa razão prática. Não se trata de saber o que é Deus em si mesmo (a sua natureza), mas o que é como ser moral” (KANT, 2008, p. 145).

Dessa forma, chega-se ao conceito de religião racional. Essa religião racional é a lei moral como mandamento divino. Diz Kant, “[...] a única religião verdadeira contém só leis, isto é, princípios práticos de cuja necessidade nos podemos tornar conscientes e que, portanto, reconhecemos como revelados pela razão pura (não empiricamente)" (KANT, 2008, p. 169). Isso significa que o homem compreende a lei moral como mandamento divino porque a consequência da lei moral deve ser a realização do sumo bem. É somente assumindo que Deus é o único ser capaz de estabelecer o sumo bem no mundo que se pode dizer que a lei moral é um mandamento divino. Isso porque a ideia de Deus é estabelecida como aquela que é capaz de realizar o que a razão já antes determinou. Como a lei moral é único fundamento determinante da vontade, Kant explica que por mais que o sumo bem seja o objeto total da razão prática pura, ou seja, de uma vontade pura, ele não pode ser tomado como fundamento. A lei moral, diz Kant, “[...] unicamente tem que ser considerada o fundamento para tomar para si como objeto aquele sumo 


\section{$\varphi \quad$ Filosofia, Engajamento e Sociedade}

bem e a sua realização ou promoção" (KANT, 2015, p. 387). Isso significa que é somente quando a lei moral é tomada como fundamento que se tem o dever da realização do sumo bem, estabelecendo, dessa forma, por meio da ideia de Deus, o que a razão já antes determinou.

\section{A ideia de Deus e sua relação com a religião racional}

A ligação sintética entre felicidade e moralidade somente é possível se a felicidade for determinada pelo agir moral. Isso significa que a subordinação necessária da felicidade à moralidade somente é possível por meio da ligação com um valor em si mesmo. E esse valor único em si mesmo, capaz de executar tal ligação, tem de ser o incondicionado da razão prática, a saber, Deus. Assim, pelo fato de o postulado da existência Deus estar em íntima relação com a realidade da lei moral, Nodari (2009, p. 352) diz que "[...] o ser humano, de acordo com Kant, vê-se constrangido a crer em Deus, que não é, por conseguinte, objeto de um conhecimento teórico, mas de uma esperança fundada filosoficamente". Isso significa que a ideia de Deus não é senão objeto de uma crença moral, pois a lei moral ordena um fim que só pode ser atingido caso se admita a existência ou, pelo menos, a ideia da existência de Deus. Dessa forma, Deus é resultado da representação do fim último da razão pura prática, o sumo bem, que serve como meio de incentivo para o agir moral. Essa ideia serve de um móbil prático a mais, determinado pela razão, para a ação moral, não como fundamento, pois a lei moral é suficiente para isso, mas como consequência.

Esta ideia (considerada praticamente) não é vazia, porque alimenta a nossa natural necessidade de pensar um fim último qualquer que possa ser 
justificado pela razão para todo o nosso fazer e deixar de fazer tomado no seu todo, necessidade que seria, aliás, um obstáculo para a decisão moral (KANT, 2008, p. 13).

Nota-se que, para Kant, a ideia de Deus não é vazia, porque sem essa coerência interna a nossa potência moral seria cada vez mais enfraquecida. Sem a possibilidade da adequação das nossas ações à lei moral como ideia de orientação da razão como um bem que pode ser alcançado, não seria suprida a nossa necessidade natural de pensar um fim último para as nossas ações. O que precisa ficar claro, no entanto, é que a lei moral não precisa de nenhum fim para mostrar o dever que precisamos cumprir. Porém, dela promana um fim que deriva da moral, não como seu fundamento, mas como uma proposta que já pressupõe princípios morais. Por isso, a ideia de Deus se refere a um conceito puro da razão, no qual não se pode encontrar nenhum referente seu na experiência, em que correria o risco de se tornar uma ficção, um mero saber heurístico da razão. Assim, se julgarmos essa ideia do ponto de vista teórico, ou seja, como referenciais teóricos, ela se tornará uma ficção da razão sem valor de conhecimento nenhum.

Nunca posso, portanto, nem sequer para o uso prático necessário da minha razão, admitir Deus, Liberdade e Imortalidade, sem ao menos recusar à razão especulativa a sua pretensão injusta a intuições transcendentes [...]. [Por isso, diz Kant], [...] Tive pois de suprimir o saber para encontrar lugar para a crença (KANT, 2015, p. 27).

Nota-se que é negado à razão especulativa o progresso no campo suprassensível, mas resta ainda, no campo prático, a possibilidade de se encontrar fundamento 


\section{$\varphi$ Filosofia, Engajamento e Sociedade}

racional para o que no campo especulativo não foi possível conseguir. Por isso, a Crítica da Razão Pura termina por impor obrigatoriamente a busca de outro caminho, para assegurar racionalmente o uso da razão prática que a ética tradicional fundava na metafísica dogmática. Isso requereu que Kant suprimisse o saber para dar lugar a fé. Lima Vaz (2015, p. 330), sobre essa questão, explica que a expressão "tive pois de suprimir o saber para encontrar lugar para a crença" é igual "[...] a suprimir toda forma de dogmatismo e a assegurar um fundamento racional sólido à fé, entendida aqui como a necessidade inerente à razão como razão prática de admitir a realidade da liberdade, da alma imortal e de Deus".

Isso significa que Kant queria outra ideia de conhecimento além de uma ideia de conhecimento teórico que poderia se referir meramente à ação no mundo real. Ele queria um conhecimento prático e não apenas um conhecimento teórico objetivo do mundo. Assim, essas ideias, liberdade, imortalidade da alma e Deus, que não nos dizem nada de concreto no âmbito teórico, dado que não podem ser provadas, dizem muito, no âmbito prático, sobre a relação da vontade com a lei moral. Mas isso mostra que o conhecimento prático tem uma fragilidade natural, na medida em que tem que se acreditar na coerência da razão, pois a ideia, uma vez que se refere a um conceito puro da razão, não possui nenhum referente na experiência. Por isso que, para Wood (2009, p. 214), Kant, na sua famosa frase, quando declara que se deveria restringir o saber para dar lugar à fé, " [....] sustenta que, embora a razão teórica não nos possa fornecer o conhecimento de Deus nem provas da sua existência, considerações práticas podem justificar uma crença, nem que seja para os fins da ação moral, de que há uma sábia, benevolente e justa providência que ordena o 
mundo". Isso significa que assumir a ideia de Deus é colocar uma fé moral na ideia de um objeto que contém em si a condição formal de todos os fins, uma vez que, como agente moral guiado pela razão, o homem forma a concepção de um fim único que unifica o objeto de seus esforços com aqueles de outros seres bem intencionados. Por esse motivo, a ideia de Deus como resultado da representação do objeto da razão pura prática ou como o interesse da razão pura prática não pode ser tomada objetivamente, como se Deus pudesse ser conhecido teoricamente, mas apenas praticamente 38 . Wood (2009, p. 216) explica, que, dessa forma, não nos fica comprometida "[...] a real existência de Deus, mas somente a possibilidade de que haja um Deus". Isso significa que o mínimo da teologia que é requerido pela religião e pela conduta moral. Não é uma fé assertórica, mas apenas uma crença de que Deus possivelmente existe. Contudo, explica ainda Wood (2009, p. 216) que "[...] é igualmente evidente que Kant pensa que concordar com a existência real de Deus é mais adequado para uma disposição moral convenientemente entendida do que é esse mínimo". Isso mostra que Kant queria pensar seu argumento moral da existência de Deus como propiciando uma base racional para a atitude sincera e moralmente engajada. Isso permite mostrar que a relação de ideia de Deus com a religião se dá no fato de que obedecer a Deus é obedecer à lei moral e obedecer à lei

${ }^{38}$ Luchi (2012, p. 62) explica que “[...] para o homem esse interesse não é imediatamente prático porque o homem é finito e não tem nem intelecção e nem poder para realiza-lo, o que somente é faculdade de uma vontade divina onipotente”. É por esse motivo, então, que está permitido ao homem somente crer racionalmente na ação de um Deus absolutamente bom, onipotente e onisciente. 


\section{$\varphi \quad$ Filosofia, Engajamento e Sociedade}

moral é obedecer à própria razão, o que se constitui como base fundamental da religião racional.

Loparic (2009, p. 255) entende que a resposta à questão da existência real de Deus não faz parte dos problemas centrais da doutrina da religião de Kant. Diz ele, "[...] trata-se de uma doutrina da religião sem Deus, mas não sem a ideia de Deus". A ideia de Deus é uma ideia construída pela razão humana com a finalidade de fortalecer os motivos morais. Isso mostra a importância do fenômeno religioso no pensamento de Kant, na medida em que, por meio da ideia de Deus presente no conceito de religião, a ação pode encontrar incentivos para o seu agir moral. Por isso, Loparic (2009, p. 257) entende que "[...] as transformações posteriores dos postulados da existência de Deus [...] em regras práticas do como se, [servem, segundo ele] para modular conceitualmente o agir humano". A ideia de Deus não traz nenhum ensinamento objetivo relativo à realidade de seu objeto, mas possui um ensinamento subjetivo e praticamente válido em termos de agir como se soubéssemos que esse objeto é efetivo e possivelmente válido. Assim, se tem a máxima "aja como se Deus existisse".

Mas em atenção ao objeto em vista do qual nossa razão, que ordena moralmente, nos ensina a agir, pressupõem-se uma fé prática que promete um efeito para o propósito final desta razão, por conseguinte, uma fé assertórica livre - suposição de que apenas necessita de ideia de Deus, na qual deve inevitavelmente desembocar todo o trabalho moral sério [...] (KANT, 2008, p. 156, grifo nosso).

É por isso, que já é subjetivamente suficiente para estabelecer como dever a todo o homem o mínimo de 
conhecimento, qual seja, que é possível que Deus exista e que o modo agradá-lo é agindo moralmente. O sentido de seu postulado e de sua relação com a religião não é prova sistemática de sua existência real, mas mostra sua relevância no sentido de infundir influência sobre a vontade humana para que a lei moral possa determiná-la suficientemente.

Por isso, para Kant, a religião pode tornar-se um perigo, porque tem a ver com as ações humanas e, as ações humanas, se não forem orientadas de forma sadia dentro do contexto religioso, tendem a cair no mais absoluto fanatismo, esquecendo-se totalmente de que o fundamental na religião é o elemento moral39. "A ilusão religiosa fanática é a morte da razão, e sem esta não pode em geral haver religião alguma" (KANT, 2008, p. 177). Dessa forma, a religião institucional só tem valor enquanto referida à religião pura da razão.

Dentro da religião institucional convivem dois princípios hierarquicamente opostos, quais sejam, os princípios necessários por causa da fraqueza da natureza humana, que são os estatutos e normas restritos ao tempo e espaço no qual essa religião foi estabelecida, e os princípios universais que são válidos enquanto instrumentos de uma visão mais ampla. Esses últimos servem como andadeiras fundamentais para que as ideias morais possam ser trazidas novamente à reflexão das pessoas. Mas para isso, segundo Kant (2008, p. 177) é

39 Kant (2008, p. 127) entende que a “[...] disposição moral em nós é a base, [Anlage] [...] a intérprete de toda a religião". Isso significa que, no pensamento de Kant, a disposição moral precisa estar liberta de todos os fundamentos empíricos de determinação e de todos os estatutos que se apoiam na história, para que, assim, reine a pura religião racional, na qual "Deus seja tudo em todos". 


\section{$\varphi$ Filosofia, Engajamento e Sociedade}

preciso partir do princípio de que "[...] uma fé eclesial, que remedeia ou previne toda a ilusão religiosa além das proposições estatutárias de que por agora não pode de todo prescindir, deve conter em si um princípio para suscitar a religião da boa conduta como a meta genuína, a fim de um dia poder prescindir daquelas proposições". Isso quer dizer que um dos problemas centrais da religião em Kant é saber se as pessoas podem se tornar moralmente boas a partir de si mesmas, não sendo necessário recorrer, para isso, a regras doutrinais e proposições estatutárias, das quais a religião da razão deve prescindir.

Assim, para que a religião esteja de acordo com a razão pura, uma mudança para melhor não pode ser produzida por elementos externos e nem pela ajuda divina. Dessa forma, Kant deixa claro que a religião da razão pertence a uma ordem puramente moral, na qual o homem deve primeiro saber qual é o seu dever antes de acatá-lo como mandamento divino. A essa consciência de que o homem deve primeiro saber qual é o seu dever e que é "uma consciência que é para si própria dever”, sendo, portanto, a "faculdade de julgar moral que a si mesmo se juga", Kant chamou de "consciência moral" (KANT, 2008, p. 187).

\section{SEGUNDA PARTE}

\section{O Mal radical}

Na primeira parte vimos que, para Kant, a religião torna-se o resultado de exigências morais e não apenas o resultado da adoção e da observância de estatutos e credos. Ela tem como premissa fundamental saber se uma pessoa pode se tornar moralmente boa a partir de si mesma. No entanto, como pode o homem se tornar moralmente bom se 
existe em sua natureza uma propensão para o mal? Dessa forma, a questão do mal radical torna-se relevante para as questões morais, uma vez que o valor moral está estreitamente vinculado ao modo como o homem o articula em termos de hierarquia. Assim, um dos problemas fundamentais da religião é descobrir se o homem é moralmente bom ou moralmente mau, para, então, explorar e oferecer possibilidades que possam extirpar os obstáculos que se impõem à conduta moralmente boa.

\section{A propensão para o mal na natureza humana}

Kant entende por propensão "[...] o fundamento subjetivo da possibilidade de uma inclinação (desejo habitual, concupiscentia)", na medida em que é contingente para a humanidade em geral (KANT, 2008, p. 34). Trata-se de uma inclinação para o mal moral que se estabelece quando há uma deflexão no fundamento subjetivo das máximas, que pode ser chamada de inclinação natural do homem para o mal. Para Kant, essa propensão pode ser concebida como pertencente à natureza humana, mas de forma contingente porque não pertence ao conceito de homem, ou seja, não é constitutiva do homem. O que é constitutivo do homem é sua disposição (Anlage) para o bem, como veremos mais à frente.

São três os graus da propensão para o mal na natureza humana: fragilidade, impureza e malignidade ${ }^{40}$. A fragilidade mostra certa descontinuidade entre o querer e o

${ }^{40}$ Spinelli (2014, p. 232) explica que "[...] a definição de mal moral, enquanto inversão da ordem dos móbiles, está estreitamente ligada à caracterização dos graus da propensão ao mal”. Daí, então, a importância de se tratar desses graus, que vão desde sua intensidade mais baixa até a superior, constituindo-se como a gênese do que será chamado de mal radical. 


\section{$\varphi \quad$ Filosofia, Engajamento e Sociedade}

fazer. Afirma Kant: “[...] eu admito o bem (a lei) na máxima do meu arbítrio; mas o que objetivamente na ideia (in thesi) é um móbil insuperável é, subjetivamente (in hypothesi) quando a máxima deve ser seguida, o mais fraco (em comparação com a inclinação)" (KANT, 2008, p. 35). Podese ver que a fragilidade comporta o reconhecimento e o acolhimento incondicional da lei moral, mas não consegue manter esse status incondicional da lei. Spinelli (2014, p. 236) explica que "[...] no âmbito da fragilidade, o homem adota, efetivamente, a máxima de seguir a lei moral [...], mas o plano subjetivo é frágil para dar continuidade a essa incorporação". Isso significa que a fragilidade diz respeito a uma adoção relativamente fraca do homem em relação à máxima que ele adotou. A lei é admitida na máxima, mas não resiste como móbil suficiente da vontade e, dessa forma, acaba-se por se introduzir nela a inclusão de incentivos vindos das inclinações. Por isso, Kant denomina a fragilidade como "[...] a debilidade do coração humano na observância das máximas adotadas em geral”, resumida na queixa de um Apóstolo: "tenho, sem dúvida, o querer, mas falta o cumprir” (KANT, 2008, p. 35).

$\mathrm{O}$ segundo grau da propensão é a impureza. $\mathrm{Na}$ impureza não há fraqueza em aderir ao princípio moral, no entanto a máxima não é puramente moral, ela vem mesclada com outros móbiles. O homem mistura os móbiles morais e invalida, dessa forma, a pureza da lei. Afirma Kant, "[...] a impureza do coração humano consiste em que a máxima é decerto boa segundo o objeto (o seguimento intentado da lei) [...], mas não puramente moral, i.e., não acolheu em si, como deveria ser, a mera lei como móvel suficiente" (KANT, 2008, p. 36). Aqui, há a mistura do móbil moral com o imoral, o que permite a contaminação da verdadeira intenção boa, pois a vontade 
ainda precisa de outros moventes para determinar suas ações, que podem até ser conformes ao dever, mas não se tornam exclusivamente por dever.

O último grau da propensão para o mal é a malignidade ou "[...] o estado de corrupção do coração humano. É a inclinação do arbítrio para máximas que pospõem o móbil dimanante [ou seja, procedente] da lei moral a outro (não morais)" (KANT, 2008, p. 36). Os dois graus anteriores desaguam nesse último, onde o estado é mais sério. Kant também chama esse grau de "estado de corrupção do coração", porque, aqui, o homem inverte a ordem moral do móbil da vontade. Dessa forma, ainda que possam ocorrer ações legalmente boas, o modo de pensar é corrompido na sua raiz. Por isso, no que diz respeito à intenção moral, o homem se torna mal. Isso porque diferente dos graus anteriores, a máxima, segundo a qual se deve apreciar todo o valor da pessoa, é totalmente contrária à lei e o homem, embora faça ações boas é, contudo, mal. Spinelli (2014, p. 242) afirma que "[...] a malignidade representa o mal nu e declarado. Trata-se de uma subordinação do móbil moral àqueles da inclinação". A malignidade contempla todos os elementos que caracterizam a inversão da ordem dos móbiles e a subordinação dos incentivos morais aos incentivos exteriores. Por isso, Kant entende que "[...] não podemos partir de uma inocência que nos seria natural, mas temos de começar pelo pressuposto de uma malignidade do arbítrio na adoção das suas máximas contra a disposição moral [Anlage] [...]" (KANT, 2008, p. 57). Pelo fato de não se poder partir de uma inocência, o homem, na adoção de suas máximas, sempre inicia pelo mal. Ele não inicia seu estado moral a partir do principio moral que é superior, ele inverte a ordem hierárquica desses princípios e toma o 


\section{$\varphi \quad$ Filosofia, Engajamento e Sociedade}

amor de si como máxima fundamental das ações. Na Fundamentação da Metafísica dos Costumes Kant explica que

Máxima é o princípio subjetivo da ação e tem de se distinguir do princípio objetivo, quer dizer da lei prática. Aquela contém a regra prática que determina a razão em conformidade com as condições do sujeito (muitas vezes em conformidade com a sua ignorância ou as suas inclinações), e é, portanto o princípio segundo o qual o sujeito age (KANT, 2011, p. 61).

No entanto, na Religião nos Limites da Simples razão, Kant mostra um conceito novo, que ele chamou máxima fundamental. Kant se refere a essa máxima como "[...] um fundamento, universalmente presente no sujeito, de todas as máximas particulares [...] que, por seu turno, também é uma máxima" (KANT, 2008, p. 26-27). O homem, por um ato livre, subverte essa máxima e coloca como máxima das suas ações não os princípios morais, mas o amor de si ${ }^{41}$. Isso significa que o mal consiste, então, em um reviramento da prioridade, uma inversão, uma subversão das máximas da ação. Ao invés de o homem colocar como máxima das suas ações os princípios morais, ele subverte a ordem hierárquica dos móbiles e coloca como móbil da sua vontade um princípio oposto à lei.

${ }^{41}$ Segundo Heck: "Como princípio, o amor próprio toma a felicidade pessoal como determinação maior do arbítrio. Quem opta por máximas, movido pelo amor próprio enquanto princípio, pode decidirse por regras práticas que têm por único e exclusivo fim a promoção da própria felicidade" (HECK, 1999, p. 170). Assim, por ser contingente, o princípio do amor próprio não pode se constituir como lei universal, pois leva a objetivos pautados em realizações pessoais, o que, para Kant, não contribui em nada para a moralidade. 
Essa tendência que o ser humano possui de inverter as máximas morais é oriunda exatamente de sua propensão natural para o mal. Por isso, Pavão afirma que "[...] o mal radical consiste numa propensão natural que visa a corromper o fundamento subjetivo da moralidade por meio da admissão pelo arbítrio na sua máxima da influência de um móbil oposto à lei moral" (PAVÃO, 2011, p. 46). Essa propensão é oriunda da natureza finita do homem que precisa sempre de incentivos morais para o cumprimento do dever, mas que não deixa de ser um ato livre e, portanto, imputável. Dessa forma, segundo Kant, "[...] a proposição "o homem é mau", segundo o que precede, nada mais pode dizer do que: ele é consciente da lei moral e, no entanto, acolheu na sua máxima a deflexão ocasional a seu respeito" (KANT, 2008, p. 38). Essa deflexão dita por Kant significa que o homem tomou como máxima um princípio contrário à lei moral. Na Crítica da Razão Prática ele esclarece qual é esse princípio oposto.

O exato oposto do princípio da moralidade é tornar o princípio da felicidade própria fundamento determinante da vontade, para que, como mostrei acima, tem que se computar em geral tudo o que põe o fundamento determinante que deve servir de lei, em qualquer outra coisa que na forma legislativa da máxima (KANT, 2015, p. 119).

Fica claro, então, que qualquer outro princípio que não seja a lei moral é considerado como "felicidade própria" ou como comumente é chamado, "amor de si" e equivale ao oposto da moralidade. Assim, o homem se torna mal quando coloca como máxima das suas ações o amor de si e não a lei moral. Vale destacar que Kant não condena que o homem venha a agir por amor a si. O que ele condena é que o amor de si venha a se constituir como máxima das ações. 


\section{$\varphi$ Filosofia, Engajamento e Sociedade}

O homem não pode agir movido pelas suas inclinações pessoais, mas apenas pela lei moral. Isso se justifica porque o princípio da felicidade ou do amor de si jamais podem se constituir como princípio determinante da vontade, uma vez que o que determina a felicidade de uma pessoa pode ser diferente do que determina a felicidade de outra.

O mal radical, então, está ligado ao conceito de máxima fundamental, que é uma máxima a priori, que se constitui como fundamento inteligível de todas as máximas moralmente más não verificáveis apenas pela experiência. Essa máxima, como máxima que subjaz a outra máxima como fundamento, mostra que sua adoção é um ato inteligível, a priori, e tem a ver com as intenções e não meramente com a experiência. Fica evidente, dessa forma, que o mal radical, na medida em que se instala nas intenções humanas (Gesinnung), não pode ser visível apenas pela experiência, o que nos leva a entender que um homem pode mostrar ser um ser humano extremamente bom nas suas ações empíricas, mas ter suas verdadeiras intenções totalmente corrompidas. Por isso afirma Kant: "[...] o juízo de que o autor seja um homem mau não pode com segurança basear-se na experiência" (KANT, 2008, p. 26). A maldade não está no efeito das ações, mas na máxima adotada pelo sujeito moral como princípio da ação. Segundo Krassuski, "a atitude fundamental do sujeito, que escolhe a máxima má, é perversa” (KRASSUSKI, 2005, p. 158).

Dessa forma, nota-se que há na Religião nos Limites da Simples Razão uma indagação antropológica. Isso porque na Critica da Razão Prática e na Fundamentação Metafísica dos Costumes, a vontade do homem é tomada como vontade geral, na qual o princípio que é estabelecido é de uma lei que é válida para toda a vontade racional em 
geral, não importando se é uma vontade humana ou divina42. Loparic (2009, p. 266) explica que "[...] o objeto da antropologia pragmática é [...] o homem ou a natureza humana compreendida como o conjunto de condições subjetivas - faculdades, predisposições, propensões, tendências, caráter etc., favoráveis ou desfavoráveis para a execução de regras". Pode-se ver que aqui não se estuda o que a natureza quer do homem e com o homem, mas aquilo que o próprio homem quer fazer de si mesmo. Estuda-se aquilo que o ser humano faz, pode e deve fazer de si mesmo como agente livre, com o intuito de compreender as condições de efetivação da lei moral no indivíduo. É isso que Kant mostra na Antropologia de um ponto de vista pragmático. "O conhecimento fisiológico do ser humano trata de investigar o que a natureza faz do homem; o pragmático, o que ele faz de si mesmo, ou pode e deve fazer como ser que age livremente" (KANT, 2006, p. 21). Isso mostra que o âmbito antropológico, que visa estudar o que o homem faz com ele mesmo, leva em conta a experiência como uma manifestação da liberdade.

$\mathrm{Na}$ Religião Nos Limites da Simples Razão a antropologia moral consiste no estudo das condições subjetivas e objetivas da natureza humana que são tanto favoráveis como contrárias aos princípios morais. Esses elementos antropológicos dizem respeito à propensão para o mal, à disposição originária (Anlage) para o bem e à fraqueza da natureza humana. As disposições originárias para o bem (Ursprüngliche Anlage zun Guten) são

\footnotetext{
${ }^{42}$ Sobre isso, Loparic (2009, p. 261) explica que “[...] a vontade em geral é a faculdade ou capacidade de um ser racional, dentro e fora do mundo sensível, de agir causalmente segundo a representação de leis, sejam elas empíricas ou a priori”.
} 


\section{$\varphi$ Filosofia, Engajamento e Sociedade}

chamadas assim porque pertencem necessariamente à constituição do ser humano. São elas: 1) "A disposição para a animalidade do homem como ser vivo; 2) A disposição para a humanidade enquanto ser vivo e racional; 3) A disposição para a sua personalidade, como ser racional, simultaneamente, suscetível de imputação" (KANT, 2008, p. 32). Essa última, a mais relevante para o nosso estudo, será analisada a seguir.

A fraqueza da natureza humana, por sua vez, consiste em uma "[...] particular debilidade da natureza humana [...] de nunca se poder contar com essa fé pura [racional] tanto como ela merece" (KANT, 2008, p. 109) e em uma "limitação da razão humana [...] de não poder pensar valor moral algum [...] sem ao mesmo tempo tornar humanamente representável” (KANT, 2008, p. 71). No entanto, mesmo com a propensão para o mal e a fraqueza da natureza humana, a indagação antropológica, que tem a ver com a vontade humana, mostra também que, ainda que o homem tenha tomado para si, em primeiro lugar, o princípio do mal, não são extirpadas as suas predisposições originárias (Anlage) à personalidade moral.

Por isso, o que se segue agora é ver como Kant se dedica em definir o processo mediante o qual o homem pode se restabelecer moralmente.

\section{Revolução moral e reforma gradual}

A indagação antropológica tem a ver com a vontade humana e sua predisposição moralmente boa e moralmente má. Dessa forma, ainda que o homem tenha tomado para si, em primeiro lugar o princípio do mal, não são extirpadas de sua natureza as predisposições originárias à 
personalidade moral43. Isso se dá porque, ainda que haja no homem uma propensão natural para o mal, sua disposição originária para o bem não foi extinta.

Kant chamou de personalidade moral "[...] a susceptibilidade da reverência pela lei moral como de um móbil, por si mesmo suficiente, do arbítrio, [...] a ideia da humanidade considerada de modo plenamente intelectual" (KANT, 2008, p. 33). Essa susceptibilidade à lei moral é o sentimento moral, que se constitui como móbil do arbítrio que jamais é extirpada, ainda que exista no homem uma propensão para o mal. O que precisa ficar claro aqui é que, para Kant, a personalidade moral é originária (Anlage), ou seja, é constitutiva do homem, enquanto que a propensão para o mal desenvolvida nos seus três graus, é contingente porque não é inerente ao ser humano. A personalidade moral consiste em um respeito pela lei moral que é originária pelo fato de pertencer à natureza humana enquanto tal. É uma disposição originária para o bem inerente à natureza racional do ser humano.

Ferraz (2005, p. 128) explica que a personalidade moral "[...] é disposição para sermos motivados a agir de acordo com a universalidade da máxima, ou seja, de acordo com a lei moral”. Ela é a condição da própria autonomia que torna o ser humano capaz de agir pelo incentivo da lei moral como móbil, em detrimento das inclinações particulares.

Então, apesar de o homem ter tomado o princípio do amor de si como máxima fundamental das suas ações, a sua

43 Spinelli (2014, p. 231) explica que "a disposição para o bem é concebida como originária [Anlage], o que pretende denotar que a natureza humana não seria possível (ou concebível) sem ela". Isso significa, então, que elas são originárias porque definem a natureza humana tal como ela é. 


\section{$\varphi \quad$ Filosofia, Engajamento e Sociedade}

predisposição moral para o bem não foi completamente abafada. Isso significa que o homem pode ser o pior de todos os imorais, mas ainda sim terá uma consciência moral. Mas é necessário que ele substitua a máxima fundamental do mal pela máxima fundamental do bem, que é o restabelecimento da predisposição para personalidade moral. Ao fazer isso, é restabelecida a predisposição moral no seu lugar hierárquico fundamental, que é o princípio moral.

Para restabelecer sua predisposição para o bem, o ser humano precisa, no entanto, passar por uma revolução moral. Aqui a questão não é somente se tornar legalmente bom, mas moralmente bom, o que significa que o ser humano precisa ser virtuoso segundo o seu caráter inteligível, agindo por dever e não somente conforme o dever. Herrero (1991, p. 87) explica que "[...] Kant define a conversão [o renascimento] como o restabelecimento da pureza do mesmo (ou seja, do móvel perdido para o bem)”. Isso significa que a liberdade deve aceitar o primeiro fundamento moral de todas as máximas, assim como aceitou o primeiro fundamento do mal. Dessa forma, uma revolução moral pode ser entendida como uma revolução na disposição de ânimo (Gesinnung), uma transformação do coração. É um ato inteligível que visa alcançar o fundamento das máximas da vontade produzindo uma espécie de renascimento.

Mas que alguém se torne não só um homem legalmente bom, mas moralmente bom (agradável a Deus), i.e., virtuoso segundo o seu caráter inteligível (virtus noumenon), um homem que, quando conhece algo como dever, não necessita de mais nenhum outro motivo impulsor além desta representação do dever, tal não pode levar-se a cabo 
mediante reforma gradual, enquanto o fundamento das máximas permanece impuro, mas tem de produzir-se por meio de revolução na disposição de ânimo no homem (por uma transição para a máxima da santidade dela); ele só pode tornar-se um homem novo graças a uma espécie de renascimento. Como que por uma nova criação [...] e uma transformação do coração (KANT, 2008, p. 53).

É somente com o restabelecimento da máxima fundamental da moralidade como princípio fundamental das ações que o ser humano pode falar de conceitos de graça ou de religião, uma vez que, para Kant, nada pode substituir o restabelecimento da personalidade moral. "O que o homem em sentido moral é ou deve fazer chegar a ser, bom ou mal, deve ele próprio fazê-lo ou tê-lo feito" (KANT, 2008, p. 50). No entanto, ele tenta sempre postergar essa decisão que precisa ser tomada, colocando no lugar rituais religiosos, simpatias, campanhas, que servem como disfarce para aquilo que ele deve realmente fazer, que é tomar uma decisão pelo princípio moral.

Assim, para que o ser humano saia do mal é preciso uma mudança de valores, que se constitui como base para uma transformação que ocorre de dentro para fora. É a decisão de assumir para si o bem moral em suas máximas como o propósito de cumprir o dever. É uma transformação na sua máxima fundamental que leva o homem, após isso, a entrar em um processo que o retira do mal que o afetou e o coloca no caminho da bondade.

Mas como pode o homem, que por um ato de liberdade tomou como máximas das suas ações um móbil oposto à lei moral, tornar-se bom? "A lei diz: sede santos 
(na vossa conduta de vida), como santo é vosso Pai que está no céu! [...] Mas a distância entre o bem que em nós devemos efetuar, e o mal, de que partimos, é infinita [...]" (KANT, 2008, p. 72).

O homem jamais terá sua vontade totalmente adequada à lei, porque há uma distância infinita entre o bem, que ele dever praticar, e o mal do qual ele parte. Mas isso deve ser possível e é de responsabilidade do homem fazê-lo, pois somente deve esperar ajuda divina depois de, por um ato de liberdade, tomar lei a moral como princípio do seu agir44. Somente após passar por uma revolução da consciência, ou seja, por uma reforma no seu modo de ver

44 Sobre isso, Herrero (1991, p. 87) afirma que poderia se colocar a seguinte questão contra Kant: "Como pode o homem decidir-se pelo seu passado?”. Mas ele explica que o problema não é esse, pois o ato de liberdade se situa no âmbito numênico onde não se pode falar de passado e futuro. Herrero, por isso, mostra que Kant foi chamado de incoerente por admitir uma sucessão de atos no âmbito numênico, quais sejam, primeiro a aceitação do mal e depois a do bem. Essa sucessão de atos, por mais atemporal que fosse, implicaria, contudo, numa mudança de atitude e, portanto, numa sucessão entre o antes e $o$ depois no tempo. Herrero mostra ainda que Bruch, adotando essa hipótese, afirma a impossibilidade de explicar o ato de conversão, porque é um ato de liberdade e quando a liberdade está em jogo não existe conhecimento teórico nem dela nem de seus atos. Por isso, então, a conversão é incompreensível. Opto pela visão de Herrero que explica que a resposta de Bruch é exata, mas em certo sentido é insuficiente. Isso porque o problema da possibilidade da conversão não se limita à dificuldade da sucessão e, portanto, ao tempo. "A questão da possibilidade de conversão está na possibilidade do próprio ato [...] que é dada no dever que se impõe incondicionalmente mesmo no coração pervertido" (Ibidem, p. 88). Assim, a possibilidade da conversão se dá pelo espaço aberto entre a relação da liberdade com a lei e o ato livre que escolhe o mal. 
o mundo, saindo do mal e indo em direção ao bem do qual se afastou, ele se torna digno da assistência divina.

Segundo Kant: "[...] o homem acolhe deste modo na sua máxima tal pureza, embora não seja por isso ele próprio santo (pois entre a máxima e o ato há ainda um grande hiato)" (KANT, 2008, p. 52). Pelo fato de o homem jamais conseguir conformar totalmente suas ações à lei moral, fica um abismo entre a tomada da lei como máxima e as ações como consequência e, por isso, ele sempre precisará de algo para suprir essa deficiência. Por esse motivo, então, o princípio moral tem de ser gradualmente fortalecido, pois, mesmo que seja restabelecido o princípio moral, essa fraqueza nata terá de ser fortalecida cada vez mais por uma força moralmente boa. Então, Kant pensa que, devido ao fato de "entre a máxima e o ato haver um grande hiato", o homem, ainda que em função de sua predisposição que exige como dever que o princípio moral seja restabelecido, tome por um ato de liberdade a lei moral como máxima, a fundamentação das suas ações como consequências da tomada do principio moral como máxima jamais estarão totalmente adequadas ao princípio moral. Por esse motivo, precisa estar sempre em uma reforma gradual, que, segundo Kant, "[...] terá, pois de buscar ao longo de toda a sua vida [...]" (KANT, 2008, p. 83), pois, ainda que seja resultado da revolução da consciência, ela é ad infinitum. A virtude se adquire pouco a pouco, por meio de reformas graduais do comportamento e por meio da consolidação das máximas morais. É Por isso que para Kant, é um processo que o homem deve buscar durante toda a sua vida.

Kant mostra que a relação entre revolução moral e reforma gradual se dá seguinte forma: "para o modo de pensamento, é necessário a revolução e, por isso deve também ao homem ser possível, mas para o modo do 


\section{$\varphi \quad$ Filosofia, Engajamento e Sociedade}

sentido (que opõe obstáculo àquela) requer-se a reforma gradual" ( KANT, 2008, p. 53). Kant atrela revolução moral ao pensamento e reforma gradual ao sentido para mostrar que essa relação se dá respectivamente no âmbito do inteligível e do sensível. Quando o homem toma a lei moral como horizonte de determinação das suas ações, ele faz isso no âmbito inteligível. Somente assim é possível uma revolução moral que restabelece a ordem hierárquica dos móveis da vontade, uma vez que, como explica Herrero ( 1991, p. 82) "[...] a origem do mal é [...] impenetrável”. Só podemos dizer que sua origem é racional e está no próprio homem, no âmbito inteligível.

Kant entende, também, que a relação entre revolução moral, que se dá no âmbito inteligível e se refere ao pensamento, e reforma gradual, que se dá no âmbito sensível e refere às ações, pode ser diferenciada respectivamente quanto à qualidade e quanto ao grau. "Quanto à qualidade (já que esta se deve pensar como suprassensivelmente fundada), deve e pode ser ela [a intenção moral] ser santa [...]". "Segundo o grau (como se manifesta nas ações) continua a ser sempre deficiente e infinitamente distante da primeira" (KANT, 2008, p. 81). Isso significa que a máxima fundamental do homem deve ser a lei moral do ponto de vista do mundo inteligível, tornando possível a mudança de coração que ocupa o lugar do todo. No entanto, em um mundo que supõe obstáculos, essa transformação se realizará por meio de uma reforma gradual (segundo o grau), que é resultado da revolução da consciência (segundo à qualidade) e que se estende ao infinito por causa da deficiência da natureza humana que é propensa ao mal. Por isso, diz Kant: "Não obstante, esta intenção [Gesinnung], por conter o fundamento do progresso contínuo no complemento desta deficiência, 
ocupa, como unidade intelectual do todo, o lugar do ato na sua consumação" (KANT, 2008, p. 81).

Pode-se ver que Kant desiste, na "Religião nos Limites das Simples Razão", da reconciliação entre ideias e práticas e as ações como consequências dessas ideias. No entanto, ele desenvolve uma teoria das intenções. Ele compreende a intenção assumindo o lugar do todo, na medida em que a qualidade traz intelectualmente a unidade do todo entre consciência e ações como consequência da consciência. Por isso, a revolução permite que o homem, segundo a qualidade, seja julgado como bom, ainda que não seja bom absolutamente, pois, mesmo que os princípios morais sejam restabelecidos, as ações como consequência dos princípios morais nunca serão adequadas, na maior parte do tempo, a esses princípios morais restabelecidos. Portanto, segundo a qualidade o homem se torna agradável a Deus, mas segundo o grau, ele não é e, verdade, nunca será absolutamente moral.

Embora fisicamente (considerado segundo o seu caráter empírico como ser sensível) seja o mesmo homem punível, e como tal deve ser julgado perante um tribunal moral, por conseguinte, também por ele próprio, contudo, na sua nova disposição de ânimo [Gesinnung] (como ser inteligível) perante um juiz divino, diante do qual tal disposição represente o ato, é moralmente outro, e esta na sua pureza $[\ldots]$ satisfaz mediante padecimentos e morte a justiça suprema como redentor e, enquanto advogado, faz que os homens possam aparecer como justificados diante do seu juiz (KANT, 2008, p. 81 , grifo meu).

Pode-se ver que é a intenção, essa nova disposição de ânimo (Gesinnung) que faz com que os homens possam 


\section{$\varphi \quad$ Filosofia, Engajamento e Sociedade}

aparecer como justificados perante o seu juiz. A intenção é o comando dessa lei. É a unidade intelectual da lei moral como marca fundamental que cumpre papel do todo. É como se ações humanas fossem necessariamente conformes ao comando da lei moral, porque no interior do homem há uma unidade do todo quando a lei moral é tomada como máxima fundamental das ações. É como se as ações humanas como consequência disso, pelo menos do ponto de vista intelectual, resultassem estar de acordo com a lei. É o que Kant chamou da "dedução da ideia de uma justificação do homem” (KANT, 2008, p. 82). Isso significa que a adequação absoluta das ações como consequência da qualidade moral é uma ideia que não pode ser observada pela experiência, mas que é necessária para que a razão pura prática possa dar contar da inadequação entre lei e ações como consequência da lei45.

Então, poderíamos dizer que máxima kantiana do "o que devo eu posso" só pode ser entendida somente segundo a qualidade, pois segundo o grau isso jamais será possível. O que se tem, então, é uma unidade intelectual, a intenção, que cumpre o papel do todo no ato das ações.

45 Ideia é um conceito que ultrapassa a possibilidade da experiência. Na Crítica da Razão Prática Kant afirma que "[...] as ideias transcendentais não são nunca de uso constitutivo, que por si só forneça conceitos de determinados objetos e, no caso de assim serem entendidos, são apenas sofísticos dialéticos" (KANT, 2013, p. 542). Sobre isso, Nodari (2009, p. 70) "[...] ideia é um conceito que ultrapassa a possibilidade da experiência". "Os conceitos da razão contém o incondicionado e concernem a algo ao qual toda a experiência é subordinada, mas ele mesmo jamais é objeto da experiência”. Foram esses conceitos da razão que Kant denominou de ideias transcendentais. 
Nota-se, dessa forma, que o fenômeno de religião é importantíssimo para dar conta desse abismo que se abre entre o comando da lei e as ações como consequência da lei. A implicação disso é a conclusão de que o conceito de religião no pensamento de Kant, na Religião nos Limites da Simples Razão, não é adjacente. Ele visa dirimir esse conflito instalado entre o princípio que foi colocado como horizonte de orientação das ações e as ações como consequência desse comando. Afirma Kant:

Aqui, deve ele [o homem] sobretudo conhecer o seu caráter, pelo menos em certa medida; portanto, embora acredite que teve um lugar uma melhoria na sua intenção [Gesinnung], deve ao mesmo tempo trazer à sua consideração a antiga (corrompida) [intenção] de que partiu e poder examinar o que dela deitou fora e em que medida, e que qualidade (se pura ou impura) e grau tem a suposta disposição de ânimo [Gesinnung], para superar a primeira e impedir a recaída na mesma; terá, pois, de a buscar ao longo de toda a vida (KANT, 2008, p. 83).

Quando ocorre a revolução segundo qualidade, em que o homem tem a possibilidade de acreditar que houve uma melhoria na sua intenção, o seu caráter pode ser julgado como bom. Mas as ações como consequências dessa revolução que foi estabelecida, nem sempre se adéquam ao caráter moral. Segundo a qualidade, o homem é bom, mas segundo o grau o homem está distante de ser bom, porque ele não consegue realizar todos os seus deveres morais. A diferença é que agora a lei moral foi restabelecida em sua personalidade moral, ou seja, a lei moral foi restabelecida em sua supremacia hierárquica. Por isso, agora está disposto ao homem que todas as consequências desse estabelecimento sejam cada vez mais adequadas a essa revolução introduzida segundo a qualidade. Mas para 


\section{$\varphi$ Filosofia, Engajamento e Sociedade}

impedir sua recaída, o ser humano, ao longo da sua vida, deve ser cada vez mais preenchido por exercícios, práticas pedagógicas, religião, reflexão, pois, segundo Kant “[...] aqui, a consciência moral deveria antes excitar-se e afinarse para não descuidar o que ainda há de bom por fazer, ou de mau para anular" (KANT, 2008, p. 84). Depois da revolução na consciência, o homem entra num processo de desenvolvimento moral que se dá por meio da reforma gradual. Por esse motivo, a religião torna-se tão importante que o conceito que Kant estabelece é um conhecimento puro a priori que não se diferencia em nada da lei moral, pois a religião da qual Kant trata é a religião moral pura.

Por fim, é de se destacar que é somente com restabelecimento da máxima fundamental da moralidade como princípio fundamental que só pode falar de conceitos de graça, justificação, Deus etc. Esses símbolos, por exemplo, não podem ser tomado como valores em si mesmos. Isso porque a ideia de uma adequação das ações à lei moral tem de ser suficientemente clara à razão de todo o ser humano e os símbolos servem apenas para torná-la intuitiva. Se assim não fosse, esses símbolos gerariam a mais pura ilusão que, para Kant, "[...] é o engano que consiste em ter a simples representação de uma coisa por equivalente à própria coisa" (KANT, 2008, p. 170). Os símbolos por si mesmos não possuem qualidade moral. Isso significa que a forma correta de proceder com eles é por ascendência. É ir aos símbolos para retornar à razão, pois os valores dos símbolos precisam se referir às ideias racionais. 


\section{$O$ arquétipo do bom princípio}

Para a luta vitoriosa do bem sobre o mal, Kant mostra que o ser humano precisa de um exemplo concreto, um modelo que possa trazer a representação do nível do esforço que é tomado pela máxima fundamental das ações, para que, assim, apesar das barreiras, se cumpra o dever. Na Crítica da Razão Pura, Kant já retratava a representação de Cristo como a ideia da humanidade agradável a Deus.

A humanidade, em toda a sua perfeição, não contém apenas extensão de todas as propriedades essenciais que pertencem à natureza humana [...], o que seria a nossa ideia da humanidade perfeita, mas também tudo o que além deste conceito pertence à determinação completa dessa ideia; pois que, de todos os predicados opostos, só um poderá ser adequado à ideia de homem sumamente perfeito (KANT, 2013, p. 486).

Nota-se que a ideia da perfeição moral é uma ideia da razão. Isso significa que o arquétipo da moralidade deve ser procurado na razão prática. Dessa forma, a figura de Cristo serve apenas como estímulo em busca da adequação entre as ações a lei moral. Por isso, Kant não concentra sua atenção no Jesus histórico. O que importa é a ideia que Cristo representa e a suscetibilidade que essa ideia encontra na natureza humana, de forma que o ser humano não pode querer esgotar na própria representação de Cristo o seu significado. Isso teria como consequência a falta da exata compreensão do que de fato essa representação tem a dizer sobre os conceitos práticos da razão. Isso porque é da própria razão que surge o ideal da humanidade em sua completa perfeição moral, uma vez que a moralidade não permite a necessidade de um exemplo tomado da experiência. O ideal da humanidade perfeita, então, é 


\section{$\varphi \quad$ Filosofia, Engajamento e Sociedade}

apenas um protótipo. O ideal já está no homem. Ele é apenas representado ao homem como resultado da ação do exemplo de outro homem completamente correto em sua conduta moral.

Assim como a ideia dá a regra, assim o ideal, nesse caso, serve de protótipo para determinação completa da cópia e não temos outra medida das nossas ações que não seja o comportamento deste homem divino em nós, com o qual nos comparamos, nos julgamos e assim nos aperfeiçoamos, embora nunca o possamos alcançar (KANT, 2013, p. 468).

Nota-se que não é intenção de Kant negar a divindade de Cristo. Kant pretende apenas mostrar que a hipótese de sua origem divina não oferece qualquer vantagem do ponto de vista prático. Pelo contrário, o valor prático de seu exemplo está exatamente em não se revestir de qualquer caráter sobrenatural. No entanto, é bastante dificultoso ao homem elevar-se a esse ideal de humanidade perfeita, isso porque ele jamais conseguirá conformar totalmente sua conduta à santidade da lei. Por isso, é necessário ao homem se contentar em situar sua moralidade na intenção (Gesinnung), na vontade de conformar sua conduta à lei. E a ideia de uma humanidade agradável a Deus ajuda na deficiência das ações humanas, na medida em que essa deficiência pode ser melhorada pela pureza das intenções em se conformar à ideia de um homem agradável a Deus. É por esse motivo que na Religião Nos Limites da Simples Razão Kant afirma que "Na fé prática deste filho de Deus [...] pode o homem esperar tornar-se agradável a Deus (e deste modo bem aventurado)" (KANT, 2008, p. 68).

$\mathrm{O}$ que Kant quer mostrar com a representação de Cristo é que o ser humano pode desenvolver uma 
disposição moralmente boa, tomando esse arquétipo como exemplo. É por isso que, para Kant, como já dito, não importa o Jesus histórico, mas apenas a ideia que ele representa, de forma que transformar a validade dessa ideia apenas na encarnação seria decair da fé e perder de vista o motivo pelo qual encarnou, que é mostrar a intenção moralmente boa. O seu intuito é representar a pureza moral que o ser humano deve alcançar por meio do arquétipo da vitória do princípio bom, representado aqui pela figura do filho de Deus.

Ora o ideal da humanidade agradável a Deus [...] não o podemos pensar de outro modo a não ser sob a ideia de um homem que estaria pronto não só a cumprir ele próprio todo o dever do homem e a difundir ao mesmo tempo à sua volta, pela doutrina e pelo exemplo, o bem maior possível, mas também, embora tentado pelas maiores atrações, a tomar sobre si todos os sofrimentos, até a morte mais ignominiosa, pelo bem do mundo e, inclusive, pelos seus inimigos (KANT, 2008, p. 67).

Kant quer mostrar que a figura de Cristo potencializa no ser humano a consciência de suas capacidades morais, na medida em que remete à ideia de um homem que experimentou em sua natureza humana todos os tipos de tentações e em nenhum momento se desviou de sua conduta moralmente boa. Por isso, o arquétipo do bom princípio "[...] é a humanidade na sua plena perfeição moral [...], é consequência imediata da vontade do Ser supremo" (KANT, 2008, p. 66). Ser a humanidade na sua perfeição moral significa, então, que Cristo foi tentado e, mesmo podendo ter pecado, permaneceu fiel. Ele travou uma luta e sofreu ao ponto de dar a vida pelos outros. Por isso, serve com um ideal prático muito importante para o ser humano, 


\section{$\varphi \quad$ Filosofia, Engajamento e Sociedade}

na medida em que transmite a ideia de que Ele morreu cumprindo o dever. "Esse homem agradável a Deus resistiu às tentações” (KANT, 2008, p. 87). Isso mostra que se Cristo fosse apenas um ser puro, santo, mas que não fosse tentado e não tivesse sua conduta moral colocada à prova, não poderia ser um exemplo eficiente e suficiente da disposição moral em luta.

Kant (2008, p. 66) entende "[...] este homem, o único agradável a Deus, está Nele desde a eternidade; a sua ideia respectiva promana do seu ser; não é por isso, uma coisa criada, mas o seu filho unigénito". Cristo, sendo filho de Deus e estando em Deus desde eternamente, ao se encarnar, rebaixou-se a um estado de humilhação, porque antes de vir a esta terra como homem já era agradável em e para si mesmo com Deus e em Deus. Isso significa que antes de se tornar homem Cristo já era a lei moral, já era puramente inteligível e agradável a Deus em sua perfeição moral, porque já vivia na ideia divina desde toda a eternidade.

Kant tenta mostrar com isso, que a representação de Cristo significa uma tentativa da religião cristã de explicar o fenômeno da lei moral que vigora na razão do ser humano desde toda a eternidade. O ser humano é lançado no mundo sob a vigência dessa lei e o ideal de Cristo, que é a priori, na medida em que reside na razão humana, possui a finalidade de tornar compreensível ao homem a ideia moral do bem tornado pessoa. Esse arquétipo "[...] não é para alargar o nosso conhecimento além do mundo sensível, mas apenas [...] para tornar intuível, para uso prático, o conceito do que para nós é insondável [...]" (KANT, 2008, p. 65-66). É a ideia racional da humanidade perfeita em si mesma que, apesar de não ser vista na experiência, porque é apenas uma ideia da razão, precisa ser humanamente representável, 
tornando intuíveis para o homem os princípios morais que precisa seguir para vencer sua luta contra o mal. Isso se dá porque o ser humano não pode "[...] pensar valor moral algum [...] sem ao mesmo tempo tornar [...] humanamente representável” esse valor (KANT, 2008, p. 71).

Conclui-se, assim, que o ideal do bom princípio, como um conceito racional, é fundamental porque serve de móbil para que o homem possa sair do mal e ir em direção ao bem do qual se afastou. "A fé viva no arquétipo da humanidade agradável a Deus (no Filho de Deus) encontra-se em si mesma referida a uma ideia moral da razão, na medida em que esta não serve não só de regra, mas também de móbil" (KANT, 2008, p. 124).

\section{O esquematismo por analogia}

Kant vai tentar ver como os protótipos ou as representações religiosas podem ajudar a tornar compreensíveis as ideias práticas. Ele fará isso mostrando como a religião, por meio dos seus símbolos, pode auxiliar o ser humano nessa empreitada.

Para isso, Kant mostra que as ideias precisam ser compreendidas por vias sensíveis, intuíveis. Isso porque a natureza humana possui uma "necessidade natural" de sempre precisar de um "apelo sensível" para entender os conceitos abstratos da razão (KANT, 2008, p. 115). Capitani (2008, p. 4-5) mostra a importância da questão da sensificação dos conceitos morais em Kant, uma vez que, do contrário, esses conceitos não passariam de meras abstrações de um formalismo vazio. Segundo ele, "[...] é necessário esclarecer que o estudo da religião é realizado diante da problemática semântica da sensificação da lei moral na natureza humana". Isso significa que o grande problema é encontrar uma conexão entre a lei e a 


\section{$\varphi \quad$ Filosofia, Engajamento e Sociedade}

sensibilidade. Tem de ser possível sensificar a lei moral na natureza humana, pois, do contrário, ela não teria significado, referência, não passaria "[...] de uma quimera, de um formalismo vazio, como afirmam os críticos de Kant" (CAPITANI, 2008, p. 5).

Dessa forma, A religião nos Limites da Simples Razão, nessa perspectiva, pode ser analisada como uma tentativa de tornar visível essa relação da religião com a natureza humana, isto é, de sensificar a lei moral. "[...] O invisível precisa de ser representado no homem por algo visível (sensível) e, inclusive, o que ainda é mais, ser por este acompanhado em vista do prático e, embora seja intelectual, torna-se por assim dizer intuível (segundo certa analogia)" (KANT, 2008, p. 194).

O ser humano, por causa da limitação de sua natureza, precisa sempre desse elemento sensível para poder conseguir compreender, mesmo que de forma limitada, aquilo que é o comando do dever. O homem não age sem esse elemento ou pelo menos não compreende isso que é o comando do dever, a menos que recorra ao apelo de um elemento sensível. Por esse motivo, na religião, Kant formula o esquematismo por analogia, que difere do esquematismo por determinação do objeto.

Höffe (2005. p. 111), explica que o esquematismo por determinação do objeto "[...] trata da relação de um material indeterminado com sua forma determinante". Nesse esquematismo, que também pode ser chamado de esquematismo transcendental, os conceitos do entendimento só encontram validade objetiva no elemento sensível. Isso significa que eles só poderão possuir valor objetivo se forem interpretados sensivelmente. "Os esquemas dos conceitos puros do entendimento são, pois, 
as condições verdadeiras e únicas que conferem a esses conceitos uma relação a objetos" (KANT, 2013, p. 186).

Mas as diversas formas de síntese do múltiplo da intuição só se mostram como determinações objetivas se houver um elemento que seja homogêneo tanto ao conceito como ao dado intuído. Segundo Kant "[...] essa representação mediadora deve ser pura (sem nada de empírico) e, todavia, por um lado, intelectual e, por outro, sensível. Tal é o esquematismo transcendental!" (KANT, 2013, p. 182). Então, cabe a capacidade transcendental da imaginação produzir os esquemas que tornam possível a aplicação das categorias aos dados da intuição. Höffe (2005, p. 85-86) explica que "[...] sem as categorias não é possível um conhecimento objetivo". No entanto, as categorias, como formas puras do entendimento, precisam das impressões dos sentidos que se presentam no espaço e no tempo, que são as formas puras da intuição. As categorias, então, possuem a função de síntese, sem as quais os dados diversos da intuição sensível não poderiam ser conhecidos. "São as condições que subjazem originalmente no sujeito, sem as quais não é possível a unidade conceitual de uma intuição dada" (HÖFFE, 2005, p. 86). Nesse esquema, os conceitos se esgotam naquilo que é intuído. Eles só fazem sentido nesse intuito e no intuído mesmo se esgotam.

No entanto, as ideias racionais não podem ser submetidas a esse esquema, pois a dialética revelou exatamente $o$ fracasso de se querer avançar rumo ao suprassensível como se ele fosse uma realidade abstraída de conceitos. Segundo Höffe (2005, p. 41), “[...] todas as tentativas da filosofia tradicional de obter conhecimento na esfera da metafísica especulativa estão, em princípio, condenadas ao fracasso". Então, o objetivo da dialética, 


\section{$\varphi \quad$ Filosofia, Engajamento e Sociedade}

como lógica da ilusão, é mostrar que a tentativa da razão pura de conhecer algo além dos fenômenos, no sentido de ser esse algo verdadeiro, tende a falhar inevitavelmente 46 .

Nos Prolegômenos, Kant mostra que a proibição de atribuir a Deus, por exemplo, propriedades pertencentes a objetos da experiência evita o antropomorfismo dogmático. Mas mostra, também, que um antropomorfismo simbólico é permitido, porque "[...] concerne à nossa linguagem e não ao próprio objeto" (KANT, 2014, p. 140). Essa analogia, como se mostra já nos Prolegômenos, "[...] não significa, como se entende comumente a palavra, uma similaridade imperfeita de duas coisas, mas antes uma perfeita similaridade de duas relações entre coisas inteiramente dissimilares" (KANT, 2014, p. 141). Assim, a simbolização é um recurso para conceitos do suprassensível que não pode ser apresentado ou esgotado em si mesmo, pois remete necessariamente a um conhecimento prático por analogia.

Na Crítica da Faculdade do Juízo, Kant explica que "[...] todas as intuições que submetemos a conceitos $a$ priori são esquemas ou símbolos, dos quais os primeiros contêm apresentações diretas, e os segundo apresentações indiretas do conceito. Os primeiros fazem isso demonstrativamente e os segundos mediante uma analogia [...]" (KANT, 2012, p. 215). Kant quer mostrar, com isso, a diferença daquilo que é mostrado apenas por esquemas de forma demonstrativa, onde um elemento sensível que a razão instrumentaliza esgota o seu significado nele mesmo,

46 Meirelles (2009, p. 279) explica que “[...] ainda que as ideias não possuam realidade objetiva teórica, entretanto, em função do interesse prático, elas deixam de ser meros conceitos vazios e, portanto, adquirem sentido, passando a corresponder, de certo modo, a objetos". 
daquilo que é simbólico e é mostrado por meio de analogia. $\mathrm{Na}$ analogia, os elementos sensíveis são símbolos, que no contexto da religião se tornam símbolos de ideias práticas. Essas ideias não esgotam os seus significados em si mesmos porque não são referentes objetivos desses símbolos.

Por isso, nas representações religiosas, por exemplo, quando se pensa na figura de Cristo e esgota a ideia prática que está por trás dessa representação no próprio fenômeno representativo, o que se tem é apenas uma exterioridade. Não se pode esgotar isso que é inteligível e que faz parte do campo prático moral no elemento sensível. Aqui, é de se destacar que, para Kant, a representação de Cristo precisa ser ascendente, precisa ser uma representação por analogia. O ideal do bom princípio não pode representar nenhum conhecimento objetivo sobre a representação de Cristo. Isso porque é um ideal por analogia e não um "esquematismo por determinação do objeto", em que há a aplicação de conceitos sobre os objetos para aumento do conhecimento.

No entanto, na religião, apesar desse novo horizonte relativo às ideias práticas no âmbito dos conceitos teóricos das categorias da Crítica da Razão Pura, não se poderia entender essas ideias práticas se não houvesse o elemento sensível. Essa é a grande questão para Kant. Por isso ele afirma que "[...] é sem dúvida, uma limitação da natureza humana, que nem sequer dela se há de separar, o fato de não podermos pensar valor moral algum de importância nas ações de uma pessoa sem, ao mesmo, tornar humanamente representável esta pessoa ou a sua manifestação" [...] (KANT, 2008, p. 71, grifo meu).

Kant entende que o ser humano possui uma fraqueza que lhe é natural. Por esse motivo, ele precisa sempre de um 


\section{$\varphi \quad$ Filosofia, Engajamento e Sociedade}

elemento sensível para poder compreender conceitos racionais. Mas isso não significa substituir os conceitos pelos símbolos, significa proceder por ascendência. Isto é, ir ao símbolo para retornar à razão. O símbolo em si mesmo não tem qualidade moral, mas se refere às ideias racionais. Isso significa que no conhecimento prático moral os símbolos não possuem significados neles mesmos, ao menos que sejam remetidos a uma ideia.

Assim, no esquematismo por determinação do objeto, o que se tem é um conhecimento objetivo, no qual os conceitos e categorias interagem com os fenômenos numa relação de sujeito e objeto. No conhecimento prático moral, no entanto, essa representação sensível, que não teria sentido nela mesma ao menos que fosse remetida a uma ideia, só é acessível por ascendência. Por isso, então, Kant desenvolve o esquematismo por analogia na Religião nos Limites da Simples Razão.

Tal é o esquematismo por analogia (para explicação), de que não podemos prescindir. Mas transformá-lo num esquematismo da determinação do objeto (para a ampliação do nosso conhecimento) é antropomorfismo, que num proposto moral (na religião) tem as mais prejudiciais consequências (KANT, 2008, p. 215).

Como para Kant o ser humano não consegue entender uma ideia pura sem um referente, porque precisa sempre de um esquema para entender conceitos, o esquematismo por analogia servirá para poder mostrar, didaticamente, a ideia que o símbolo transmite. Deve-se ir ao símbolo, compreender a ideia e voltar para a ideia. Com isso, Kant mostra que os símbolos religiosos precisam remeter às ideias morais, pois, do contrário, corre-se o risco de antropomorfizar as representações religiosas, transferindo 
sua representação à coisa mesma e deixando de compreendê-la com um mero símbolo que deveria ser remetido ao seu lugar mais fundamental. "O antropomorfismo [...] é sumamente perigoso quanto à nossa relação prática com a vontade de Deus e para nossa moralidade" (KANT, 2008, p. 170). Aqui o perigo é tomar aquilo que é um simples meio como se fora um fim para algo. Por isso, é preciso entender que o símbolo é uma projeção da imaginação humana, que se for tomado como fim em si mesmo gerará o antropomorfismo. Kant quer evitar, assim, que se tome uma representação sensível, que é contingente e sujeita ao tempo e lugar, no lugar de um conceito racional, que vale para todos e não apenas para uma determinada época. O objetivo de Kant com isso é mostrar que as religiões possuem a tendência negativa de produzir ilusão religiosa e fanatismo. A ilusão religiosa “[...] é o engano que consiste em ter a simples representação de uma coisa por equivalente à própria coisa" (KANT, 2008, p. 170

\section{TERCEIRA PARTE \\ O sumo bem comunitário}

Vimos que o homem, por meio de uma revolução de sua consciência, pôde dar o primeiro passo para sair do mal, mas apenas o esforço individual não é totalmente suficiente para que isso se concretize. Por isso, o dever de um progresso moral tem que ser de todos. Isso exige "[...] uma união de pessoas num todo em vista do mesmo fim, [...] como república universal segundo leis de virtude" (KANT, 2008, p. 104). Nota-se que com a ideia de comunidade ética, Kant mostra como a sociedade possui influência determinante na vida das pessoas. Por esse motivo, então, os seres humanos precisam estar engajados no 


\section{$\varphi$ Filosofia, Engajamento e Sociedade}

estabelecimento do reino de Deus na terra. Kant pensa num ambiente onde as pessoas sejam cada vez mais introduzidas eticamente na moral, a ponto de toda a humanidade poder ser determinada moralmente. Esse é um dever não de homens para com homens, mas do gênero humano como um todo para consigo mesmo.

Kant desenvolve essa problemática começando pela constatação de um estado de natureza ético que culmina na necessidade de uma comunidade ética que, por sua vez, é consumada pela ideia do sumo bem comunitário. Spinelli (2012, p. 38) explica que "[...] a argumentação da comunidade ética decorre do pressuposto de que é a maneira como as relações entre os homens se estabelecem que gera o mal moral". Spinelli se refere aqui ao estado de natureza ético, que Kant denomina como "[...] um estado de incessante assédio pelo mal, que se encontra no homem e, ao mesmo tempo, em todos os outros" (KANT, 2008, p. 103). Kant extrai esse conceito de natureza ético do conceito clássico de estado de natureza, que ele chamou aqui na religião, de estado de natureza jurídico. "Assim como o estado de natureza jurídico é um estado de guerra de todos contra todos, assim também o estado natureza ético é um estado de incessante assédio pelo mal" (KANT, 2008, p. 103).

No estado de natureza, que Kant toma emprestado de Hobbes, os homens supõem que podem todas as coisas e, para tanto, utilizam-se de todos os meios para atingi-las. Eles são maus por natureza e só se impõem ao outro pela força. O que move o homem é a submissão dos outros aos seus próprios critérios para a realização dos seus próprios 
desejos47. É um estado em que cada qual quer ser juiz sobre o que é seu direito frente ao que é de direito dos outros e não tem, por parte dos outros, nenhuma segurança de que seus direitos serão respeitados. "É um estado de guerra em que todos devem constantemente estar armados contra todos" (KANT, 2008, p. 103). Nesse estado de natureza, o homem fica incapacitado de realizar seus próprios desejos. Ele não tem segurança nenhuma, porque em todo tempo ele é assediado pelo mesmo desejo de posse que possui. Então, a paz não é possível, já que se tem de permanecer em estado de guerra constante contra o outro. Por isso, os homens precisam se reunir para criar um Estado onde todos, incluídos num pacto, possam ter seus direitos garantidos.

Kant entende que um estado civil de direito (político) é a relação dos homens entre si, enquanto estão comunitariamente sob leis de direito públicas (que são no seu todo leis de coação) (KANT, 2008, p. 101). Com isso, pretende-se inibir o conflito estabelecido na tentativa de apaziguar a guerra de todos contra todos. O homem, por medo, se juntaria a outros homens não por solidariedade, mas para construir um Estado que garantiria a coesão social, que, no caso de Hobbes, seria o Estado soberano. É sobre essa problemática que Kant se debruça para explicar o conceito de estado de natureza ético. Sobre isso, Spinelli explica que

47 Segundo Kant “A proposição de Hobbes: status hominum naturalis est bellum omnium in omnes não tem nenhum outro defeito a não ser o de que deveria dizer: est status belli" (KANT, 2008, p. 103). Ou seja, um estado no qual ocorre uma lesão contínua dos direitos de todos, por meio da pretensão do homem em ser juiz nos seus próprios afazeres submetendo os outros ao seu próprio arbítrio. 
O estado de natureza ético é um estado de natureza não pela ausência de leis (pois a lei moral se impõe espontaneamente no íntimo de todo o humano), mas porque não há observância ou consideração incondicional à influência dessa lei, tal estado de natureza é ético porque diz respeito a uma condição de barbárie do ponto de vista moral, o qual está presente na vida social civil e carece de uma conscientização interna que não pode ser proporcionada por leis coercitivas (Spinelli, 2012, p. 38).

Pode-se ver que estar num estado de natureza ético é viver numa sociedade na qual o princípio moral não foi atingido como máxima para a orientação das ações. Ainda que se tenha entrado no estado civil e que se tenha saído do estado de natureza, essa natureza ainda não sabe que seu verdadeiro estado de natureza ético deveria ser um estado de natureza recíproco com as leis da virtude. Não basta apenas que o homem seja inserido num estado político. É preciso também o seu estado de natureza ético não esteja infectado. Para Hobbes, o homem sem as leis estabelecidas no direito positivo não poderia ter a noção de bem e mal. Mas, para Kant, independente do Estado, o homem tem a noção de uma lei natural moral. O homem não seria uma tábula vazia que só conhece o bem ou mal mediante um estado jurídico. Ele conhece seu dever independente do estado em que ele se encontra.

No entanto "[...] no estado de natureza ético, os agentes adotam máximas nas quais a primordial preocupação é satisfação de seus interesses, e para tanto, não há qualquer receio no sentido de servir-se dos outros agentes para alcançar seus objetivos" (Spinelli, 2012, p. 39). É de se notar que essa condição fere ferozmente a fórmula 
kantiana da humanidade exposta na Fundamentação ${ }^{48}$. O agente não se considera como um fim em si mesmo, na medida em que se deixa dominar pelas inclinações. Por isso, na relação com os outros, esse agente, receoso de ser usado como meio para fins alheios, se antecipa e usa os outros agentes para os seus próprios fins. É por isso que, para Kant, o estado de natureza ético esse é "[...] público assédio recíproco dos princípios de virtude e um estado de interna amoralidade, de que o homem se deve, logo que possível, aprontar a sair" (KANT, 2008, p. 103).

Por esse motivo, Kant desenvolve o conceito de comunidade ética, em que o que se espera é que seja gerada uma confiança recíproca entre os agentes no cumprimento da lei moral. Não se trata, apenas, de um cada fazer sua parte, mas sim de cada um progredir moralmente, podendo acreditar e confiar que o outro fará o mesmo. Foi a essa união de pessoas, com o mesmo fim sob leis de virtude, que Kant chamou de comunidade ética.

\section{Comunidade ética}

Ainda que o homem tenha um arquétipo para a sua conduta moralmente boa e passe por uma revolução moral tomando a lei moral como máximas das suas ações, ele precisa estar engajado em uma sociedade que contribua para a sua evolução moral. Para Kant, "O império do princípio bom, na medida em que os homens para ele podem contribuir, só é alcançável [...] mediante a ereção e a extensão de uma sociedade segundo leis de virtude [...]" (KANT, 2008, p. 100).

48 "Age de tal maneira que uses a humanidade, tanto tua pessoa como na pessoa de qualquer outro, sempre e simultaneamente com fim e nunca simplesmente como meio" (KANT, 2011, p. 73). 


\section{$\varphi \quad$ Filosofia, Engajamento e Sociedade}

Kant entende como "dever para todo o gênero humano" (KANT, 2008, p. 110) o estabelecimento de uma comunidade ética universal, na qual não seriam as leis do Estado que garantiriam a harmonia da sociedade, mas as leis de virtude garantidas por um legislador moral superior. "Se houver de se realizar uma comunidade ética, então todos os particulares se devem submeter a uma legislação pública, e todas as leis que os ligam se devem olhar como mandamentos de um legislador comunitário" (KANT, 2008, p. 104). Essa comunidade tem por objetivo mostrar que o princípio que foi estabelecido como uma comunidade particular tem de ser referido a uma comunidade maior, que possa fortalecer os agentes morais e possa servir, inclusive, como instrumento de contraponto ao que no geral a sociedade fornece como exemplo para aqueles que estão mergulhados no princípio do mal.

Spinelli (2102, p. 41) explica que "[...] o que impõe na comunidade ética é um pacto coletivo, em que cada um se dispõe a não obstruir o progresso do seu semelhante e se delegue ao próprio agente individual o esforço de avançar moralmente". Esse pacto é um pacto recíproco fundado na ideia de que a comunidade ética é também uma sociedade, cujo término de sua extensão se torne, por meio da razão, tarefa e dever para todo gênero humano.

Isso significa que os agentes morais se reúnem para formar um acordo que os tire do seu estado de natureza ético, em que o principio moral não é superior, mas sim o princípio da maldade. Assim, para assegurar o predomínio do bom princípio, é indispensável que homens bons se unam numa sociedade ideal constituída segundo leis de virtude que visam à moralidade dos atos.

$\mathrm{O}$ pressuposto para se engajarem nessa comunidade ética, então, é que as pessoas deixem seu estado moral 
depravado e engajem juntamente como todos em uma comunidade ética universal, em que o princípio moral seja estabelecido no seu lugar hierárquico fundamental. Isso é necessário porque segundo Kant, "[...] a inveja, a ânsia de domínio, a avareza e as inclinações hostis a ela associadas assaltam a sua natureza [...] e nem se quer é necessário pressupor que estes já estão mergulhados no mal e constituem como exemplos sedutores" (KANT, 2008, p. 100). Viver uma comunidade ética significa dizer que o ser humano que tomou a lei moral como máxima das suas ações não está sozinho no mundo com sua intenção moral. Ele está num ambiente que se encontra em harmonia com o seu intento interior e que ao mesmo tempo é um espelho dele mesmo.

Segundo Kant, "[...] se a comunidade deve ser uma comunidade ética, então não há de se considerar o próprio povo como legislador" (KANT, 2008, p. 104). Não é uma comunidade que dá leis de fora para dentro, mas uma comunidade onde as leis são internas. Essas leis internas visam à moralidade dos atos e não apenas a sua legalidade, não admitindo outros legisladores fora de Deus como soberano moral do mundo. Kant fundamenta o seu conceito de comunidade pensando em "[...] um povo sob mandamentos divinos, i.e., como um povo de Deus [...] de acordo com leis de virtude" (KANT, 2008, p. 105). Isso significa que na comunidade ética as leis visam fomentar a moralidade das ações segundo leis interiores que possuem uma forma e constituição que se distingue essencialmente da forma e da constituição da uma comunidade política.

Kant entende que "[...] existe, no entanto, entre ambas, consideradas em geral como duas comunidades, uma certa analogia" (KANT, 2008, p. 101). Essa analogia mostra que, embora sejam comunidades, a comunidade 


\section{$\varphi \quad$ Filosofia, Engajamento e Sociedade}

ética pode ser chamada também de estado ético, um reino de virtude cuja ideia tem na razão humana sua realidade objetiva, embora subjetivamente jamais se pudesse esperar da boa vontade que os homens decidissem trabalhar por tal fim. No estado ético, os homens são unidos por leis não coativas que são leis de virtude. Isso se diferencia do Estado civil de direito ou político, onde os homens estão sob leis externas de coação.

Na comunidade jurídica, erigida pelos homens, as leis visam garantir a realização conforme a legalidade e, para isso, servem-se de leis exteriores coercitivas que não podem servir como fundamento da moralidade. Mas a comunidade ética ou moral não pode ser confundida com uma comunidade jurídica, baseada em leis coercitivas que almejam a justiça externa. Uma comunidade ética que almeje o melhoramento moral dos homens precisa ser voluntária.

Um estado civil de direito (político) é a relação dos homens entre si, enquanto estão comunitariamente sob leis de direito públicas (que são no seu todo leis de coação). Um estado civil ético é aquele em que todos os homens estão unidos sob leis não coativas, i.e, sob simples leis de virtude (KANT, 2008, p. 101).

Podemos ver claramente, por meio do conceito de comunidade ética, que a religião oferece mais um meio para a progressão moral do homem. Para Kant, a religião possui um lugar na vida humana porque a ética não é apenas uma questão puramente privada, na qual cada um precisa cumprir o seu próprio dever sem se preocupar como o desenvolvimento moral do gênero humano. "Temos, pois, aqui um dever de índole peculiar, não dos homens para com homens, mas do gênero humano para consigo mesmo" (KANT, 2008, p. 103). Kant chamou a comunidade ética de 
"Igreja invisível", que deve seguir sempre os preceitos racionais da religião moral. "Uma comunidade ética sob a legislação moral divina é uma Igreja, que, na medida em que não é objeto algum da experiência possível, se chama a Igreja invisível” (KANT, 2008, p. 107).

Kant faz uma espécie de "evangelização". Ele pensa em um ambiente que possa servir de exemplo para que as pessoas sejam cada vez mais introduzidas nas leis éticas, a ponto de toda a humanidade poder ser determinada moralmente. Se a lei moral é verdadeira, então tem de ser possível que os homens se engajem moralmente para o estabelecimento do sumo bem comunitário no mundo. Tem de ser possível erigir uma comunidade mundial organizada desde o princípio da lei moral, o que seria a perfeição de uma comunidade ou uma comunidade absolutamente ética.

\section{O aspecto coletivo e individual do sumo bem}

Depois de analisar o conceito de comunidade ética, pretendo neste tópico analisar algumas questões sobre o aspecto individual e coletivo da ética de Kant. Isso se justifica porque o conceito de sumo bem, que possui forte significação individual nas obras anteriores de Kant, ganha na religião um aspecto coletivo, entendido como sumo bem comunitário.

Na Crítica da Razão Prática Kant afirma que

Ora, na medida em que virtude e felicidade constituem em conjunto a posse do sumo bem em uma pessoa, mas que com isso também a felicidade, distribuída exatamente em proporção com a moralidade [...] constitui o sumo bem de um mundo possível (KANT, 2015, p. 393, grifo meu). 


\section{$\varphi \quad$ Filosofia, Engajamento e Sociedade}

Pode-se ver que a noção de sumo bem detém forte significação individual. A conduta que se põe em questão é a conduta do agente subjetivo em relação à sua dignidade de ser feliz. Spinelli (2012, p. 42) explica que "[...] obviamente o direcionamento do sumo bem, enquanto bem comunitário, não pode suplantar o que Kant chamou de sumo bem em uma pessoa, pois tudo passa pelo agente individual". A diferença é que, na religião, o sumo bem se assenta sobre a visão de algo construído coletivamente e para a comunidade. "Toda a espécie de seres racionais está objetivamente determinada na ideia, a saber, ao fomento do sumo bem comunitário" (KANT, 2008, p. 103). Kant entende que todo ser humano está determinado a um fim comunitário que consiste exatamente na promoção do sumo bem comunitário. O que se nota de diferente do conceito de sumo bem na Crítica da Razão Prática, é que, na religião, há um operar coletivo em prol do sumo bem enquanto comunitário que pressupõe um sumo bem alcançado pelo indivíduo.

No entanto, Spinelli (2012, p. 43) mostra que Gerard Vilar, em seu texto El concepto de bien supremo em Kant, entende que Kant colocou em crise a própria identidade de sua ética, na medida em que "[...] abandonou uma posição para adotar outra”. Para esse comentador, Kant abandonou uma ética individualista para formular uma ética coletiva. Spinelli (2012) explica que, na concepção de Vilar, de um delineamento ontológico individualista, traduzido numa perspectiva monológica em que prevalecia a ética pessoal e a moralidade interna, Kant passa a uma ontologia de cunho totalmente social que tem como consequência uma ética comunitária. A ideia aqui é de que Kant abandona totalmente sua concepção individualista de ética em prol de 
uma ética fundamentalmente coletiva. Analisemos isso mais de perto.

Podemos dizer que um dos pontos fundamentais da ética kantiana na Fundamentação da Metafísica dos Costumes se constitui na fórmula "Age de tal maneira que uses a humanidade, tanto na tua pessoa, como na pessoa de qualquer outro, sempre e ao mesmo tempo como fim e nunca simplesmente como meio" 49 . É de se notar que o processo moral, tal como Kant descreve, apesar de se dar no âmbito individual, não exclui a participação da coletividade na figura do outro, afinal de contas, é outro, além da própria pessoa, que também não se deve tomar como meio para quaisquer fins.

Assim, tomando a fórmula acima como base, em nenhum momento se pode inferir que o progresso moral da pessoa humana de forma individual entra em contradição com a ideia do sumo bem comunitário. As duas coisas podem se conectar porque a ideia de sumo bem comunitário seria um acréscimo, um desdobramento da ideia de sumo bem já explícito até mesmo na Crítica da Razão Prática. "A realização do sumo bem no mundo é o objeto necessário de uma vontade determinável pela lei moral" (KANT, 2015, p. 433).

Para o estabelecimento do sumo bem, o agente moral precisa se tornar digno da felicidade, a fim de que a felicidade seja a consequência necessária do agir moral que o faz merecedor dela.

Por isso, na religião, Kant fala em termos de dignidade de ser feliz, de um merecimento da felicidade como consequência da virtude. "Para eles é suficiente que façam

49 Refiro-me ao imperativo categórico exposto na fórmula da humanidade. (KANT, 2011, p. 73). 


\section{$\varphi$ Filosofia, Engajamento e Sociedade}

o seu dever; mesmo que com a vida terrena tudo acabasse e nesta, porventura, jamais coincidissem felicidade e dignidade" (KANT, 2008, p. 15). Ele estabelece uma diferença entre lei moral e felicidade. A felicidade não pode ser o fundamento da moralidade, na medida em que é indeterminada e relativa, enquanto que a lei moral, por sua vez, se estabelece como uma lei universal para todos os seres racionais. Mas só quando o homem toma a lei moral como máxima fundamental de suas ações, quando é virtuoso, é que ele se torna digno de alcançar a felicidade. A felicidade é um conceito antagônico com a ideia de lei moral, na medida em que a lei moral é inteligível e pertence ao âmbito da liberdade, da racionalidade, enquanto a felicidade é uma petição humana que diz respeito a sua natureza enquanto ser empírico. "Restam, pois, então apenas dois fundamentos de determinação; um que é racional, a própria perfeição, e outro, que é empírico, a felicidade própria” (KANT, 2008, p. 12).

Assim, o sumo bem comunitário é uma conexão necessária entre dois conceitos díspares do ponto de vista lógico. Mas com a ideia de sumo bem, Kant pensa uma felicidade determinada como consequência dos princípios morais e não mais uma felicidade indeterminada sem o crivo da racionalidade. Então, essa felicidade, do ponto de vista moral, se torna adequada à lei moral, na medida em que o homem não se completaria na sua totalidade na ausência dessa felicidade.

Por isso, Herrero (1991, p. 103), falando sobre o sumo bem comunitário afirma que "[...] só na obediência a esse dever se manifesta no homem o sentido último e próprio da sua existência, só nela o homem pode alcançar a consumação da sua liberdade”. A união desses dois polos significa a humanidade inteira na perspectiva moral. "A 
intenção de Deus na criação do mundo é a humanidade em sua perfeição moral" (HERRERO, 1991, p. 103), mas só Deus realiza a união da felicidade com a moralidade.

No entanto, Ele só faz isso se o ser humano houver passado por uma conversão moral no seu estado ético. Isso significa que para Deus realizar a união da virtude com a felicidade, é preciso pressupor que a humanidade tenha passado por uma revolução na sua consciência e esteja progredindo em uma reforma gradual, a ponto de que todos aqueles que tenham sido maus por natureza desde o início tenham conjuntamente se engajado em prol do sumo bem comunitário. Então, trata-se de uma comunidade onde os agentes morais se reúnem para a realização do mundo moral e não mais apenas o eu individual.

Na obediência ao dever manifesta-se ao homem sua consumação como possível e nela ele tem certeza moral do modo de chegar, isto é, tem certeza de seu próprio poder moral e dela surge a esperança igualmente moral no complemento e, portanto no cumprimento efetivamente real do sumo bem comunitário (HERRERO, 1991, p. 103).

Nessa esperança igualmente moral, o agente moral buscará se reunir com outras pessoas que estejam também engajadas num bem coletivo, em que se poderá conviver e se desenvolver melhor moralmente, no meio de pessoas que estejam dispostas a também se desenvolver moralmente. A religião torna-se, então, nesse sentido, um espaço de solidariedade em uma sociedade individualista e egoísta.

Por isso, concordo com a visão de que a ética de Kant não é individualista, no sentido pejorativo do termo, mas individual. Jorge Filho (1999, p. 87) explica que "[...] individualista conviria às doutrinas segundo as quais a pessoa individual é com exclusividade a fonte autônoma 


\section{$\varphi \quad$ Filosofia, Engajamento e Sociedade}

dos deveres éticos e, ao mesmo tempo, o sujeito responsável de imputação". A concepção ética kantiana garante o exercício do arbítrio humano e, por outro lado, não o concebe como fechado em si mesmo, como se fosse isento de ser afetado por outros agentes morais.

Por isso, a ética de Kant realiza um movimento para superação de um conceito empírico, pelo qual o dever moral leva ao alargamento de uma perspectiva individualista, egocêntrica, para uma forma mais universal que englobe outras pessoas. O que se tem de individual é o dever que cada um possui de tomar a lei moral como máxima fundamental das ações. Mas essa perspectiva não é individualista. É uma perspectiva que trata do agir humano consigo mesmo, com o outro, com sua comunidade e com o mundo inteiro. Por isso, se tem a sensificação da lei exposta no imperativo: "Age de tal maneira que uses a humanidade, tanto na tua pessoa, como na pessoa de qualquer outro, sempre e ao mesmo tempo como fim e nunca simplesmente como meio". Então, acusar a ética de Kant de individualista é um equivoco interpretativo. Spinelli (2012, p. 45) corrobora com essa visão afirmando que "[...] a ética kantiana, sob esse pressuposto, não é uma ética individualista [...] porque há referência aos outros agentes, mas individual, na medida em que o modo como a gente se relaciona com a moralidade e edifica a sua conduta é uma atividade subjetiva".

Kant concilia o sumo bem individual com o sumo bem comunitário. Na Religião nos Limites da Simples Razão, Kant fala do sumo bem comunitário conciliando com a ideia de sumo bem exposto na Critica da Razão 
Prática, tratando as duas coisas como uma coisa sóso. Também, na Religião nos Limites da Simples Razão, logo depois de tratar do mal radical, Kant trata da revolução da consciência do homem para o bem. Depois, de um processo moral individual por meio da reforma gradual, para, logo após, tratar do sumo bem comunitário como uma continuação e não uma oposição.

Isso contraria absolutamente a posição de Vilar, que pensa que a ideia de um sumo bem comunitário, que implicaria na criação de uma república historicamente singular, esteja em total oposição com a ética de Kant desenvolvida nas obras anteriores. Essa ideia desmerece todas as formas de organização humana em Kant, pois, para o filósofo alemão, a sociabilidade humana é um recurso natural do ser humano, sendo que o cume dessa socialização se daria na constituição da comunidade ética. Sobre isso Herrero explica que "[...] o sumo bem comunitário significa a concordância plena da perfeição moral com a existência sensível, com a natureza e o mundo" (HERRERO, 1991, p. 104). É como se as sociedades se iniciassem em um estágio primeiro e fossem se desenvolvendo até um estágio mais complexo e completo, avançando de forma positiva até a realização da ideia do sumo bem comunitário.

Por fim, é de se notar que Kant entende que um estado justo seria uma comunidade ética que não poderia ser garantido num Estado concreto histórico. Isso porque o

\footnotetext{
$5^{\circ} \mathrm{Na}$ primeira parte deste texto, quanto tratei sobre os fins morais da razão, foi possível ver como Kant trata do conceito de sumo bem. No entanto, no decorrer do texto da religião, esse conceito se expande e Kant passa a tratá-lo de forma bem abrangente, não se limitando, apenas, em analisá-lo de forma individual.
} 


\section{$\varphi \quad$ Filosofia, Engajamento e Sociedade}

Estado concreto histórico serve para poder corrigir e para poder gerar coesão. Mas de uma comunidade ética, pelo contrário, o que se espera é que seja gerada mais confiança entre os agentes, porque são leis de virtude e não leis exteriores, ou seja, o pressuposto moral pressupõe que o agente seja autônomo e não determinado por leis externas.

Mas segundo Kant "[...] o homem comum entende sempre por religião a sua fé eclesial que lhe apresenta aos sentidos. [...] A fé eclesial estatutária é tudo o que se entende por tal palavra" (KANT, 2008, p. 114). A finalidade é que exista uma comunidade universal, mas o homem por causa de sua fraqueza natural entende sempre por religião uma comunidade restrita ao tempo e ao espaço. O que se espera é o estabelecimento de uma comunidade perfeita no mundo, mas o início dessa comunidade é sempre restrito ao tempo e ao espaço no qual ela é formada.

Mas ainda assim, a religião é um veículo bom, pois serve como meio condutor à religião pura. Isso significa que, para Kant, a fé eclesial serve para poder manter as pessoas determinadas ao estabelecimento do sumo bem comunitário no mundo como dever, na medida em que deve manter um princípio de aproximação contínuo à fé pura religiosa para, finalmente, poder prescindir desse meio condutor e, assim, restar somente a pura religião da razão. "Para a fé eclesial, pode conservar-se o influxo útil que tem como veículo [...]" (KANT, 2008, p. 129). Ter a fé eclesial como veículo significa dizer que não se pode findar o significado de seus símbolos neles mesmos, mas entender que esses símbolos precisam remeter a conceitos morais. Quando se findam os símbolos religiosos neles mesmos, perde-se de vista a fé eclesial como veículo. Isso leva o ser humano a ficar imerso apenas no tempo e no espaço com seus símbolos, confundindo conceitos universais com 
eventos particulares. Dessa forma, tudo fica reduzido a uma experiência religiosa particular coercitiva, na qual se deixa de explorar o que há de mais fundamental na religião, que é exatamente o elemento universal, a lei moral que não está restrita ao tempo e ao espaço.

Por fim, Kant entende que coadunar a fé eclesial coercitiva com a liberdade em matéria de uma fé se traduz como um problema. No entanto, isso se deve constituir como uma ideia da razão, "[...] cuja apresentação numa intuição a ela adequada nos é impossível, mas, que tem, como princípio regulativo prático, realidade objetiva para atuar em ordem ao fim da unidade da religião racional pura" (KANT, 2008, p. 129).

\section{QUARTA PARTE}

\section{A Igreja e o falso Culto}

Vimos que, para Kant, é dever o estabelecimento de uma comunidade ética universal, na qual não seriam as leis do estado que garantiriam a harmonia da sociedade, mas as leis de virtude garantidas por um legislador santo, que garantiria que as pessoas, por decisões autônomas, cumprissem o seu dever. Essa é ideia geral. É a ideia de uma comunidade extensiva internacional para o cumprimento do dever.

No entanto, o dado antropológico ${ }^{1}$ mostra que o homem é incapaz de erigir uma comunidade assim. "A ideia

\footnotetext{
${ }^{51}$ Mais uma vez temos o elemento antropológico usado para mostrar a fraqueza da natureza humana em compreender os conceitos morais. "A fé religiosa pura é a única que pode fundar uma Igreja universal [...], mas uma particular debilidade da natureza humana tem a culpa de nunca se poder contar com essa fé pura tanto quanto ela merece, a saber, fundar somente nela uma igreja” (KANT, 2008, p. 109).
} 


\section{$\varphi \quad$ Filosofia, Engajamento e Sociedade}

sublime, nunca plenamente alcançável, de uma comunidade ética míngua muito em mãos humanas" (KANT, 2008, p. 106). O homem é incapaz de estabelecer um reino dessa natureza por causa da condição da sua natureza sensível. A razão estabelece, mas o homem não pode realizá-lo. Então, o que o homem pode cumprir? Essa é a grande pergunta. Se o homem não pode concretizar com suas próprias forças a realização absoluta de uma comunidade ética no mundo, o que lhe é possível realizar? "Qual seria o fio condutor para constatar na história uma união de membros regidos pela verdadeira atitude moral?” (HERRERO, 1991, p. 157).

Instituir um povo de Deus é uma obra que não se pode esperar dos homens, mas somente do próprio Deus. No entanto, segundo Kant, "[...] não é permitido ao homem estar inativo quanto a esse negócio" (KANT, 2008, p. 106). $\mathrm{O}$ homem precisa fazer sua parte e não pode querer que somente a natureza divina atue, como se a cada um fosse permitido apenas perseguir o seu interesse moral privado, deixando tão somente a uma sabedoria divina superior todo o interesse do gênero humano. Assim, qualquer coisa que possa ser realizada precisa ser orientada por essa ideia.

Kant, então, vai falar de religiões morais. "O conceito de uma vontade divina determinada segundo meras leis morais puras permite-nos pensar, assim como só um Deus, também apenas uma religião que é puramente moral" (KANT, 2008, p. 110). Por exemplo: associações de grupos que tenham a finalidade de justiça social, do ponto de vista da moral e das leis de virtude, não precisam de leis coercitivas porque a lei moral vigora enquanto tal na razão. Mas quando elas se determinam, em conjunto, para estabelecer uma comunidade ética, em vista da realização de uma comunidade ética universal, precisam, em primeiro 
lugar, promulgar um estatuto para poder garantir a unidade desse grupo, já que esse grupo coexiste com uma sociedade muito mais ampla, que não se determinou necessariamente por princípios morais.

Pensemos numa religião pautada nos princípios morais, pelo menos, determinada pelos princípios morais. Kant acha que o cristianismo é uma religião nesse sentido. "Eis aqui, pois uma religião integral que pode ser proposta a todos os homens pela sua própria razão de modo apreensível e convincente e que, além disso, se tornou intuível num exemplo" (KANT, 2008, p. 164). Como o cristianismo traz a proposta de uma religião que torna intuível os conceitos morais, $o$ que se torna verdadeiramente importante, então, nessa religião, é a lei moral e não apenas as representações simbólicas que ali são mostradas. Essas representações, como vimos, precisam sempre se referir à lei moral, uma vez que, do contrário, perderiam o seu valor. Mas como os seres humanos não são capazes de estabelecer o sumo bem comunitário do mundo, eles se contentam, por causa de sua fraqueza enquanto homens, com pequenas comunidades, que só terão valor moral se referidas à religião pura da razão.

O que essa comunidade ética na verdade quer é que esse princípio que foi estabelecido como uma comunidade particular, restrita ao tempo e ao espaço, seja referido a uma comunidade maior. Assim, a Igreja visível, restrita ao tempo e espaço, tem de ser a representação da Igreja invisível, que é o reino moral de Deus. Isso porque a Igreja visível não garante absolutamente que as pessoas sejam verdadeiramente determinadas pela lei moral e estejam verdadeiramente cumprindo o dever moral. Mas, quando é entendida como representação da Igreja invisível, essa sociedade enquanto ideal, consegue fixar os conceitos que 


\section{$\varphi \quad$ Filosofia, Engajamento e Sociedade}

vigoram em toda consciência moral. Pascal (2011, p. 196) explica que "[...] essa sociedade, enquanto ideal, é a Igreja invisível; na medida, sempre imperfeita, em que chega e realizar-se, ela pode denominar-se Igreja visível”.

No entanto, dada a fragilidade da natureza humana, a pura fé religiosa não basta para a formação de uma Igreja. O ser humano não consegue entender que é preciso agir por dever e que nisso consiste a obediência a Deus. Então, a ideia do sumo bem comunitário visa sensificar esses princípios por meio da Igreja visível. Por isso, ela precisa ser a representação da Igreja invisível "[...] o que acarreta a necessidade da revelação, pois, se conhecemos a lei moral só pela razão, as leis estatuárias devem ter sido reveladas por Deus" (PASCAL, 2011, p. 197). Somente assim, dentro dessa comunidade, o ser humano consegue entender os conceitos morais.

Então, o que Kant quer com a ideia de realização do sumo bem comunitário no mundo é tornar claros os conceitos puros da razão. O que ele quer dizer é: a ideia de uma comunidade ética vigora enquanto tal, mas o homem só consegue realizar comunidades restritas ao tempo e ao espaço na qual ele realiza suas ações concretas no mundo. "Toda a espécie de seres racionais está objetivamente determinada, na ideia, a saber, ao fomento do sumo bem comunitário" (KANT, 2008, p. 103).

A determinação, o imperativo que determina a realização do sumo bem comunitário no mundo é meramente abstrato. É uma ideia limite, que os homens, enquanto tais, só conseguem entender a partir de uma comunidade efetivamente sensível no mundo, que Kant vai chamar de religião visível ou Igreja visível. "Por consequência, no esforço do homem em vista de uma 
comunidade ética, a fé eclesial precede naturalmente à fé religiosa pura" (KANT, 2008, p. 112).

É por meio de uma religião visível que se pode compreender a ideia de uma religião pura e não antes ${ }^{52}$. A ideia da lei moral diz que os homens precisam erigir uma comunidade ética universal, mas os homens só conseguem erigir comunidades restritas ao tempo e ao espaço no qual eles vivem fazendo alianças que são restritas. Isso por dois motivos: primeiro, porque a ideia de uma comunidade universal só se torna clara na sensificação de uma Igreja em si; segundo, porque o agente moral não tem forças próprias individuais para realizar essa comunidade universal sozinho. Por isso, então, aparece a ideia de Deus. "Instituir um povo de Deus moral é, portanto, uma obra cuja execução não se pode esperar dos homens, mas somente do próprio Deus" (KANT, 2008, p. 106).

Como o homem não pode realizar isso que só Deus realiza, o que ele deve fazer, então, é se reunir com outros agentes morais. Assim, a forma de o homem contribuir para a realização do sumo bem comunitário no mundo é tentando ao máximo possível sensificar essa comunidade ideal no mundo, porque é assim que os homens conseguem realizar o seu dever. A lei que comanda não é uma lei estatutária, é a lei da razão. E se uma comunidade religiosa visível elevar esse status da lei ao ponto de ser impossível

\footnotetext{
$5^{2}$ Apesar de Kant apontar que "moralmente deveria ser o inverso". Mas, mais uma vez aqui vemos o elemento antropológico. "Contudo, por causas da necessidade natural de todos os homens de, para os supremos conceitos e fundamentos da razão, exigir sempre alguma apelo sensível, alguma corroboração empírica e quejandos (a que, de fato, importa atender no intento de introduzir universalmente uma fé), deve utilizarse qualquer fé eclesial, que em geral encontra-se diante de si” (KANT, 2008, p. 115).
} 


\section{$\varphi \quad$ Filosofia, Engajamento e Sociedade}

essa repercussão moral, essa religião perde o seu valor do ponto de vista prático.

Kant está chamando de verdadeira uma Igreja visível, porque a Igreja invisível míngua na mão dos homens. No entanto, ela vigora como um ideal de orientação da Igreja visível, estabelecendo princípios que servem como determinação de um estatuto orientado para um ideal maior.

Por fim, é de destacar que uma religião verdadeira do ponto de vista daquela que é visível representada sensivelmente no mundo, vai precisar de estatutos para poder agir por determinados princípios sadios. "As leis civis estatutárias não podem, sem dúvida, chamar-se mandamentos divinos, mas se são justas, a sua observância é simultaneamente um mandamento divino" (KANT, 2008, p. 105). Isso significa que esses estatutos, esses códigos, que possuem valores meramente contingentes, na medida em que se referem às ideias morais se tornam universais. Precisamos de símbolos para entender as coisas, mas eles deixam de ser meramente símbolos arbitrários, na medida em que de fato possam se referir a algo moralmente útil. Kant mais uma vez usa o elemento antropológico. Por causa da "debilidade da natureza humana", o ser humano não consegue estabelecer uma Igreja absoluta genuína, mas enquanto ser humano, ele estabelece essa Igreja dentro dos seus limites. No entanto, mesmo dentro de seus limites, se estabelecida de forma sadia, essa religião também pode ser tida como uma religião verdadeira. "A verdadeira Igreja (visível) é aquela que de fato representa o reino (moral) de Deus na terra" (KANT, 2008, p. 107). Ou seja, se a religião histórica realmente representa o reino de Deus na terra, na medida em que tem como seu princípio fundamental o princípio sadio da moralidade, ela pode ser chamada de 
religião verdadeira, não porque ela é em si mesma uma religião verdadeira, mas porque tudo o ela faz ou se remete a fazer se refere à única religião verdadeira, que é religião pura da razão. Essa sim, de fato, é a verdadeira religião53.

\section{A crítica à religião e ao falso culto}

No quarto capítulo de seu escrito, Kant faz uma crítica severa ao clericalismo, esses que se acham os porta-vozes de Deus e impõem às pessoas as práticas mais absurdas do ponto de vista moral, visando o poder. "O clericalismo é, pois, a constituição de uma Igreja enquanto nela reina um culto feiticista [...] onde os princípios da moralidade não constituem a base e o essencial, mas sim mandamentos estatutários” (KANT, 2008, p. 181).

Para Kant, uma religião que se preze tende a cada vez mais se afastar dessa autoridade monárquica para assumir por si mesma as leis do evangelho, as leis morais. É por isso que ele fala que tal religião não é nem monárquica e nem aristocrática. Ele está pensando numa organização que cada vez mais dilua o centralismo doutrinário para conceder cada vez mais, na medida do possível, a liberdade moral das pessoas nessa comunidade.

Se este impõe a submissão obediente a um estatuto forçado, como serviço forçado, mas não a homenagem livre que deve ser rendida supremamente à lei moral, [...] trata-se sim sempre de uma fé feiticista pela qual a multidão é regida e privada de sua liberdade moral mediante a

53 Kant explica que, por mais que possa haver múltiplos de fé, há, no entanto "[...] somente uma verdadeira religião". "Pode [...] acrescentarse que nas diversas Igrejas separadas umas das outras pela diversidade dos seus modos de crença é possível deparar com uma única e mesma religião verdadeira" (KANT, 2008, p. 114). 


\section{$\varphi \quad$ Filosofia, Engajamento e Sociedade}

obediência a uma Igreja (não é religião) (KANT, 2008, p. 182).

Kant mostra que na religião não se pode centralizar o poder, porque, dessa forma, haveria uma contradição com a ideia de liberdade, que é produzir autonomia de ação nas pessoas. Assim, se uma comunidade que representa o reino de Deus na terra quer se fazer enquanto tal, ela precisa garantir primeiramente a autonomia das pessoas, para que elas possam por si mesmas saber do cumprimento do seu dever, não se submetendo, apenas, à ordem de um líder religioso para isso. Kant acusa os líderes religiosos de inspirar os praticantes a adotarem cada vez mais enunciados contrários aos da fé racional. Além disso, submetem esses praticantes aos seus falsos ensinamentos, não os deixando nem sem quer questionar tais práticas. Todos esses rituais e práticas religiosas não fundamentadas na razão, geram prejuízo à moralidade do homem e o culto falso se instala no momento em que a fé estatutária não se subordina à fé racional. "Mas aquele em que a fé revelada deve preceder à religião é o pseudo-serviço, pelo qual a ordem moral é invertida, e o que não passa de meio é incondicionalmente imposto (como se fora um fim)" (KANT, 2008, p. 167). Isso se dá porque os conteúdos da religião positiva, que apenas seriam um meio para transmitir os conceitos morais, são tratados como fins em si mesmos, causando todo tipo de superstição e fanatismo. Então, é sob a legitimação de que a religião estatutária não desempenha e não admite o seu verdadeiro papel que Kant realiza sua crítica, pois, aqui, as práticas exteriores substituem a verdadeira fé.

Pode-se notar que o mal radical afeta também a Igreja e a inversão da ordem moral na religião gera o que Kant 
chamou de falso culto. "Por pseudo-serviço (cultus spurius) entende-se a persuasão de servir alguém mediante ações que, de fato, fazem recuar seu intento" (KANT, 2008, p. 155). Isso significa que o modo de como o homem pensa agradar Deus, na verdade o faz recuar do modo como Deus verdadeiramente quer ser agradado. "Tudo o que o homem, além de uma boa conduta, imagina poder ainda fazer para se tornar agradável a Deus é simples ilusão religiosa [...]" (KANT, 2008, p. 172). O falso culto se relaciona com o mal radical porque está vinculado a uma inversão na qual o homem julga ser agradável a Deus por meio de rituais, cultos e todo tipo de exterioridades que são priorizadas em face de uma conduta moralmente boa. Spinelli (2012, p. 143) explica que "[...] há, portanto, uma sobreposição da exterioridade e da manifestação sensível perante a intenção e o cultivo da moralidade". Kant denuncia os religiosos que trocam a fé moral por uma fé meramente dogmática. Ele chama de religião revelada "[...] aquela em que eu devo previamente saber que algo é um mandamento divino para o reconhecer como dever" e de religião natural "[...] aquela que de antemão devo saber que algo é dever antes de o poder considerar como mandamento divino" (KANT, 2008, p. 156).

Assim, vê-se que, para Kant, o modo de saber se uma religião é verdadeira ou não é observando se o seu princípio essencial é, em primeiro lugar, o principio moral no qual o homem deve primeiro saber o seu dever antes de considerálo como mandamento divino. Dessa forma, as religiões, apesar de suas divergências, possuem um valor religioso que não está em seus estatutos, simbologias e revelações, mas essencialmente no valor que pode ser promulgado com as outras religiões, que pode ser, inclusive, padrão no convívio desses diversos credos. 


\section{$\varphi \quad$ Filosofia, Engajamento e Sociedade}

Por isso, o que Kant chama de religião natural enquanto religião moral é aquela que está relacionada com o efeito para o seu fim último, qual seja, o conceito de Deus como autor moral. Esse é o remédio contra o falso culto e contra a corrupção moral religiosa. É preciso tomar esse conceito racional prático puro de que todo homem pode se convencer praticamente de modo suficiente e exigir como dever o efeito dele a quem quer que seja. Esse é o grande requisito da verdadeira Igreja, a saber, "[...] a qualificação para a universalidade, enquanto por tal se entende a validade para todos, isto é, a unanimidade universal" (KANT, 2008, p. 159). Por isso, então, nota-se que, desde que bem direcionada, a fé revelada pode contribuir em prol da moralidade. Spinelli (2012, p. 144) explica que "Kant não condena a religião revelada como a única causa do falso serviço", pois a religião é um produto humano. O que Kant condena é a supervalorização do culto estatutário e seus símbolos sem se entender que eles precisam remeter a conceitos universalmente válidos.

No entanto, os conceitos são universais e os homens são seres sensíveis situados num tempo e espaço no qual se formam. Esse tempo e espaço, por sua vez, são determinados pelos limites culturais desse ambiente. Esses limites culturais geram a desunião, porque é exatamente quando cada religião se prende apenas aos seus limites culturais, sem entender que os seus símbolos deveriam remeter a algo superior, que a confusão religiosa acontece. É o que Kant chamou de "[...] fio condutor da consciência moral em matéria de fé" (KANT, 2008, p. 187). Por falta dessa consciência, as diversas religiões com seus símbolos particulares não conseguem, digamos assim, dar as mãos, porque estão meramente pautadas nas suas representações culturais. Por exemplo, como pode um politeísta concordar 
com um monoteísta se seus óculos culturais são tão diferentes? Tanto um como outro compõem sua comunidade em si e o que gera a desunião entre eles é exatamente o limite cultural de cada religião.

Por isso, Kant mostra que o mais importante é saber como "[...] ela [a consciência moral] poderá servir de fio condutor nas mais delicadas decisões morais" (KANT, 2008, p. 187), pois, invés de colher aquilo que é mais fundamental, que é o princípio moral, essas religiões se prendem, apenas, aos seus símbolos particulares.

Então, quando tentam falar de um princípio universal como a lei moral, essas religiões se utilizam de simbologias particulares. O resultado disso é uma total desunião dessas comunidades, porque ambas querem estabelecer o moralmente bom como seu fundamento baseando-se apenas nas suas representações sensíveis. Assim, o que impede que essas religiões se deem as mãos e consigam caminhar juntas no fomento da ideia moral, não é o essencial delas, ou seja, não é a religião pura. A religião nada tem a ver com essas simbologias. O que impede que essas religiões se deem as mãos são exatamente os limites culturais de cada uma delas. Elas erigem como fundamento das ações dos seus agentes apenas os conteúdos das suas representações simbólicas e deixam de entender que essas representações teriam que remeter ao que é mais fundamental, ao mais essencial, que é o mandamento da unidade universal entre os diversos credos dessas comunidades sensíveis.

Por isso Kant afirma que "Ora, como toda fé é histórica e fenomênica, acontece que resta sempre a possibilidade de aí deparar com um erro, por conseguinte, há uma ausência de consciência moral" (KANT, 2008, p. 188). O que separa essas comunidades éticas sensíveis é 


\section{$\varphi \quad$ Filosofia, Engajamento e Sociedade}

essa falta de consciência moral no entendimento das suas representações particulares. E isso se dá exatamente por causa das condições humanas que são limitadas antropologicamente. Ou seja, ao modo como os seres humanos são formados, a linguagem na qual foram formados e o modo que como construíram suas vidas. Isso mostra que, de certa forma, Kant valorizou a condição histórica de cada ser humano. Isso fica mais evidente quando ele mostra que é impossível para o ser humano compreender os conceitos sem transformá-los em símbolos, quer sejam religiosos quer não54. Mas ao eleger esses símbolos, mancha-se a pureza da lei moral, que num sentido prioritário orienta a formação desses símbolos, e o que acontece, então, é a mistura de elementos culturais com universais. Por isso, o que tem de ser mais relevante e o mais fundamental é o elemento universal, que é a ideia do divino enquanto um ser moral que não está restrita ao tempo e ao espaço como está a religião estatutária. Kant entende que

Contudo, já que uma Igreja erigida sobre leis estatutárias só pode ser a verdadeira Igreja na medida em que contém em si um princípio de avizinhamento incessante da fé racional pura (como aquela que, quando é prática, constitui em rigor, em toda fé, a religião), e pode com o tempo prescindir da fé eclesial (segundo o que nela é histórico) poderemos estabelecer nestas leis e nos funcionários da Igreja nelas fundada um serviço (cultus) eclesial na medida em que orientam em qualquer altura as suas doutrinas e ordenamento

54 Para que fique claro, cito mais uma vez a passagem em que Kant mostra que é "[...] por causa da necessidade natural de todos os homens, para entender os supremos conceitos e fundamentos da razão, exigir [...] sempre algum apelo sensível” (KANT, 2008, p. 115). 
para aquele fim último (uma fé religiosa pura) (KANT, 2008, p. 155).

Kant mostra que a verdadeira Igreja deve manter um "avizinhamento" com a fé puramente racional e de pouco a pouco ir se livrando dos conteúdos estatutários da religião positiva para, enfim, reinar a pura religião da razão. Somente assim pode-se estabelecer um serviço eclesial que orienta o homem para fins racionais. Isso se dará na medida em que os envoltórios simbólicos da religião positiva, que servem apenas de meio, forem substituídos gradualmente pela religião da razão.

Sobre isso, por fim, é de se destacar aqui a posição de Habermas sobre o aspecto semântico da religião. No texto A fronteira entre fé e saber, Habermas mostra que seu interesse na filosofia da religião de Kant diz respeito à questão de saber se é possível se livrar do conteúdo semântico da tradição religiosa sem comprometer a relação entre fé e saber. "Meu interesse na filosofia religião, de Kant, toma como orientação a seguinte questão: é possível apropriarmo-nos da herança semântica de tradições religiosas sem borrar os limites que separam os universos entre fé e saber" (HABERMAS, 2007, p. 238). Habermas entende que a deficiência teórica da pura fé da razão pode ser compensada com um interesse da razão prática nas sugestões e estímulos provenientes de doutrinas da fé transmitidas historicamente, "[...] que podem contribuir mais ou menos para tal processo". Nota-se que, dessa forma, a religião revelada possui um papel propedêutico para religião da razão, pois mesmo que a revelação tenha uma doutrina de fé contingente e não essencial, ela não é supérflua ou desnecessária. Kant não exclui as crenças da fé eclesial, mas só as considera na medida em que sejam 


\section{$\varphi$ Filosofia, Engajamento e Sociedade}

apresentadas de formas compatíveis com a genuína religião moral.

\section{CONCLUSÃO}

Na tentativa de oferecer uma reflexão sobre o papel da religião, busquei com este trabalho analisar a ideia kantiana da religião não como meramente uma união de pessoas com um credo comum, mas como devoção ao melhoramento moral. Destaco agora aqui, à guisa de conclusão, o que entendo ser o mais representativo para essa reflexão, o que obviamente tem como pressuposto o desenvolvimento de toda a argumentação exposta no texto.

Ao tomar a lei moral como máxima fundamental o homem é introduzido no caminho do bem, mas isso não significa que o homem seja plenamente moral. Significa dizer que suas potências interiores perante sua intenção moral foram restabelecidas no seu lugar fundamental, ou seja, significa dizer que o princípio moral foi colocado no patamar hierárquico no qual ele merece estar. Isso se dá porque o princípio moral foi hierarquicamente invertido e o amor próprio passou a ser o motivo dominante das ações. $\mathrm{Na}$ conversão moral, no entanto, o homem estabelece o princípio moral como máxima de suas ações. Mas, apesar de ter estabelecido o princípio moral como máxima das ações, essas ações jamais serão totalmente adequadas ao comando da lei e aqui ou acolá o ser humano se desviará do princípio moral. Por isso, ele precisa estar em constante reforma gradual que terá de buscar durante toda a sua vida. Aqui são precisas duas coisas: primeiro um exemplo de boa conduta moral e, segundo, uma sociedade que contribua moralmente para essa reforma.

O mais desregrado de todos os homens, quando está diante de um ser humano moralmente bom, têm suas 
armas lançadas abaixo, no sentido de que ele ou vai sentir ódio por essa pessoa, devido à sua grandiosidade que não pode ser vendida como a dele, ou ele vai se converter diante de um fenômeno como esse. Não exatamente por causa da vigência sensível que ele está vendo, mas porque fortalece dentro dele o móbil moral por meio do exemplo. Tal tipo de exemplo é o arquétipo do bom princípio representado pela figura de Cristo. No entanto, um dos fatos mais relevantes da reforma moral é que para que ela se desenvolva como deveria se desenvolver, é necessário um estado de sociedade sadio, que Kant chamou de comunidade ética. Essa comunidade sob a legislação moral divina, na medida em que não é objeto de nenhuma experiência sensível se chama Igreja invisível. Ela serve de arquétipo às Igrejas fundadas pelos homens, que, por sua vez, devem tomar a Igreja invisível como modelo e concordar com ela. Por isso, essa Igreja visível não pode esgotar o significado dos seus símbolos neles mesmos, mas, mesmo uma religião verdadeira do ponto de vista daquela que é visível representada sensivelmente no mundo precisa de estatutos para poder agir por determinados princípios sadios. No entanto, isso não significa que esses estatutos, esses códigos, tenham valores meramente contingentes, pois, na medida em que se referem às ideias morais, se tornam universais. Isso significa que precisamos de símbolos para entender as coisas, mas eles só deixam de ser arbitrários na medida em que se referem de fato a valores morais. Para Kant, não temos nenhuma referência sensível ao mundo divino. No entanto, devemos tomá-lo como ideal a ser atingido na realização da comunidade ética no mundo, mas o horizonte cultural nos limita, se for comparado ao horizonte universal que é necessário para a realização dessa comunidade ética universal. Esse horizonte cultural nos 


\section{$\varphi \quad$ Filosofia, Engajamento e Sociedade}

torna limitados e nos deixa presos aos símbolos que pertencem a esse determinado contexto particular. O que se tem, então, é que pensamos agradar a Deus com essas coisas, mas não percebemos que é quando obedecemos ao nosso dever para conosco e para com os homens que estamos sendo agradáveis a Deus. Então, quando cumprimos os mandamentos, os estamos cumprindo para nós e para os outros e não para Deus. Deus não precisa que sejamos santos ou pratiquemos algo para que ele seja satisfeito. Ele já é satisfeito em si mesmo. São interpretações antropomórficas a respeito de Deus que nos fazem acreditar, por exemplo, que se pode agradá-lo por meio de rituais. Daí vem a ideia de que se convenceria o divino a partir de uma pratica religiosa intensa, como se houvesse possibilidade de se abstrair de uma conduta moralmente boa para isso.

Nota-se aqui a tendência kantiana de dissolver a religião na moralidade. Kant interpreta a religião pura a partir da religião revelada. As duas estão em dois círculos concêntricos, no qual a religião da razão está no círculo mais restrito. Isso se dá porque a revelação pode pelo menos compreender também em si a religião racional pura, mas a religião pura não pode conter o elemento histórico da religião revelada. Por isso, a religião revelada está numa esfera maior. Então, e esse é o ponto principal desta conclusão, pode-se partir de qualquer religião revelada e, abstraindo da religião racional pura, considerá-la moral, mas de modo fragmentado, observando sempre se ela remeterá a conceitos morais. Se assim for, pode-se dizer que entre a razão pura e a fé revelada existe, potencialmente, não só uma compatibilidade, mas também uma harmonia, de forma que quem segue uma segue também a outra. Dessa forma, o que se tem é uma 
reciprocidade entre a religião revelada e a religião da razão, o que possibilita uma interpretação racionalizante dos dogmas da religião. Essa interpretação pressupõe uma afinidade entre o princípio intemporal, racional, e a realidade histórica da religião. Essa afinidade acaba por se tornar a base de uma hermenêutica filosófica resgatadora de conteúdos religiosos que se constitui como esperança contra o mal radical.

\section{REFERÊNCIAS}

CAPITANI, R. "A disposição originária para o bem: uma leitura semântica d'a Religião nos limites da simples razão em Kant”. Intuitio, Porto Alegre, v. 1, n. 1, jun. 2008, p. 418.

FERRAZ, C, A. Do Juízo Teleológico como Propedêutica à Teologia Moral em Kant. Porto Alegre. Edipucrs, 2005.

JORGE FILHO, E. J. "A possibilidade de uma comunidade ética e a co-responsabilidade ética em Kant”. Síntese, Belo Horizonte, v.26, n. 84. 1999, p. 87-105.

HABERMAS, J. A fronteira entre fé e saber. In: Entre Naturalismo e Religião. Trad. Flávio Beno Siebeneichler. Rio de Janeiro: Templo Brasileiro, 2007.

HERRERO, F, J. Religião e história em Kant. Trad. José A. Ceschin. São Paulo: Loyola, 1991.

HÖFFE, O. Immanuel Kant. Trad. Christian Viktor Hamm e Valério Rohden. São Paulo: Martins Fontes, 2005. 


\section{$\varphi$ Filosofia, Engajamento e Sociedade}

HECK, J. N. "O princípio do amor próprio em Kant". Síntese, Belo Horizonte, v. 26, n. 85, dez. 1999, p. 165-186.

KANT, I. Antropologia de um ponto de vista pragmático. Trad. Clélia Aparecida Martins. São Paulo: Iluminuras, 2006.

. A Religião nos limites da simples razão. Trad. Artur Mourão. Lisboa: Edições 70, 2008.

. Fundamentação da metafísica dos costumes.

Trad. Paulo Quintela. Lisboa: Edições 70, 2011.

. Crítica da Faculdade do Juízo. Trad. Valério Rohden e António Marques. $3^{\text {a }}$ ed. Rio de Janeiro: Forense Universitária, 2012.

. Crítica da Razão Pura. Trad. Manuela Pinto dos Santos e Alexandre Fradique Morujão. $8^{\mathrm{a}}$ ed. Lisboa: Calouste Gulbenkian, 2013.

. Prolegômenos a qualquer metafísica futura que possa apresentar-se como ciência. Trad. José Oscar de Almeida Marques. São Paulo: Estação Liberdade, 2014.

. Crítica da Razão Prática. Trad. Valério Rohden. São Paulo: Martins Fontes, 2015.

KRASSUSKI, J. A. Crítica da religião e sistema em Kant: um modelo de reconstrução racional do cristianismo. Porto Alegre: Ediprus, 2005. 
LIMA VAZ, C, H. Introdução á Ética filosófica I. São Paulo: Edições Loyola, 2015.

LUCHI, J. P. “Articulações de uma experiência supramoral a partir da filosofia da religião de Kant”. Sofia, Vitória, v.1, n. 1, ago./dez. 2012, p. 54-80.

LOPARIC, Z. Natureza humana como domínio de aplicação da religião da razão. In: Kant e o Kantismo. São Paulo: Brasiliense, 2009.

MEIRELLES, A, F. O esquematismo analógico na religião nos limites da simples razão. In: Kant e o kantismo. São Paulo: Brasiliense, 2009.

NODARI, P, C. A teoria dos dois mundos e o conceito de liberdade em Kant. Caxias do Sul: Educ, 2009.

PAVÃO, A. "Filosofia da religião e mal radical em Kant". Kant e-Prints. Campinas, série 2, v. 2, jul./dez. 2007, p. 171-179.

. "O moralmente bom e o moralmente mau em Kant: uma discussão com Zeljko Loparic”. Kant e-Prints. Campinas, v. 5, n. 3, jul./dez. 2010, p. 109-131. . O mal moral em Kant. Curitiba: CRV, 2011.

PINHEIRO, L, M. O conceito kantiano de intenção $<$ Gesinnung $>$ em "Sobre o mal radical na natureza 


\section{$\varphi \quad$ Filosofia, Engajamento e Sociedade}

humana”. Revista Portuguesa de Filosofia. T. 61, Fasc. 3/4, Jul. - Dec., 2005, 371-378.

PASCAL, G. Compreender Kant. Petrópolis: Vozes, 2011.

WOOD, A, W. Kant. Trad. Delemar José Voltapo Dutra. Porto Alegre: Artmed, 2008.

SPINELLI, L. M. “Kant e o Sumo bem comunitário”. Ethic@. Florianópolis, v. 11, n. 1, Jun. 2012, p. 37-57.

. “A Religião nos limites da simples razão". Kant $e$ Prints. Campinas, v. 8, n 1, jan.-jun., 2013, p. 127-151.

. "Hierarquia e inversão: a tese kantiana da ordem moral dos móbiles". Princípios. Natal, v. 21, n. 35, Jan./jun. 2014, p. 227-259.

VILAR, G. El concepto de bien supremo em Kant. In: MURGUERSA, J; ARAMAYO, R. Kant depúes de Kant. Madrid: Tecnos, 1989, p. 119-133. 


\section{SOBRE}

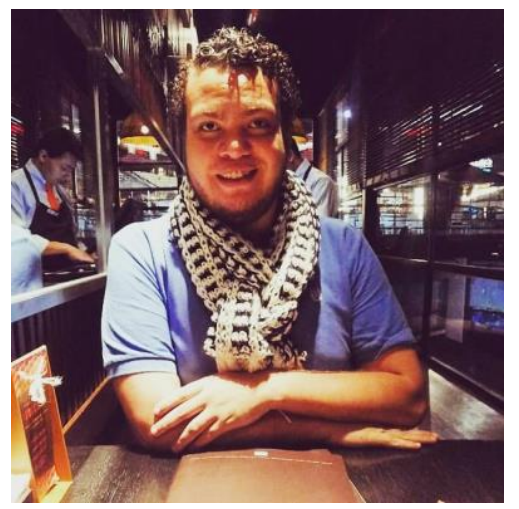

\section{Yuri Miguel Macedo} (Organizador) é Professor Pesquisador do Núcleo de Estudos Afro-Brasileiros da Universidade Federal do Espirito Santo (UFES), Professor no Programa de Pós-Graduação Lato Sensu Formação de Professores em Letras-Libras na Universidade do Estado da Bahia (UNEB), Aluno do Programa de Pós-Graduação em Ensino e Relações Étnico-Raciais da Universidade Federal do Sul da Bahia, licenciado em Pedagogia pela Faculdade de Filosofia, Ciências e Letras de Boa Esperança - FABIBE, Especialista em História e Cultura Afro-Brasileira, Especialista em Educação de Jovens e Adultos, atuando principalmente nos seguintes temas: Identidade, Cultura, Classe, Gênero, Educação Inclusiva, Educação, Devoções, Transversalidade, Africanidades e Ancestralidade. Coordenador do Grupo de Pesquisa Educação Transversal (UFES), vice coordenador do Grupo de Pesquisa Erê-Ecoa (UFES) Pesquisador dos grupos: Grupo de Pesquisas em Linguagens, Poder e Contemporaneidade - GELPOC (IFBA) ; Políticas de Inclusão e Educação para as Relações Étnico-Raciais (UFES); Invisibilidade Social e Energias Emancipatórias em Direitos Humanos (FDV) ; Espaços Deliberativos e Governança Pública (UFV/CLACSO) e Educação para as relações étnicoraciais, territorialidades e novas mídias (UFES). Membro da Associação Brasileira de Pesquisadores Negros (ABPN), Associação Nacional de Pós-Graduação e Pesquisa em Educação (ANPED) e Société Internationale d’Ergologie. 


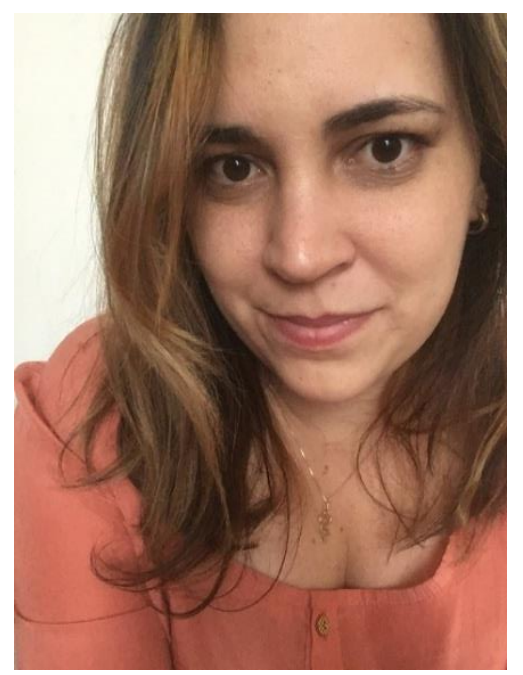

\section{Sabrina Paradizzo Senna (Prefaciadora) é Mestra em} Filosofia na área de Ética e Filosofia Política, pela Universidade Federal do Espírito Santo (UFES). É graduada em Filosofia (Licenciatura e Bacharelado), também pela UFES. Atualmente é professora voluntária pelo Departamento de Educação, do Centro de Educação, da UFES, ministrando aulas de Filosofia da Educação para turmas do Curso de Pedagogia; e também atua como professora voluntária pelo Departamento de Filosofia, do Centro de Ciências Humanas e Naturais, da UFES, ministrando aulas de Filosofia e Ética e Introdução à Filosofia para as turmas dos cursos de Ciências Contábeis, Administração, Matemática e Letras. Já atuou como professora de Filosofia do ensino médio em escolas das redes públicas e privadas de educação.

Viviane Vaz Gave é mestranda em Educação, na linha de Educação,

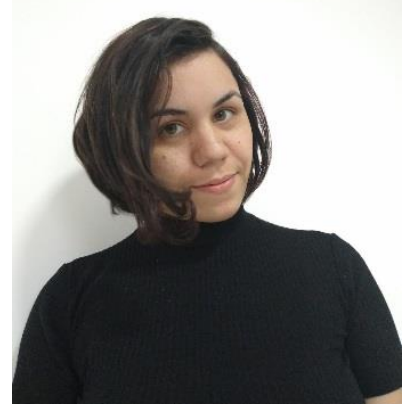
Formação e Políticas Públicas, pelo Programa de Pós-graduação em Educação da Universidade Federal do Espírito Santo (UFES). Licenciou-se em Filosofia (2018) e está graduando Pedagogia (2019) na mesma instituição (UFES). Atuou como professora de Filosofia pela Secretaria de Estado da Educação (2017) no sistema socioeducativo (IASES). Tem interesse em Filosofia Política e Filosofia da Educação. 


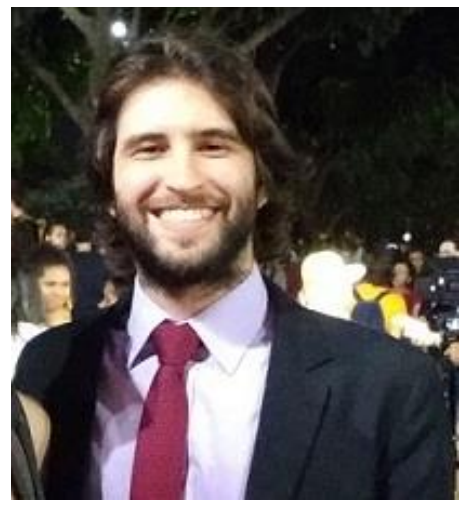

Artur Almenara Merlo Emmerich Oliveira é filósofo e advogado. Graduado em Direito pela Faculdade de Direito de Vitória (FDV), em 2016, cuja Monografia teve o título de "Uma visão foucaultiana do poder das grandes mídias na sociedade brasileira refletindo no segundo turno do processo eleitoral para presidência da república" - estudo realizado em relação ao pleito eleitoral de 2014. Já o bacharelado em Filosofia pela Universidade Federal do Espírito Santo (UFES) veio em 2018, com a apresentação da Monografia "O 18 de Brumário e a contribuição de Marx para a compreensão dos fundamentos da democracia”, sob orientação do Prof. Dr. Maurício Abdalla Guerrieri. Seu objeto de estudo atual consiste na Filosofia Política, Filosofia do Direito, Sociologia Jurídica e Epistemologia. 


\section{$\varphi \quad$ Filosofia, Engajamento e Sociedade}

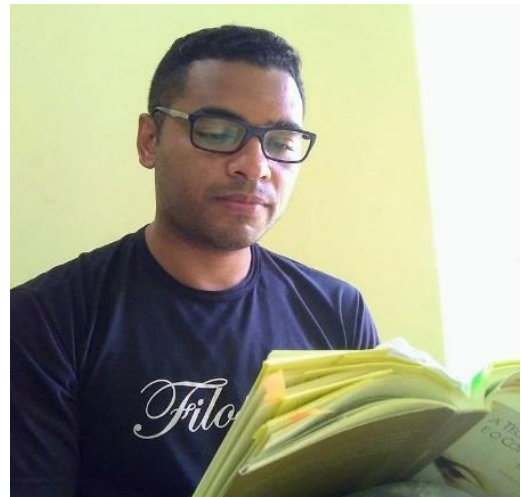

Fabrício Silva de Almeida é mestrando em Filosofia, pelo Programa de Pós-graduação em Filosofia, na Universidade Federal do Espírito Santo (UFES), com pesquisa nas áreas de Ética, Política e Religião em Immanuel Kant. É graduado em Teologia pela Faculdade Unida de Vitória-ES e em Filosofia pela UFES. Possui experiência nas áreas de Filosofia Moderna, Contemporânea, Metafísica, Ética, Política e Religião. Seus autores de interesse são: Immanuel Kant, Paul Ricoeur, Martin Heidegger, Jürgen Habermas, Michael Sandel e Nietzsche. Foi vinculado ao programa Institucional de Iniciação Científica da UFES, no período de 01/08/2015 a 31/07/2016, com o Projeto intitulado A hermenêutica filosófica da religião em Ricoeur e Kant e no período de 01/08/2016 a 31/07/2017 com o Projeto intitulado Verdade e Liberdade no pensamento de Heidegger, tendo seus resultados apresentados nas respectivas Jornadas de Iniciação Científica. 